\title{
Tax policy in the European Union : a review of issues and options
}

Citation for published version (APA):

Cnossen, S. (2002). Tax policy in the European Union : a review of issues and options. METEOR, Maastricht University School of Business and Economics. METEOR Research Memorandum No. 023 https://doi.org/10.26481/umamet.2002023

Document status and date:

Published: 01/01/2002

DOI:

10.26481/umamet.2002023

Document Version:

Publisher's PDF, also known as Version of record

\section{Please check the document version of this publication:}

- A submitted manuscript is the version of the article upon submission and before peer-review. There can be important differences between the submitted version and the official published version of record.

People interested in the research are advised to contact the author for the final version of the publication, or visit the DOI to the publisher's website.

- The final author version and the galley proof are versions of the publication after peer review.

- The final published version features the final layout of the paper including the volume, issue and page numbers.

Link to publication

\footnotetext{
General rights rights.

- You may freely distribute the URL identifying the publication in the public portal. please follow below link for the End User Agreement:

www.umlib.nl/taverne-license

Take down policy

If you believe that this document breaches copyright please contact us at:

repository@maastrichtuniversity.nl

providing details and we will investigate your claim.
}

Copyright and moral rights for the publications made accessible in the public portal are retained by the authors and/or other copyright owners and it is a condition of accessing publications that users recognise and abide by the legal requirements associated with these

- Users may download and print one copy of any publication from the public portal for the purpose of private study or research.

- You may not further distribute the material or use it for any profit-making activity or commercial gain

If the publication is distributed under the terms of Article $25 \mathrm{fa}$ of the Dutch Copyright Act, indicated by the "Taverne" license above, 


\title{
TAX POLICY IN THE EUROPEAN UNION A Review of Issues and Options
}

\author{
Sijbren Cnossen*
}

\section{INTRODUCTION}

'Determined to lay the foundations of an ever closer union among the peoples of Europe', Belgium, France, Germany, Italy, Luxembourg and the Netherlands signed the Treaty of Rome in 1957 establishing the European Economic Community. In the course of the years, another nine countries joined the Community, subsequently called the European Union (EU) following the ratification of the Treaty of Maastricht in 1992. In 2000, the EU encompassed 376 million people and generated a combined gross domestic product (GDP) of 8.5 trillion euro. ${ }^{1}$ In comparison, the United States (US) had 276 million inhabitants in that year and its GDP was 9.2 trillion euro. Accordingly, per capita income in the US (adjusted to reflect purchasing power parity) is almost 50 percent higher than that in the EU. Table 1 shows these figures as well as the percentage distribution of the EU's GDP and population and the index of per capita income per Member State.

As an economic union, the EU shares important features with the US, which is a federation. ${ }^{2}$ The economies of the EU Member States, like those of the US states, form a single integrated market free of restrictions on the movement of

\footnotetext{
*Department of Economics and Business Administration, University of Maastricht. This treatise is a revised version of my valedictory address at Erasmus University Rotterdam, delivered October 19, 2001. The updated version includes a discussion of the European Commission's Working Paper on Company Taxation in the Internal Market. The address was dedicated to Richard Bird, Charles McLure and Lans Bovenberg from whom I learn about these things. I am also grateful for the helpful comments received from Ruud de Mooij, Richard Musgrave, Judith Payne and Peter Sørensen. Of course, any remaining shortcomings are my responsibility.

${ }^{1}$ In the coming years, 10 central and eastern European countries as well as Cyprus and Malta will be admitted to the EU. The combined population of the accession countries is 106 million (28 percent of the EU's population) and the combined GDP is 409 billion euro ( 4.8 percent of the EU's GDP).

${ }^{2}$ It should be emphasized that the objectives of the Treaty of Rome and its successor go far beyond purely economic considerations. In contrast to ordinary international agreements, the Treaty established its own legal order distinct from international law and from the internal law of the Member States. The Union has legal personality and enjoys extensive legal capacity in each of the Member States. The tasks entrusted to the Union are carried out by a Parliament, a Council (consisting of representatives of the Member States varying depending upon the subject matter), a Commission (required to show complete impartiality towards the Union), a Court of Justice and a Central Bank. The acts of these institutions are binding, as they are applicable, on the Member States, their citizens and other institutions.
} 
Sijbren Cnossen

TABLE 1

European Union and United States:

Gross Domestic Product, Population and Per Capita Income, 2000

\begin{tabular}{|c|c|c|c|}
\hline & $G D P^{a}$ & Population & Per capita income \\
\hline & Euro billion & Million & Euro \\
\hline EU & $8,524.2$ & 376.1 & 22,665 \\
\hline US & $9,161.6$ & 275.6 & 33,242 \\
\hline European Union ${ }^{b}$ & \multicolumn{2}{|c|}{ Percentage distribution } & Index \\
\hline Germany & 22.9 & 21.8 & 105 \\
\hline UK & 16.0 & 15.9 & 102 \\
\hline France & 15.8 & 15.6 & 99 \\
\hline Italy & 15.6 & 15.3 & 102 \\
\hline Subtotal & 70.3 & 68.6 & 103 \\
\hline Netherlands & 4.9 & 4.2 & 115 \\
\hline Belgium & 2.9 & 2.7 & 107 \\
\hline Sweden & 2.4 & 2.4 & 102 \\
\hline Austria & 2.4 & 2.2 & 111 \\
\hline Denmark & 1.7 & 1.4 & 121 \\
\hline Finland & 1.4 & 1.4 & 103 \\
\hline Ireland & 1.2 & 1.0 & 119 \\
\hline Luxembourg & 0.2 & 0.1 & 197 \\
\hline Subtotal & 17.1 & 15.4 & 112 \\
\hline Spain & 8.7 & 10.6 & 83 \\
\hline Portugal & 1.9 & 2.7 & 73 \\
\hline Greece & 1.9 & 2.8 & 69 \\
\hline Subtotal & 12.5 & 16.1 & 79 \\
\hline Grand total & 100.0 & 100.0 & 100 \\
\hline
\end{tabular}

${ }^{\mathrm{a}} \mathrm{GDP}$ data have been adjusted to reflect purchasing power parities (PPPs).

${ }^{b}$ Within each group of Member States, ranked in decreasing order of the share of GDP in the combined GDP. Source: Author's computations on the basis of data provided by Eurostat. Figures may not sum because of rounding.

goods, obstacles to the right of establishment of businesses and employment and to the free movement of persons, services and capital. Recently, the economic union has been completed with the unification of monetary and exchange rate policies and the introduction of a single currency by 12 Member States. Furthermore, the nondiscrimination principle, closely guarded by the European Court of Justice, ensures that Member States cannot treat the nationals of another Member State, natural or juridical persons, differently from their own nationals. This principle extends to levels of public services and social protection within Member States. Although much smaller, the EU's special funds resemble similar 
federal-state transfer and grant programs in the US. The special funds mitigate the inefficiency (and inequity) that would otherwise result from the inability to provide adequate levels of public services by less-well-off Member States.

In contrast to the US, however, the EU does not have a federal government with real taxing powers and financial leverage over the Member States to mitigate adverse effects that might arise from Member State tax policies. ${ }^{3}$ The impact of these tax systems is enormous because tax levels are very high. In 2000, 3.6 trillion euro or 42.5 percent of the EU's GDP was collected in the form of tax revenue. This is 13 percentage points higher than the US tax/GDP ratio of 29.4 percent.

As economic integration within the EU progresses, the interactions between the tax systems of the Member States are of growing importance. Member State tax policies can have spillover or externality effects, positive or negative, on other Member States. Similarly, differing abilities to provide net fiscal benefits to residents may impair the efficient allocation of productive factors across Member States. Furthermore, separate tax mechanisms increase administrative and compliance complexity and costs for governments and taxpayers, and constrain Member States in pursuing redistributive tax policies.

These considerations have important implications for the design and coordination of tax systems in the EU. As background, Section II surveys tax developments in EU Member States and Section III reviews the criteria and principles that should govern the tax relationships between the Member States. Following, there are separate sections on the issues and options that Member States face when levying and coordinating their taxes on consumption (VAT and excises - Section IV), labor (income taxes and social security contributions Section V) and capital (corporation tax, individual income tax on capital income and wealth taxes - Section VI). Section VII summarizes and attempts to answer the question of how much tax systems should be coordinated between Member States.

\section{TAX DEVELOPMENTS AND EQUIVALENCIES}

As background to the discussion, this section looks at the level and composition of tax revenue systems in the EU. Overall tax levels in the EU are much higher than those in the US. This reflects the high demand for income transfers through

\footnotetext{
${ }^{3}$ The size of the EU's budget is modest, amounting to 1.2 percent of the combined GDP of the Member States. It is funded by the EU's 'own resources', i.e. contributions by the Member States, consisting of (a) customs duties, (b) agricultural levies, (c) 1.4 percent of the 'common' value added tax (VAT) base and (d) a budgetbalancing GNP-based contribution. On the expenditure side of the budget, approximately one-half is allocated to farm price support measures under the Common Agricultural Policy (CAP). A further one-third goes into five structural funds, which are, in order of importance, the Regional Development Fund, the Social Fund, the Agriculture Fund, the Cohesion Fund and the Fisheries Fund. The remainder is used for overseas cooperation, research and administration.
} 
the budget in most EU Member States. Consumption and labor, in particular, are taxed heavily. Subsequently, the broad equivalencies and differences between various taxes are clarified.

\section{Tax Developments}

\section{(a) Rising Tax Ratios}

In the past 30 years, total tax revenues, including social security contributions, ${ }^{4}$ have risen to historically unprecedented levels in all Member States, as shown in Figure 1. Tax revenue as a percentage of GDP - i.e. the tax ratio (revealing a country's preference for the size of the public sector) - for the EU as a whole increased from 33.5 percent in 1970 to 42.5 percent in 2000, or at an average rate

FIGURE 1

Tax to GDP Ratios in the EU

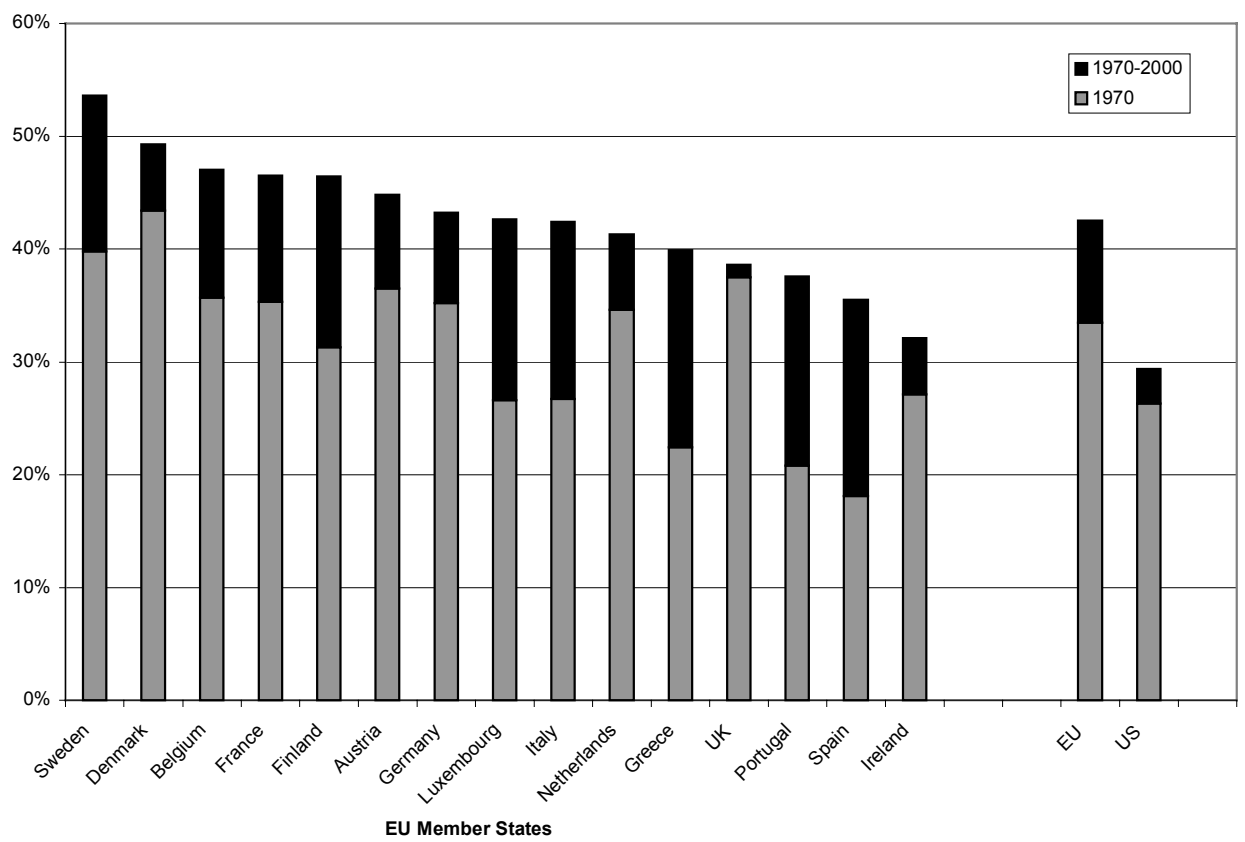

Source: Updated from Martinez-Mongay (2000).

${ }^{4}$ In line with the OECD definition, this paper treats social security contributions as taxes, because they are usually compulsory, unrequited payments to general government. All existing programs that are financed on a pay-as-you-go basis bring about substantial redistribution from the rich to the poor and/or between generations. 
of 0.8 percent per annum. ${ }^{5}$ In 2000, one in three Member States collected more than 45 percent of GDP in the form of tax revenue. In Greece, Portugal and Spain - less industrialized than most other Member States - the tax ratio was 23 percent or less in 1970, but the rate of increase since 1970 greatly exceeded those of other Member States. Overall, the figures suggest that the tax ratios of individual Member States moved closer to the EU's average. ${ }^{6}$

Basically, as pointed out in the public finance literature (Musgrave, 1969), the reasons for the high levels of taxation must be sought on the expenditure side of the budget. In most Member States, there are strong ideological commitments to high levels of social expenditure on pensions (old-age and survivors'), health services, unemployment and disability compensation, and other incomemaintenance and welfare services. In 1995, net publicly mandated social expenditure was greater than 25 percent of GDP at factor cost in Germany, Belgium, Sweden and Finland (Adema, 1999). ${ }^{7}$ Most other Member States did not trail far behind.

To finance the rising demand for social services, fundamental changes were made in the forms and methods of tax collection, which greatly lowered the marginal cost of public funds. On average, 85 percent of total tax revenue is collected not from the person who ultimately bears the tax but from employers through withholding at source (income tax, social security contributions) and from large production units (VAT, excises). ${ }^{8}$ The growth in the size of production and distribution establishments and their use of modern business accounting methods, to which the tax collection schemes can easily be attached, also assisted in raising taxes. In the early years, moreover, high economic growth rates pushed taxpayers into higher nominal income tax brackets, resulting in higher real tax payments. At times, this effect was exacerbated by inflation. ${ }^{9}$

\footnotetext{
${ }^{5}$ Figures should be interpreted with some caution. Tax ratios for 2000 are typically $1 / 2$ to over 2 percentage points lower than earlier tax ratios on account of revised GDP estimates (OECD, 2001).

${ }^{6}$ The coefficient of variation (the standard deviation divided by the unweighted average, in percent) fell from 23.6 percent in 1970 to 13.0 percent in 2000 . Broadly, the ranking in terms of total tax to GDP ratio altered little between 1970 and 2000.

${ }^{7}$ 'Net' means that the social expenditure ratios are net of income taxes, social security contributions, consumption taxes and tax breaks for social purposes. The 'clawback' of these taxes exceeds 5 percent of GDP in Denmark, Finland, the Netherlands and Sweden, but is less than 2 percent in Germany and Belgium (Adema, 1999). Italy holds an intermediate position. Comparable data on other Member States are not available.

${ }^{8}$ Whether the broad withholding tax schemes and VATs are money machines that have contributed to oversized governments, as some people believe, is difficult to say. Some may consider the reduction of the marginal cost of public funds desirable in view of a price elasticity of demand for public expenditure (including education and healthcare) greater than one (Baumol effect). On the basis of a large cross-country study, Ebrill et al. (2001) conclude that there is evidence that the presence of a VAT is associated with a higher ratio of general tax revenue to GDP. This could also be the case with wage withholding taxes and social security contributions that are collected by employers.

${ }^{9}$ For a comprehensive review of tax level and tax structure developments in the EU Member States and other OECD countries, see Messere $(1993,1998)$.
} 
Sijbren Cnossen

\section{(b) Stable Tax Mix}

Although the total tax ratio has risen sharply, the tax mix has remained remarkably stable. This is evident from Table 2, which shows the share of individual taxes in total tax revenue (indicating a Member State's preference for one tax over another) by economic category. ${ }^{10}$ Taxes on labor, nearly all withheld at source, contribute more than half of total tax revenue. What stands out, moreover, is that social security contributions by employees (one-third) and employers (two-thirds) are by far the single most important source of tax revenue. The decline in the share of taxes on consumption to about one-third is fully attributable to the decline in excise yields. Nowadays, fewer people smoke, while the real value of the (specific) alcohol excise has eroded. The averages, of course, conceal marked differences in patterns of change between Member States (OECD, 2001). Southern Member States, in particular, show a disproportionate rise in revenue from VAT and social security contributions.

TABLE 2

Tax Structure in the EU (1970-2000) and the US (2000) (weighted averages)

\begin{tabular}{|c|c|c|c|c|c|}
\hline & $\begin{array}{l}E U, \\
1970\end{array}$ & $\begin{array}{c}E U, \\
1980\end{array}$ & $\begin{array}{c}E U, \\
1990\end{array}$ & $\begin{array}{l}E U, \\
2000\end{array}$ & $\begin{array}{c}U S, \\
2000\end{array}$ \\
\hline Consumption & 38.0 & 31.6 & 31.1 & 32.6 & 15.8 \\
\hline $\mathrm{VAT}^{\mathrm{a}}$ & 16.1 & 16.3 & 17.9 & 19.3 & 7.4 \\
\hline Excises $^{b}$ & 21.9 & 15.3 & 13.2 & 13.3 & 8.4 \\
\hline Labor & 48.8 & 56.9 & 55.1 & 52.0 & 52.0 \\
\hline Income tax ${ }^{c}$ & 16.2 & 19.7 & 18.8 & 18.3 & 27.9 \\
\hline Social security contributions & 32.6 & 37.2 & 36.3 & 33.7 & 24.1 \\
\hline Capital & 13.2 & 11.5 & 13.8 & 15.4 & 32.2 \\
\hline Corporation tax & 5.3 & 5.1 & 6.5 & 6.5 & 7.9 \\
\hline Income tax & 2.8 & 2.1 & 3.2 & 3.8 & 15.0 \\
\hline Property taxes ${ }^{\mathrm{d}}$ & 5.1 & 4.3 & 4.1 & 5.1 & 9.3 \\
\hline Total & 100.0 & 100.0 & 100.0 & 100.0 & 100.0 \\
\hline
\end{tabular}

${ }^{a}$ Including revenues from pre-VAT consumption taxes and retail sales taxes in the US.

${ }^{\mathrm{b}}$ Taxes on tobacco, alcohol, petrol, motor vehicles and other specific goods and services.

${ }^{c}$ Including taxes on labor income imputed to the self-employed and payroll taxes.

${ }^{\mathrm{d}}$ Taxes on net wealth, immovable property and property transfers.

Sources: Updated from Martinez-Mongay (2000) and OECD (2001).

${ }^{10}$ The use of economic categories computed from national accounts owes much to the pioneering work of Mendoza, Razin and Tesar (1994). Their classification differs from the classification in OECD Revenue Statistics, which shows tax collections by legal categories. This has the disadvantage that tax collections for the individual income tax combine taxes on labor and capital of the self-employed. For a review and critique of the new approach, as well as various suggestions for improvement, see Volkerink (2001). 


\section{(c) High Implicit Tax Rates}

Finally, Table 3 shows the implicit tax rates (tax revenues expressed as a percentage of the potential tax base computed from national accounts) in the EU. ${ }^{11}$ Relative to the tax base - i.e. wages as computed from national accounts the rising implicit tax rate on labor to over 37 percent is highest, although the tax base itself declined relative to GDP (see the memorandum item). The implicit tax rate on consumption, at 25 percent, has remained stable throughout the period under review, although the consumption base as a percentage of GDP increased. The rise in the implicit tax rate on general consumption (VAT) was largely offset by a notable decline in the rate of tax, measured against general consumption, on specific goods and services (excises). Capital is taxed at an implicit rate of 23 percent, 14 percentage points lower than the implicit tax rate on labor.

TABLE 3

Implicit Tax Rates in the EU (1970-2000) and the US (2000) (weighted averages)

\begin{tabular}{|c|c|c|c|c|c|}
\hline & $\begin{array}{l}E U, \\
1970\end{array}$ & $\begin{array}{l}E U, \\
1980\end{array}$ & $\begin{array}{l}E U, \\
1990\end{array}$ & $\begin{array}{l}E U, \\
2000\end{array}$ & $\begin{array}{c}U S, \\
2000\end{array}$ \\
\hline Consumption & 24.9 & 22.6 & 23.8 & 25.5 & 10.2 \\
\hline VAT & 10.5 & 11.7 & 13.7 & 15.1 & 4.8 \\
\hline Excises & 14.4 & 10.9 & 10.1 & 10.4 & 5.4 \\
\hline Labor & 25.3 & 32.5 & 35.4 & 37.3 & 24.9 \\
\hline Wage tax & 8.8 & 11.4 & 12.1 & 12.9 & 13.4 \\
\hline Social security contributions & 16.5 & 21.1 & 23.3 & 24.4 & 11.5 \\
\hline Capital & 18.5 & 19.3 & 21.0 & 23.3 & 22.7 \\
\hline Corporation tax & 7.4 & 8.5 & 9.5 & 9.7 & 7.1 \\
\hline Income tax & 4.1 & 3.6 & 5.4 & 6.1 & 7.2 \\
\hline Property taxes & 7.0 & 7.2 & 6.1 & 7.5 & 8.4 \\
\hline \multicolumn{6}{|l|}{$\begin{array}{l}\text { Memorandum item } \\
\text { Tax bases as percent of GDP }\end{array}$} \\
\hline Consumption & 50.7 & 53.5 & 52.6 & 54.1 & 66.7 \\
\hline Labor & 64.3 & 67.4 & 62.7 & 59.5 & 61.5 \\
\hline Capital & 24.3 & 22.3 & 26.2 & 27.9 & 32.2 \\
\hline
\end{tabular}

Source: Updated from Martinez-Mongay (2000).

\footnotetext{
${ }^{11}$ The potential tax bases for consumption and labor can be ascertained directly from national accounts, but difficulties arise in the computation of the tax base for capital. Usually, the net or gross operating surplus of the economy is taken as the tax base. But this national accounts item is a mixed bag of various income sources that are difficult to disentangle (Nicodème, 2001)
} 


\section{Comparison with the US}

The public sector in the US is much smaller. Net current public social expenditure, at less than 18 percent of GDP, is significantly lower than in most EU Member States (Adema, 1999). By extension, the tax ratio in the US, at 29.4 percent in 2000 (Figure 1), is 13 percentage points lower than that in the EU. ${ }^{12}$ The US tax ratio, moreover, has risen at a much lower rate since 1970 - on average 0.4 percent per annum, positioning it at the same level in 2000 as the EU was at in 1967 (OECD, 2001). ${ }^{13}$ Apparently, political resistance to public spending and heavy taxes and charges, particularly regarding income transfers, is stronger in the US than in the EU. In terms of tax structure (Table 2), the US relies much more than the EU does on taxes on individual income from wages and capital. Interestingly, the implicit tax rate on capital in the US (Table 3) is almost as high as it is in the EU, but the implicit tax rates on labor and consumption are much lower.

Dwelling on the reasons for the large public sectors in the EU, political scientists, such as Webber and Wildavsky (1986) and Mueller (1997), argue that the political cultures in most Member States are characterized by the state-rulescitizen view of the polity, relatively weak market regimes and strong egalitarian influences. The prominent position of the state explains the preference for regulation and subsidization, among others of labor (after taxing it first!). The weak market regime is mirrored in the concern with large economic and social differences. But in perspective, it is probably the pervasive rise of egalitarianism, with its passion for equality of condition, that best explains the continuous increase in the size of government and the attendant rise in the tax burden. When faced with the choice, EU Member States, conditioned by the unsettling effects of two world wars and a great depression, appear to prefer equality of result over equality of opportunity, even if this means that everyone receives less than under an alternative regime.

\section{Tax Equivalencies}

The classification, made above, of the major taxes by economic category into taxes on consumption, labor and capital says little about their economic or effective as distinct from their legal or formal incidence. Taxes on one economic category, moreover, can be equivalent to some combination of taxes on the other economic categories. An understanding of these equivalencies can be helpful in

\footnotetext{
${ }^{12}$ Overall, the difference in the size of the public sectors between the EU and the US is somewhat smaller than indicated above, because social benefits are taxed more heavily in the EU. But if the difference in clawback were, say, 3 percentage points, then the difference between the tax ratios would still be 10 percentage points. This difference should be attributed mainly to differences in social security contributions (and expenditures).

${ }^{13}$ In a further analysis, of course, aspects such as the extent of tax expenditures (doing things through the tax side rather than the expenditure side of the budget), clawing back social benefits, public borrowing and the effect of the underground economies have to be taken into account in evaluating the size of the public sector.
} 
clarifying the issues and options that the EU Member States, separately and jointly, face in considering the future of their tax systems. ${ }^{14}$

In line with the sequence of economic categories adopted above, consider the following identity for a closed economy:

$$
C \equiv Y-S \equiv W+R-I,
$$

where $C$ is consumption, $Y$ is total income, composed of labor income $W$ and capital income $R$, and $S$ is saving (which equals $I$, investment). $R$ is the sum of the normal return on capital (generally, the rate of interest, adjusted for risk and inflation) and economic rents.

Any term in the identity can serve as the base for a particular comprehensive, uniform-rate consumption tax. $C$ could be the tax base for a retail sales tax. $Y-S$ represents the base for an individual consumption or expenditure tax that provides an allowance for saving. ${ }^{16}$ A tax on labor income that permits a deduction for pension contributions but taxes later payouts resembles such an individual consumption tax. This tax is found in all Member States.

The term $W+R-I$ represents value added, which forms the base for the consumption-type VAT. At business level, this value added is equivalent to the difference between sales and purchases in the profit and loss account, but calculated on a cash-flow basis - investments (including inventories) are expensed immediately (the tax is fully creditable against the tax on sales, to use VAT terminology). Thus, the VAT is equivalent not only to a tax on income net of saving but also to a tax on wages and business cash flow, $R-I$, all levied at the same uniform rate. The inclusion of business cash flow in the tax base distinguishes a consumption tax from a labor income tax.

Over time, the revenue from a tax on business cash flow comes from two sources: economic rents from past and future investments, and the normal return on capital already in place. Thus, a consumption tax is also equivalent to a combination of invariant and uniform-rate taxes on labor income, economic rents and 'old' capital. The normal return on new capital, however, is not taxed. This distinguishes a consumption tax from an income tax, which taxes saving twice by expensing new investments over their lifetime. In practice, of course, the normal return on new capital is not taxed under the income tax if interest is deductible in ascertaining profits and not taxed at the level of the recipient, such as a tax-exempt entity.

\footnotetext{
${ }^{14}$ For the following, see especially Auerbach, Frenkel and Razin (1996), who formally demonstrate, in a oneperiod model, that a tax on income is equivalent to a tax on consumption and that a tax on imports is equivalent to a tax on exports. Furthermore, the authors show that these equivalencies carry over to a multiperiod setting, provided that the tax rates are constant and that the return to new savings is not taxed.

${ }^{15}$ Usually, the entrepreneurial risk premium is considered part of the return on capital, but it can also be viewed as labor income.

${ }^{16}$ For persuasive arguments in favor of the individual consumption tax, see Meade (1978) and Bradford (1986).
} 
Sijbren Cnossen

What happens to these equivalencies in an open economy can be illustrated by the balance-of-payments identity between current and capital account:

$$
X-M+E \equiv I^{f} \quad \text { or } \quad X-M \equiv I^{f}-E,
$$

where $X$ is exports, $M$ is imports, $E$ is net earnings from abroad and $I^{f}$ is net investment abroad ( $E$ and $I^{f}$ are negative if outbound flows exceed inbound flows). By excluding exports from the base and including imports, a VAT now becomes equivalent to a tax on labor income plus a tax on domestic and foreign capital income, net of new domestic and foreign investment.

The equivalencies suggest that there is little theoretical basis for focusing nearly exclusively on the coordination of VAT and excises, as the Treaty of Rome does (as well as the WTO agreement). In principle, taxes on income and profits require coordination just as much as VAT and excises do. ${ }^{17}$

\section{PRINCIPLES AND CRITERIA FOR TAX COORDINATION}

While the US is a federation (Bundesstaat), the EU may perhaps be said to have the contours of a confederation (Staatenbund). ${ }^{18}$ The power to tax is the most important difference between these two forms of constitutional cooperation. In the EU, this power resides with the Member States, unlike in the US where the federal government has important taxing powers independent of the states. ${ }^{19}$ Thus, the political tax setting in an interdependent EU contains elements of both the 'independent nation state' and the 'federal system'. The three main criteria that may be applied to the design of tax policy in this setting are (a) jurisdiction (who should tax what), (b) distortion (how can this be done without interfering with the efficient functioning of the internal market) and (c) enforcement (how can EU-wide tax administration and compliance costs be minimized).

\section{Jurisdiction}

Jurisdiction is a central issue in the Treaty of Maastricht (1992). In the name of 'subsidiarity', the Treaty proceeds from a presumption in favor of decentralization. Basically, policy functions, including taxation, should be exercised by the Member States, although the states are obliged to consider the effects of their actions on other Member States (Smith, 1993).

\footnotetext{
${ }^{17}$ And perhaps more, because lack of coordination creates greater complexity and opportunities for tax avoidance than under VAT and excises.

${ }^{18}$ The philosophy of political integration between a Bundesstaat and a Staatenbund is quite different. In a Bundesstaat, the center and the states are each, within a sphere, coordinate and independent (Wheare, 1963). In a Staatenbund, the center is subordinate to the states and dependent on them.

${ }^{19}$ For a comprehensive analysis of the tax rules that apply between independent countries and between the constituent parts of a federation, see Musgrave (1983), McLure (2001) and Boadway (2001).
} 


\section{(a) Subsidiarity}

In taxation, subsidiarity seems to have three distinct but related dimensions.

First and foremost, subsidiarity in an interdependent EU means that Member States should cooperate to establish the rules of the tax game. Basically, these rules should have regard to the reconciliation of competing claims to the same tax base. This means that the tax bases have to be agreed upon and properly formulated. Unambiguous definitions and practices (i.e. transparency) are essential.

Secondly, and no less importantly, subsidiarity means that Member States should be able, in McLure's (2001) words, 'to control the level of revenue at the margin; that is, they must be able to set the level of taxes to correspond to the desires of voters'.

Thirdly, the Member States should be able to operate their own tax systems, designed in accordance with the agreed rules, without the need for day-to-day cooperation with other Member States in the form of information exchange, cross-border audits, etc. which infringes on subsidiarity. Operational independence means that legal concepts and practices, as well as assessment, collection and appeal procedures, should remain the prerogative of the Member States. ${ }^{20}$

Viewed together, these three features of subsidiarity suggest that tax sovereignty (as laid down in the unanimity rule for taxes) has to be ceded in establishing the tax entitlement rules so that tax independence can be exercised more fully in setting the tax rates and administering the rules.

\section{(b) Application to Tax Categories}

Traditionally, tax entitlement issues under consumption taxes (VAT and excises) have involved the choice between the destination and the origin principles. Under the destination principle, the revenue from consumption taxes accrues to the jurisdiction of final sale (a close proxy for consumption). To effect this principle, goods and services leaving a Member State (exports) are untaxed, and goods and services entering a Member State (imports) are taxed on a par with instate-produced goods and services. These adjustments are called border tax adjustments. $^{21}$

By contrast, goods and services can also be taxed on an origin basis, in the Member State of production. Revenue would then accrue to each state involved in the cross-border transaction in proportion to the value added by that state. In a

\footnotetext{
${ }^{20} \mathrm{McLure}(1992 \mathrm{a})$ is the auctor intellectualis of the operational (or, as he calls it, administrative) independence principle.

${ }^{21}$ Prior to 1993, border tax adjustments were effected through border controls administered by customs authorities. Subsequently, however, the adjustments were shifted to books of account. Currently, the tax on exports is remitted on the basis of documentary evidence and imports are implicitly taxed at the level of the first in-state trader because there is no credit for tax on imports.
} 
looser sense, exports would be taxed but imports would not. ${ }^{22}$ In tax assignment theory, the destination principle has the benefit of the doubt, because the 'generalized benefits of public services - benefits that cannot be financed by fees, charges and taxes closely related to benefits - are more closely related to where people live than to where they work' (McLure, 2001). Hence, a destination-based consumption tax would be preferable to an origin-based consumption tax.

Taxes on labor (income taxes, social security contributions) are levied on the source principle (by the Member State in which the income is earned) or the residence principle (by the Member State in which the worker resides). On the basis of McLure's rule the residence principle has the benefit of the doubt. Generally, the choice of principle is not an issue, however, because workers usually live where they earn their wages. In the case of frontier and migrant workers, tax base allocation problems tend to be solved through bilateral tax agreements. A thorny jurisdictional issue is the portability of rights to retirement income by pensioners across Member State borders. ${ }^{23}$

Taxes on capital income (corporation tax, individual income tax) are also levied on the source (territoriality) principle (by the state in which the investment is made) or the residence principle (by the state in which the supplier of capital resides). Under the source principle, the residence state exempts the income; under the residence principle, the source country exempts the income or the residence country provides a credit for the source-country tax. The source principle promotes equal treatment (nondiscrimination): residents and nonresidents face the same tax burden on an investment in a particular Member State. By contrast, the residence principle ensures equal treatment between resident individuals, regardless of where they invest. This enables residence states to tax in accordance with ability to pay, which promotes interpersonal equity within residence states.

Currently, both principles are applied in the EU (and elsewhere). Corporate profits (direct investment income) are taxed at source on the philosophy that the source state has created the economic conditions under which real investment can flourish. However, dividends, interest and royalties (portfolio income) are taxed on a residence basis (and a source basis if remittances are subject to noncreditable withholding taxes).

\footnotetext{
${ }^{22}$ The definition of the origin principle used here and by most economists differs from the meaning that the European Commission gives to it. The Commission uses the label for VAT collection in the country of supply (even if the revenue is transferred to the Member State of acquisition).

${ }^{23}$ In Germany and Luxembourg, pension contributions are paid out of taxed income, but neither investment returns nor benefits are in principle subject to tax. In Denmark, Italy and Sweden, contributions can be paid out of untaxed income, but both investment returns and benefits are subject to tax. In other Member States, neither contributions nor investment returns are subject to tax, but benefits are. For a review of the issues, see European Commission (1997).
} 


\section{Distortion}

Distortion is central to the Treaty of Rome (1957). The founding fathers believed that competition should be the mechanism for allocating economic resources in the EU. Accordingly, equal conditions for competitors should not be distorted through the tax (or expenditure) system. Generally, this requires a substantial degree of tax coordination.

\section{(a) Externality Effects ${ }^{24}$}

While this seems fairly straightforward, in a broader context various next-best issues, such as differences in product and factor mobility and the interaction effects between Member State tax policies, should be taken into account. Member State tax policies can have spillover or externality effects, positive or negative, on other Member States. Positive externalities result from greater tax base mobility, which gives rise to tax competition. Without tax coordination, this will lead to an outcome in which tax rates are lower in all Member States than they otherwise would be. The consequences are that Member State governments will perceive their marginal cost of public funds to be higher than it is from a social point of view. Hence, they will have an incentive to undertax. ${ }^{25}$ Differentiated rates, moreover, will involve an inefficient allocation of resources across the EU.

Negative externalities (which may or may not offset the incentive effects of positive externalities) occur when taxes imposed by one Member State are borne partly by residents of other Member States through, say, the exportation of a tax on natural resources. The effect of tax exporting is the opposite of tax competition. Member States now have an incentive to overtax. ${ }^{26}$ While tax competition decreases with the size of the Member State, tax exporting increases with size. Generally, competition in product and factor markets mitigates negative externalities.

Another source of inefficiency arises in the allocation of productive factors across Member States because the abilities of governments to provide net fiscal benefits (the difference between the monetary value of public goods and services obtained and the tax paid to the state) for their residents differ (Mieszkowski and Musgrave, 1999). ${ }^{27}$ These net benefits tend to be negative for high-income persons and positive for lower-income persons, but the benefits will be systematically higher in better-off states for taxpayers of a given income.

\footnotetext{
${ }^{24}$ This subsection draws on Boadway (2001).

${ }^{25}$ The effect is greater for small Member States, since their perceived elasticity of tax base due to mobility will be higher. Accordingly, small Member States will exploit large Member States by setting lower tax rates (Kanbur and Keen, 1993).

${ }^{26}$ In the EU, tax exporting is permitted, but in-state customers have to be charged the same price for, say, natural gas as out-of-state customers.

${ }^{27}$ This argument assumes that taxes are not benefit-based.
} 
Accordingly, relocation takes place on the basis of fiscal rather than economic considerations.

Whether tax competition is a bad or a good thing is to some extent in the eye of the beholder. Although tax competition skews tax structures in favor of more mobile bases and causes governments to provide lower levels of public goods than they otherwise would, it can serve as a discipline on the "profligacy of Princes' (Adam Smith, 1776) and present-day governments (Edwards and Keen, 1996). Furthermore, some tax bases are more mobile ex ante than ex post. If so, the familiar hold-up problem applies, i.e. once assets are in place, governments treat the assets as fixed and levy a high tax rate on them. Tax competition mitigates this problem (Kehoe, 1989).

\section{(b) Application to Tax Categories}

The application of the destination principle to consumption taxes does not affect relative prices between in-state- and out-of-state-produced goods and services. Early on, however, it was thought that the destination principle required border controls to effect border tax adjustments. Hence, it was proposed that the EU should shift to the origin principle, under which these controls were not thought to be required (Shibata, 1967). In the absence of factor flows, this would not have distortionary consequences. After all, the equivalence theorem (Tinbergen Committee, 1953) postulates that it makes no difference to real trade and investment which principle is applied, nor whether one principle is substituted for the other. Since imports are exchanged for exports, a tax on exports is equivalent to a tax on imports. In the event of a change from one principle to the other, compensating domestic price movements (or exchange rates) would ensure that real trade and investment are not affected.

However, the conditions for the equivalence to hold are very severe. Thus, the VAT must be truly comprehensive and the tax rate uniform. ${ }^{28}$ Such a tax has no real-world counterpart. In practice, therefore, tax base and rate differences tend to distort producer and consumer choices within and between Member States. ${ }^{29}$ Specifically, non-comprehensive destination-based taxes tend to distort consumer markets, because producers can buy their inputs free of tax (which promotes production efficiency). Similarly, non-comprehensive origin-based taxes tend to distort producer markets, because consumers can buy free of tax

\footnotetext{
${ }^{28}$ Furthermore, trade must be balanced initially. Even if these conditions are met, there would still be intergenerational wealth effects (Bovenberg, 1994). For recent studies exploring the equivalence conditions, see Lockwood, de Meza and Myles (1994) and Genser (1996).

${ }^{29}$ Obviously, health, safety and other product standards as well as subsidies can have the same distortionary effects as taxes. Moreover, as the equivalencies in the previous section suggest, a distortionary tax on goods and services can be replicated by a product-sector-differentiated profits tax.
} 
(which promotes exchange efficiency). ${ }^{30}$ In considering the choice of principle in this situation, Diamond and Mirrlees (1971) have shown that the pursuit of production efficiency as a policy objective takes precedence over the pursuit of exchange efficiency. Accordingly, the destination principle is to be preferred.

The equivalence theorem cannot be applied to the excises. Differentiated rates violate exchange efficiency and may involve substantial trade diversion, particularly between neighboring Member States. Hence, tax competition is a problem for high-taxed, low-volume goods, such as tobacco, alcohol and petroleum products. ${ }^{31}$

As in the case of the VAT, tax competition is not much of an issue for taxes on labor. ${ }^{32}$ Employees do not easily migrate to Member States with lower income taxes and social security contributions. Language is a formidable barrier, and virtually the only labor migration in the EU - very little - occurs between Member States that speak the same tongue. Generally, high-skilled labor is more mobile than low-skilled labor, but the difference is not significant. The (detrimental) efficiency effects of labor taxes manifest themselves mainly through higher product costs and lower work effort (if the substitution effect outweighs the income effect), but these costs tend to be borne mainly by the Member States themselves.

Although resident and nonresident investors face the same capital income tax burden under the source principle (capital import neutrality), the principle violates production efficiency, because pre-tax capital costs would differ between Member States if rates differ. ${ }^{33}$ The residence principle, in contrast, promotes production efficiency because all firms face the same (reduction in the) pre-tax required rate of return (capital export neutrality), provided tax credits are not limited to the home-country tax and there is no deferral. Exchange efficiency would suffer, however, because savers would face different (reductions in) posttax returns. Nevertheless, most economists agree that residence-based taxation is superior to source-based taxation, because users of capital (business firms) are

\footnotetext{
${ }^{30}$ Production efficiency is achieved when all firms face the same input prices (including the cost of capital) and all face the same price of output. Exchange efficiency is achieved when all consumers face the same product prices.

${ }^{31}$ This does not apply to motor vehicle taxes, which can be tied to taxpayers' residences.

${ }^{32}$ The economic equivalence of labor income taxes with consumption taxes deserves to be emphasized. As argued above, the incidence of consumption taxes is on labor. Similarly, labor income taxes are likely to be largely borne by workers, because the elasticity of demand for labor is considerably greater than the elasticity of supply.

${ }^{33}$ Drawing on trade theory, Slemrod (1995) argues that there is a close analogy between trade taxes and income taxes. Source-based income taxes, such as the corporation tax and withholding taxes on remittances, are akin to tariffs on inbound capital. These tariffs permit capital-importing countries to engage in 'ownership protectionism' similar to 'border protectionism' made possible by trade taxes. Residence-based taxes do not have this problem.
} 
more sensitive to tax-induced differences in return than suppliers of capital (savers). ${ }^{34}$

Tax competition is a serious problem under capital income taxation. Capital, particularly financial capital, is highly mobile. If the supply of capital at a given rate of return is perfectly elastic, then the tax on domestic capital income cannot be increased by so much that the after-tax rate of return on such income rises above the rate in other countries. ${ }^{35}$ Capital owners would simply move their capital to those other countries (unless country-specific rents exist). Also, it is difficult to pass the capital income tax on in product prices that are determined on world markets. Thus, in the long run, taxes on capital at rates higher than those prevailing elsewhere must be borne by suppliers of relatively immobile factors, e.g. labor and land.

\section{Enforcement}

The problem of enforcement is important in its own right. Agreements on the issues of distortion and jurisdiction come to naught if they cannot be implemented properly in a manner that enhances the mutual trust of Member States.

Under consumption taxes, the origin principle is more difficult to administer than the destination principle because it involves transfer pricing issues (Cnossen, 1983). If exports are taxed and imports are not taxed, business firms in high-tax states have an incentive to undervalue sales to out-of-state affiliates and to overvalue purchases from out-of-state affiliates. ${ }^{36}$ Also, under a tax-credit type of VAT, some notional tax credit would have to be attached to imports to prevent them from being taxed in in-state stages of production or distribution.

The enforcement of taxes on labor income is not much of a problem. Generally, these taxes are withheld at source by employers in the residence state of workers.

The source principle and the residence principle are both difficult to enforce under taxes on capital income. The source principle requires separate accounting per Member State on an arm's-length basis. Theoretically, this is impossible to implement between related corporations; hence various ad hoc and therefore contentious arrangements must be made. Differences in tax rates, moreover, provide an incentive to business firms to shift profits by manipulating transfer

\footnotetext{
${ }^{34}$ Horst (1980) has shown that if the elasticities of supply and demand for capital are positive but finite, the optimal tax lies somewhere between the point that ensures capital export neutrality and the point that conforms to capital import neutrality. For a comprehensive review of the studies on the choice between the residence and source principles, see US Department of the Treasury (2001, ch. 3).

${ }^{35}$ Exceptionally, large countries can export part of capital income taxes, because their capital flows are large enough to affect the rate of return in smaller countries. The large-country phenomenon would also apply to the $\mathrm{EU}$ as a whole.

${ }^{36}$ Note that transfer pricing issues would arise even if rates were uniform across the EU, because governments would still be interested in taxing as much of the base originating in their state as possible.
} 
prices (prices charged to or by out-of-state affiliated corporations) and by using excessive debt finance (thin capitalization), because interest is deductible in ascertaining taxable profits and may not be taxed at the level of the (nonresident) recipient. The implementation of the residence principle faces even greater technical, legal and political difficulties (Keen, 1993; Tanzi, 1995). Profits would have to be taxed on a current basis with full credit for taxes paid elsewhere. This makes residence states hostage to the taxes levied by source states.

\section{Conclusions}

This brief review of the tax principles and criteria that should guide tax coordination within the EU clearly shows that trade-offs must be made. While tax subsidiarity generally requires that each Member State should be permitted as much tax independence as is commensurate with the goals of free trade and free competition, fiscal neutrality, on the other hand, implies a substantial degree of tax coordination. ${ }^{37}$ So does tax enforcement.

Few trade-offs have to be made under VATs levied under the destination principle. This principle promotes subsidiarity (rate differences can be accommodated if the tax base has been agreed to), production efficiency and enforcement. Excises need to be more closely coordinated if trade is not to be diverted to low-tax Member States. Coordination, however, violates the subsidiarity requirement. Taxes on labor income involve few jurisdictional and externality problems. Perhaps most problems arise in the taxation of capital income, which is highly mobile. The dilemma is best summed up by Slemrod (1995a), who believes that 'although it is not desirable to tax capital income on a source basis [because source-based taxes are distortionary], it is not administratively feasible to tax capital on a residence basis'.

The principles and criteria developed above form the basis for a closer evaluation of the taxes on consumption, labor and capital in the following sections.

\section{TAXES ON CONSUMPTION}

The founding fathers of the European Economic Community, the EU's predecessor, believed that the elimination of import duties, completed on

\footnotetext{
${ }^{37}$ See Cnossen (1990). Although interacting, distortion and jurisdiction are distinct problems. Distortion would still arise if all the revenues from different tax systems were collected by one EU-wide tax administration. Jurisdiction would still be an issue if tax structures and rates were the same in all Member States, because the various taxing authorities would still compete for revenue.
} 
January $1,1968,{ }^{38}$ would not be sufficient to achieve the goals of free movement of goods and services and undistorted competition if cascade-type turnover taxes (levied in five out of the six original Member States) and excises were allowed to function as trade barriers instead. ${ }^{39}$ The European Commission set up by the Treaty of Rome was instructed, therefore, to formulate proposals for the harmonization of these taxes in the interest of the Common Market. ${ }^{40}$ This led to the EU-wide introduction of the VAT. Subsequently, the adoption of the VAT became a nonnegotiable condition for membership. By contrast, harmonization proposals for the excises have made little or no progress.

\section{Value Added Taxes}

In 1977, the base and workings of the VATs in the EU were substantially harmonized through the adoption of the Sixth Directive (Directive 77/388/EEC). Subsequently, with the abolition of border controls in 1992, a transitional regime (in the absence of some definitive regime) or deferred payment system was introduced, dealing with the treatment of intra-EU supplies (exports) and acquisitions (imports) (Directive 91/680/EEC). In conjunction with the new regime, a VAT Information Exchange System (VIES) was set up to monitor the VAT on the supply and acquisition of goods (not services) from other Member States. Finally, rate approximation (a minimum standard rate of 15 percent and a minimum reduced rate of 5 percent) was agreed upon to reduce perceived crossborder-shopping incentives following the removal of border controls (Directive 92/77/EEC).

Against this background and a survey of current VATs in the EU, the following questions come to mind. Has the Sixth Directive, promulgated 25 years ago, withstood the ravages of time, particularly as regards the

\footnotetext{
${ }^{38}$ In addition, various nontariff barriers having equivalent effect had to be removed. Examples are different product regulations and standards for health or safety reasons or for environmental or consumer protection. Most of these barriers lingered until 1992.

${ }^{39}$ Cascade-type turnover taxes were levied on sales every time a product changed hands, without regard to the tax levied in previous stages of production and distribution. Hence, these taxes became cumulative and capricious in their effects on prices and they induced firms to integrate. More importantly, refunds upon export could not be calculated precisely and nor could compensating taxes on imports. By implication, the refund and compensating tax mechanisms (border tax adjustments) could be used for protectionist purposes.

${ }^{40}$ Article 95 (old) of the Treaty of Rome prescribes that 'no Member State shall impose, directly or indirectly, on the products of other Member States any internal taxation of any kind in excess of that imposed directly or indirectly on similar domestic products'. Article 99 (old) therefore placed a mandatory call upon the European Commission to formulate proposals for the harmonization of sales taxes and excises in the interest of the Common Market. In the early 1960s, the Commission set up two committees (Neumark Committee, 1963; Jansen Committee, 1963), which both recommended the EU-wide adoption of the VAT already in place in France and under active consideration in Germany.
} 
exemptions $?^{41}$ How strong is the case for dual- or multiple-rate VATs? What should be the shape of the definitive regime for the coordination of the VATs between the Member States? Is cross-border shopping a problem of such magnitude that it requires agreement on a common maximum and minimum rate?

\section{(a) Survey of VATs}

Table 4 shows the VATs in the 15 Member States, arranged by type of rate structure: predominantly single-, dual- or multiple-rate VATs. All Member States bar Denmark impose one or more reduced rates on items regarded as essential, such as food products, medicines, books, newspapers and passenger transportation. The UK and Ireland even zero-rate these (and various other) items. The coverage of the reduced rates ranges from 20 percent (Germany) to 40 percent (UK) of total consumption expenditures. ${ }^{42}$ Standard rates range from 15 percent in Luxembourg to 25 percent in Denmark and Sweden.

The high rates in conjunction with the broad base have made the VAT an important revenue-generator in all Member States (comparable to the wage and social security withholding tax schemes). In 1999, the VATs contributed, on average, 18.1 percent of total tax revenue (inclusive of social security contributions) or 7.4 percent of GDP (Table 4). Since the VAT was introduced, the average standard rate has increased from 13.9 percent to 19.4 percent at present - by almost 40 percent. ${ }^{43}$ On average, the VAT ratios - i.e. VAT revenue as a percentage of GDP - are one-and-a-half times the ratios for the predecessor sales taxes. ${ }^{44}$ In the UK, the VAT ratio now is three times higher than the ratio for the erstwhile purchase tax. No doubt, the revenue-generating capacity of the VAT owes much to its inherent robustness ${ }^{45}$ and low excess burden. ${ }^{46}$ Although

\footnotetext{
${ }^{41}$ In addition, as the European Commission (1996a) has pointed out, various concepts, such as the place of supply rules, require review. However, legal issues, important in their own right, are not dealt with in this paper.

${ }^{42}$ These figures are based on Cnossen (1983, table 7.2). Although dated, the shares of the reduced rates in total consumption are likely to have changed relatively little in view of the largely harmonized coverage of the reduced rates under the Sixth Directive.

${ }^{43}$ Increases of 5 percentage points or more were recorded in Denmark, Germany, Italy, the Netherlands, Luxembourg and the UK.

${ }^{44}$ Thus, the average increase in revenue as a percentage of GDP is greater than the average increase in standard VAT rates. This is due to improved administration and the expanded coverage of the standard-rate category. In many Member States, important items, such as fuels, were moved from the lower- to the standard-rate category. ${ }^{45}$ The VAT is administratively and politically robust because it pays to be a taxable person (except where exemption occurs at the last stage). As Ben Terra once noted, fundamentally, those that are taxed are exempt and those that are exempt are taxed. By implication, political tinkering with the tax base in response to specialinterest groups is discouraged.

${ }^{46}$ The major distortion under a comprehensive uniform-rate VAT pertains to the labor-leisure choice.
} 
Sijbren Cnossen

TABLE 4

VATs in EU Member States, 2002

\begin{tabular}{|c|c|c|c|c|}
\hline & \multicolumn{2}{|c|}{ VAT rates $(\%)^{a}$} & \multicolumn{2}{|c|}{ VAT revenue as percent of: } \\
\hline & Standard & Other $^{\mathrm{b}}$ & $\begin{array}{l}\text { Total tax } \\
\text { revenue }\end{array}$ & GDP \\
\hline Single-rate VATs & & & & \\
\hline Denmark & 25 & $-^{\mathrm{c}}$ & 19.2 & 9.7 \\
\hline Dual-rate VATs & & & & \\
\hline Austria & 20 & $10^{\mathrm{d}}$ & 19.0 & 8.4 \\
\hline Germany & 16 & 7 & 18.4 & 6.9 \\
\hline Netherlands & 19 & 6 & 16.9 & 7.1 \\
\hline UK & 17.5 & $0^{\mathrm{e}}$ & 18.8 & 6.8 \\
\hline Multiple-rate VATs & & & & \\
\hline Belgium & 21 & $6 / 12^{\mathrm{f}}$ & 16.0 & 7.3 \\
\hline Finland & 22 & $8 / 17^{\mathrm{g}}$ & 18.8 & 8.7 \\
\hline France & 19.6 & $2.1 / 5.5$ & 17.3 & 8.0 \\
\hline Greece & 18 & $4 / 8$ & 21.7 & 8.0 \\
\hline Ireland & 20 & $0 / 12.5^{\mathrm{h}}$ & 22.0 & 7.1 \\
\hline Luxembourg & 15 & $3 / 6 / 12$ & 15.0 & 6.3 \\
\hline Italy & 20 & $4 / 10^{\mathrm{i}}$ & 13.7 & 5.9 \\
\hline Portugal & 17 & $5 / 12$ & 23.7 & 8.1 \\
\hline Spain & 16 & $4 / 7$ & 17.5 & 6.1 \\
\hline Sweden & 25 & $6 / 12^{j}$ & 13.8 & 7.2 \\
\hline Unweighted averages & 19.4 & & 18.1 & 7.4 \\
\hline
\end{tabular}

${ }^{a}$ Rates are in tax-exclusive form, i.e. specified as a proportion of the net-of-tax price.

${ }^{\mathrm{b}}$ Not including the zero rate on exports.

${ }^{\mathrm{N}}$ Newspapers are taxed at 0 percent.

${ }^{\mathrm{d}}$ Wine supplied by farmers and electrically driven vehicles are taxed at 12 percent

'Certain 'energy-saving materials' are taxed at 5 percent. An effective rate of 5 percent is also applied to some imported works of art, collector's items and antiques.

Newspapers, magazines and waste products are taxed at 0 percent

${ }^{g}$ Newspapers and magazines are taxed at 0 percent.

${ }^{\mathrm{h}}$ Livestock and greyhounds are taxed at 4.3 percent.

${ }^{\mathrm{i}}$ Waste paper and scrap iron are taxed at 0 percent.

${ }^{\mathrm{j}}$ Prescribed medicines are taxed at 0 percent.

Sources: Rates - International Bureau of Fiscal Documentation, Value Added Taxes in Europe, Amsterdam, loose-leaf; revenues (1999) - OECD (2001). Reduced rates apply to supplies in Jungholz and Mittelberg (Austria), the Aegean Islands (Greece), Corsica (France) and the Autonomous Regions (Portugal).

VAT's operational costs are not negligible, per euro of revenue they are substantially lower than those of a business income tax. ${ }^{47}$

${ }^{47}$ For the evidence, see Cnossen (1994), who estimates the administrative costs of a 'best-practice' VAT at US $\$ 100$ per taxable business per annum. Administrative costs vary widely between Member States, depending on the complexity of the VAT as reflected in factors such as the number of rates, the size of the threshold, 


\section{(b) VAT Exemptions}

Efficiency in production and tax collection is best served if the VAT is imposed on the widest possible range of goods and services that are used or consumed by businesses and individuals. Exemptions violate the logic and functionality of the VAT. They distort input choices and harm exports. It is widely agreed that exemptions should be limited to those dictated by strict administrative costbenefit considerations. If externalities are prevalent, zero-rating rather than exemption is the appropriate recipe. The Sixth Directive fails to meet this standard.

\section{Standard Exemptions}

The standard exemptions under the Sixth Directive include healthcare, education, social services, cultural services, public radio and television broadcasts, postal services, immovable property, insurance, financial transactions and gambling. Most of these exemptions are in conflict with 'best practice'.

\section{Cultural Services}

The case against the exemption of cultural services is particularly strong. Admissions to theatres, concerts, museums and the like compete with taxable forms of entertainment, such as travel and reading, and should therefore be taxed. Similarly, public radio and television broadcasts compete with taxable privately financed broadcasts and other forms of communication. This applies also to postal services (which compete with taxable private letter or parcel carriers), newspapers and periodicals. Since it is difficult to justify these exemptions on externality grounds, withdrawal seems indicated. Various Member States are coming around to this view. For instance, cultural services are now being taxed in Finland, Greece, the Netherlands, Spain and Sweden; radio and television broadcasting in Denmark; and postal services in Finland and Sweden.

\section{Health and Education}

Even the exemptions for healthcare and education services hardly stand up to close scrutiny. Admittedly, the externality arguments are much stronger than in

various special schemes and (lack of) compliance control jointly with the business income tax. Of the Member States surveyed, administrative costs were lowest in Sweden (US\$68) and highest in the UK (US\$200). Furthermore, Cnossen estimates compliance costs at US\$500 per taxable business per annum, again with wide differences between Member States. Compliance costs per US $\$ 1,000$ turnover in the UK, for instance, were six times the compliance costs in Germany. In spite of the relatively high threshold in the UK (and Ireland), small traders register anyway to obtain refunds of the tax on purchases (and other inputs) of zero-rated foodstuffs and various other items. 


\section{Sijbren Cnossen}

the case of cultural services, but if health and education services should be provided below cost, then (an increase in) budget subsidies (or a zero rate) would be the appropriate policy response. The exemptions violate production efficiency because the institutions providing healthcare and education services are induced to perform laundry, cleaning, food preparation and various other services in-house in order to save the payment of VAT on the labor element of these services, which would be payable had they been acquired from outside, taxable establishments. This hampers the contracting-out of these services (privatization) and thus the efficient functioning of the institutions. Exemption also raises the research cost for companies wishing to conduct research through hospitals and universities, because they cannot take implicit credit for the tax on the inputs used by the exempt institutions. These considerations become more important as the private provision of healthcare and education grows relative to public provision, as is happening in the EU. Taxing health (and cultural) services would most likely shift the tax burden to the richer elderly.

\section{Immovable Property}

It is difficult, politically and administratively, to tax residential rents and rental values of owner-occupied property. ${ }^{48}$ Instead, new buildings are taxed and subsequent sales exempted. This seems an acceptable second-best solution, because, in theory, the tax on a new building equals the present value of the tax on all future services, reflected in residential rents and rental values, of the building. However, under the Sixth Directive, the exemption also extends to commercial property, which means that increases in the value of the property, and hence in the services provided by the property, are not included in the tax base. This violates production efficiency. The Member States should be advised, therefore, to tax all supplies of immovable property except residential housing, rather than to exempt all supplies except new buildings.

\section{Financial Services}

Administratively beyond reach so far are financial transactions, because the intermediation charge, which should be taxed, cannot be separated from the pure interest rate, premium or rate of return, which should not be taxed. ${ }^{49}$ The exemption also compromises the destination principle, because some VAT enters into the export cost of financial services and thus becomes a tax on factor

\footnotetext{
${ }^{48}$ Austria is the only Member State that taxes the letting of private housing, which therefore does not have to be delineated from hotels and boarding houses. For a review of the theory and practice of the VAT treatment of immovable property, see Cnossen (1996).

${ }^{49}$ The same issue arises under insurance contracts with a saving feature. If contracts do not have a saving feature, insurance can be taxed like any other product. New Zealand, for instance, taxes fire and casualty insurance by levying VAT on the premiums and permitting a tax credit on indemnity payments.
} 
incomes. ${ }^{50}$ Furthermore, various administrative complications arise. Taxable 'secondary services' (accounting and tax advice, for instance) must be delineated from exempt 'core services' and the input tax apportioned accordingly. Optional registration in France and Germany does not seem to offer a viable solution. Nor do zero-rating and addition and subtraction methods. ${ }^{51}$

Perhaps the cash-flow approach, pioneered by Poddar and English (1997), deserves further scrutiny. Under the cash-flow approach, cash inflows from financial transactions (deposits, interest receipts) are treated as taxable sales, and cash outflows (loans, interest payments) are treated as purchases of taxable inputs. The VAT on these inputs, along with the VAT on inputs of nonfinancial goods and services, would be creditable against the VAT on outputs. The VAT on outputs, in turn, would constitute input tax credits for other taxable persons. (At the same time, of course, these taxable persons would pay VAT on their inflows, e.g. loans extended by banks.) As a result, tax cascading, inherent to the exemption approach, would be avoided, while consumers would be taxed in full. The cash-flow method can be made compatible with the destination principle, simply by ignoring the provision of financial services to or from nonresidents.

The EU (European Commission, undated) has closely considered Poddar and English's ingenious idea, but doubts remain about its practicability. 'Trying to get to grips with banking ... is akin to trying to get your hands around a piece of jelly,' as Tait (1991) puts it succinctly. ${ }^{52}$

\section{Treatment of Specified Activities}

In addition to the standard exemptions, the Sixth Directive exempts specified activities of public sector bodies, small businesses and farmers.

\section{Public Bodies}

Early on, it was considered odd if government would pay VAT to itself on the services it provided. So, activities performed by public authorities were exempted unless treatment as a nontaxable person 'would lead to significant distortions of competition.' But nowadays, it is widely agreed that there are few government services that cannot be provided by the private sector. ${ }^{53}$ The distortion of input prices violates the conditions for cost minimization - the

\footnotetext{
${ }^{50}$ More generally, Feldstein and Krugman (1990) have argued that exemptions from VAT usually fall on nontradable rather than tradable goods and services. Hence, VAT exemptions discourage trade and raise the production and consumption of nontradables.

${ }^{51}$ For a review of the exemption approach, optional registration, zero-rating and addition and subtraction methods, see Cnossen (1999a).

${ }^{52}$ As pointed out by Bradford (1996), the problems that bedevil the VAT treatment of financial services are very similar to the problems with the treatment of financial services under the income tax.

${ }^{53}$ The exemption of public bodies, moreover, has little meaning if legal restrictions, pricing-cum-subsidy schemes or the status of public monopoly in effect preclude competition by the private sector.
} 
counterpart of profit maximization in the private sector. This is particularly true for local and provincial or state governments. ${ }^{54}$ Recently, Aujean, Jenkins and Poddar (1999) have made a cogent case for the wider taxation of public bodies. As with hospitals, universities and financial institutions, this would obviate the need for delineation between taxable and exempt government activities as well as for special charging provisions if taxable goods and services are acquired outof-state.

\section{Small Businesses}

Since compliance costs are largely fixed costs independent of the VAT payable, they fall especially heavily on small traders. The compliance costs of small traders (with turnover below 60,000 euro) are of the order of 2 percent of turnover, but costs are merely 0.3 percent for larger firms (with turnover above 1 million euro) ${ }^{56}$ In competitive markets, the higher compliance costs of small traders generally cannot be passed on to consumers. In other words, they tend to reduce the disposable income of the small traders themselves. ${ }^{57}$ Prima facie, compliance costs can be reduced by increasing the small-business exemption, which is now 5,000 euro of annual turnover. The issue features as a 'potential future priority' in the Commission's VAT action program.

The VAT is also onerous for small businesses on account of various exceedingly complex schemes to make small firms pay some tax. These schemes range from the equalization tax on supplies to exempt small retailers in Spain; the vanishing tax reduction for small businesses related either to net tax payable or to turnover found in Finland, France, Luxembourg and the Netherlands; the presumptive tax schemes (based on business surveys) applied by tax offices in Belgium, France, Italy and Spain; to the application of flat tax rates to the turnover of small firms in lieu of an exact computation of the tax liability in Germany and Italy. These schemes add greatly to administrative and compliance costs without contributing much to revenue. Experience in new-VAT countries indicates that the simplest small-firm scheme is a fairly generous exemption without any strings attached. Austria adopted this approach in 1989 by abolishing all simplified schemes for small businesses.

\footnotetext{
${ }^{54}$ To avoid this effect, Luxembourg, France, the Netherlands and the UK refund the tax on inputs of local governments, in effect zero-rating their activities. This eliminates both the distortion of input choices and the bias against contracting-out.

${ }^{55}$ Essentially the same issues arise regarding exempt nonprofit bodies.

${ }^{56}$ See especially Sandford, Godwin and Hardwick (1989).

${ }^{57}$ Assuming a profit margin of 35 percent, the higher compliance costs of 1.7 percentage points of turnover are equivalent to a 5 percent flat, regressive income tax.
} 


\section{Agriculture}

Finally, the Sixth Directive permits the taxation of farmers on the basis of flatrate schemes that compensate them for the tax borne on agricultural inputs. This tax is estimated as a presumptive percentage of farm output. Farmers can then add the tax to their bills of sale (and be taxed at the same rate) or purchasers of farm produce can directly take a credit for the presumptive tax. In either case, farmers do not have to register for or pay the VAT. Obviously, the schemes provide only rough justice and, just like the old turnover tax, can be used to subsidize farmers. Best practice would be to make farmers fully liable for VAT, subject to the small-business exemption. This is already being done in Denmark, Sweden and the UK.

\section{Conclusion}

Invariably, the exemptions and special schemes violate production and tax collection efficiency, as well as complicating compliance and administration. ${ }^{58}$ Newcomers to the VAT, such as Australia, Canada and New Zealand, have followed best practice by taxing or zero-rating nearly all of the exempt services listed above. ${ }^{59}$ Generally, primary and secondary education and financial transactions are the only exceptions. Zero-rating may be the best choice, since it avoids an artificial but politically sore point of an increase in the VAT ratio (compensated by an increase in subsidies). Similarly, there is a strong case for reviewing the treatment of government activities, farmers and small businesses. In short, a comprehensive overhaul of the Sixth Directive seems called for. But under the Treaty of Rome this requires unanimity, which is hard to come by. If the EU Member States are not to be locked into outmoded VATs, perhaps they should be permitted to have better VATs than provided by the Sixth Directive. ${ }^{60}$ As a result, intra-EU trade probably would be less distorted than is the case under current VATs.

\section{(c) Single- or Differentiated-Rate VATs?}

The rationale for most exemptions must be found in the history of the adoption of the various VATs, not in their underlying economic or administrative logic. This is also true of the dual- and multiple-rate structures shown in Table 4. So-

\footnotetext{
${ }^{58}$ The existence of exempt sectors is sometimes used as an argument in favor of rate harmonization, because it would reduce distortions between tradable-goods sectors that use the goods of tax-exempt producers as inputs, as well as between exempt sectors that produce tradable goods (Bovenberg and Horne, 1992). Clearly, however, taxation would seem to be the preferred approach to eliminate distortions.

${ }^{59} \mathrm{New}$ Zealand taxes healthcare and education in full, Australia zero-rates these services, while Canada does not tax the services and provides a rebate of 50 percent of the tax on inputs to the MUSH sector (municipalities, universities, schools and hospitals).

${ }^{60}$ This need not affect the determination of the VAT contribution to the EU's 'own resources'.
} 


\section{Sijbren Cnossen}

called essential goods were taxed at reduced rates under predecessor sales taxes, so it seemed logical to continue the same treatment under the VAT.

In the mean time, it has become clear that reduced rates hardly mitigate the regressive burden distribution of the VAT measured against income. As early as 1988, the OECD concluded that it made little difference to the tax burden distribution whether food products were zero-rated (the UK), taxed at a reduced rate (the Netherlands) or even taxed at the same rate as other goods and services (Denmark). ${ }^{61}$ Tax-relevant differences in consumption patterns have largely disappeared in highly industrialized countries. Higher-income groups often buy varieties of particular commodities that are more expensive than the varieties bought by lower-income groups, but rate structures based on prices rather than commodities are not feasible. ${ }^{62}$ The rich also spend proportionately more than the poor on holidays abroad and on education, but these expenditures either cannot be taxed or are excluded on social grounds.

In short, differentiated VAT rates are an ineffective, ill-targeted instrument for eliminating the impact of the tax on the poor. Member States have available tax and income-support measures that are much better than a VAT for bringing the overall tax impact distribution in line with society's notions of ability to pay and income redistribution. Hemming and Kay (1981), for instance, find that there would be little change in the UK tax system's overall progressivity if zerorating were abolished and the increase in revenue were used to cut one point from the basic rate of income tax and to increase the tax threshold. An income tax is more sensitive than a VAT to the economic position and the personal circumstance of individual taxpayers. So is the social benefit system for people who do not pay income tax.

Furthermore, differentiated VAT rate structures are an administrative pain in the neck. They complicate the taxpayer's accounting system, require additional audit oversight, increase refunds, give rise to various definitional problems ${ }^{63}$ and

\footnotetext{
${ }^{61}$ Elsewhere, a New Zealand study (Australian Society of CPAs, 1998) indicates that merely 15 percent of the benefit of a zero rate on food would go to households with the lowest 20 percent of income. Similarly, computations by the US Congressional Budget Office (1992) show that a zero rate on food would reduce the regressivity of a hypothetical VAT by only 18 percent. For a recent review, see Cnossen (1999).

${ }^{62}$ As noted by the Irish Commission on Taxation (1984, appendix 9), the perverse effect of the Irish zero rate on food is that, in absolute terms, it gives twice as much relief to high-income groups as to low-income groups. Not only do the rich tend to buy more expensive varieties of food, but also they eat out more often and may be more inclined to throw food away. In the same vein, a Swedish study (Skall Matmomsen Slopas? 1983) concludes that the application of a zero rate on groceries would mainly benefit cohabiting yuppies - single people with higher incomes.

${ }^{63}$ Perhaps most telling in this connection is the admonition found in the loose-leaf edition of the International Bureau of Fiscal Documentation's Value Added Taxes in Europe regarding France's VAT rate structure: The application of the reduced rate of $5.5 \%$ is very complex. It applies to a great number of goods and services whose technical description generally falls outside the scope of this book. The application of the reduced rate is sometimes also dependent on the circumstances in which the transaction was effected. The tax authorities have issued a number of rulings in order to solve particular difficult
} 
invite misclassification. In the UK, firms with multiple-rate output have double the compliance costs of firms taxed at a single rate (Hemming and Kay, 1981). ${ }^{64}$ Agha and Haughton (1996) find that by adding another VAT rate, the compliance rate is reduced by 7 percentage points. Differential rates may also erode the tax base. Typically national preferences inexplicably appear to be especially deserving. ${ }^{65}$

In short, differentiated rate structures do not pass the litmus test. ${ }^{66}$ In all EU Member States, the income taxes and social benefit systems are much-bettertargeted instruments to mitigate the regressive impact of the VAT. Yet, dual rates are probably here to stay, because concessionary treatment, once extended, is politically difficult to withdraw. ${ }^{67}$ What could be done in any case is to streamline the coverage of the reduced rates. Luxembourg, the Netherlands and Spain, for instance, expanded the coverage of the reduced rate to all food for human and animal consumption whether consumed on or off the premises. In doing so, they abolished all differentiation within the category foodstuffs between essential and nonessential items (which makes even less sense than the differentiation between all foodstuffs and other products). By contrast, Austria and Germany, while taxing most food products at the reduced rate, apply the standard rate to seafood.

questions. The following discussion, therefore, gives only an indication of the cases in which the reduced rate applies.

${ }^{64}$ Perhaps the UK's VAT is not far behind in matching the complexity of France's VAT. For instance, the following factors have to be considered in applying the zero rate to food: place of consumption, timing of consumption, temperature, saltiness, number, volume, concentration, sugar content, use of fingers in consumption and alcoholic content.

${ }^{65}$ In Belgium, for instance, soap is taxed at the lower rate of 6 percent (one smells the difference); in Ireland, a zero rate is imposed on candles (devotion deserves to be stimulated); in the Netherlands, flowers used to be taxed at the lower rate (who would dare to question this in tulip country, except the Dutch?); and in France, monuments and memorials receive favorable treatment (Gallic glory must be preserved in stone).

${ }^{66}$ Reduced rates as well as uniform VAT rates are at odds, of course, with the Ramsey inverse-elasticity rule of taxation, which holds that the efficiency costs of taxation can be minimized by applying higher-than-average rates to goods with price-inelastic demand and lower-than-average rates to goods with price-elastic demand. As Harberger (1990) has argued persuasively, however, uniform taxation can be defended on pragmatic policy grounds. Unlike the Ramsey-rule solution, it does not require knowledge of demand and supply relations (generally not available anyway) and is more robust to changes in tastes and technology. (To be sure, differences in intra-EU VAT rates reduce efficiency in exchange because they drive a wedge between the marginal rates of substitution faced by consumers residing in different Member States.) Furthermore, nonuniform rates can be used for protective purposes by imposing higher rates on goods and services that are mainly imported and lower rates on goods and services that are mainly exported and on nontradable goods and services.

${ }^{67}$ A notable exception is Portugal, which abolished the zero rate for foodstuffs. Hungary, one of the new accession countries, did the same. 
Sijbren Cnossen

\section{(d) Interstate Coordination}

\section{Current Arrangements and Perceived Problems}

Upon the abolition, in 1992, of border controls between its Member States, the EU agreed to tax cross-border trade between registered businesses within the EU on a deferred payment or postponed accounting basis. ${ }^{68}$ Although, per force, over-the-counter sales to nonregistered traders and consumers are taxed on an origin basis, the VAT on transactions between registered businesses is collected on a reverse charge basis: purchasers of out-of-state goods and services declare the imports, called acquisitions, apply VAT and take credit for the same amount, all in the same return. ${ }^{69}$ The deferred payment system is backed up by a VAT Information Exchange System (VIES for short), which requires taxable persons to file quarterly reports of out-of-state supplies and acquisitions. In addition, a statistical data collection system, referred to as the Intrastat system, was set up to collect trade data on goods (not services) between Member States.

The deferred payment system breaks the fractional VAT collection process, however, because intra-Community supplies are zero-rated. This enlarges the scope for 'carousel' (export of goods at zero VAT and return for sale VAT-free) and similar frauds. According to the European Commission, an examination of a thousand reported VAT frauds revealed 1300 million euro of VAT forgone, which it believed to be 'the tip of the iceberg' (quoted in European Parliament, 2001). For this reason, it seeks to replace the 'transitional regime' by a 'definitive regime' under which exports by registered traders would be subject to the VAT of the Member State of sale.

\section{Alternatives to the Transitional Regime}

The Commission has developed two alternatives to the transitional regime for the trade between registered traders. Not to be outdone, the tax literature has added two more. The requirements for the alternatives are in order of importance: (i) operational autonomy of the Member States, particularly with regard to rate setting; (ii) no distinction to be made between domestic and out-ofstate sales (i.e. no break in the VAT chain); and (iii) compliance cost and enforcement symmetry between importing and exporting Member States.

\footnotetext{
${ }^{68}$ The deferred payment system has been in use in the Benelux countries ever since these countries introduced the VAT in the late 1960s and early 1970s and has been incorporated in Title XVIA of the Sixth Directive (Cnossen, 1998). The system is backed up by special rules for cross-border mail-order sales (subject to the VAT of the country of destination), cross-border purchases by exempt entities (obliged to file returns and pay VAT) and cross-border car purchases (subject to VAT in the country of registration).

${ }^{69}$ The reverse charge procedure has led to various problems with the expansion of internet and the arrival of ecommerce (European Commission, 1998). Electronic goods downloaded from outside the EU are not subject to VAT. A number of proposals have been made to deal with third-country suppliers: registration in a single Member State (Commission), all Member States (France), and no tax at all on e-commerce (UK). Discussions on the problem continue in Council.
} 
The four destination-based alternatives are the following:

- The clearing house (Cnossen, 1983; European Commission, 1985), under which out-of-state exports would be taxed by the Member State of origin and importers would be entitled to a tax credit for the out-of-state VAT. To restore the workings of the destination principle, the VAT administration of the exporting state would remit the VAT collected on exports to the administration of the importing state. Basically, only net balances would have to be settled, possibly through some central clearing house. Since, subsequently, clearing on the basis of individual transactions was considered too cumbersome, the Commission proposed clearing on the basis of estimates of consumption in the various Member States. As pointed out by Lee, Pearson and Smith (1988), enforcement asymmetry is the most serious flaw of the clearing house. Importing Member States have little incentive to verify the claim for tax credits on out-of-state purchases. But this would seem to apply to all tax-information-sharing agreements.

- Home-state taxation (European Commission, 1996a), i.e. VAT collection by the place of business establishment, instead of, as at present, the location of the transaction. This would involve abolition of zero-rating of intra-EU transactions, cross-border sales being taxed in the same fashion as domestic sales and cross-border movement of goods within the same business going untaxed. As under the clearing house, importers would be able to credit the VAT on out-of-state purchases against their own VAT liability. VAT revenues on interstate transactions would be allocated between Member States on the basis of statistics of aggregate consumption. The drawbacks of this proposal are considerable involvement of the central level, enforcement asymmetry and perverse effects on the choice of the location of business establishment (Smith, 1997).

- The compensating VAT (CVAT) on sales between Member States (McLure, 2000; Versano, 2000), which would leave zero-rating of sales between Member States intact, but would impose a central VAT solely for the purpose of protecting the VAT chain in addition to the VATs of the Member States. ${ }^{70}$ No net revenue would be collected under the CVAT, because the VAT on exports would be canceled by the tax credit of the VAT on imports. Obviously, the CVAT requires a central administration, including uniform laws. Traders, moreover, would still have to make a distinction between domestic sales subject to the national VAT and out-of-state sales which would be zero-rated under the national VAT but taxed under the CVAT. ${ }^{71}$

\footnotetext{
${ }^{70}$ McLure (2000) notes that '[t]he CVAT minimizes the risk that households and unregistered traders will attempt to masquerade as registered traders located in other states, in order to make zero-rated purchases'.

${ }^{71}$ The enforcement properties of the CVAT resemble the workings of the dual VAT in Canada, i.e. the combination of a federal VAT with a provincial VAT in Quebec (and piggybacked VATs in the Atlantic
} 
- The viable integrated VAT (VIVAT) developed by Keen and Smith (1996, 1999), which would preserve the VAT chain by imposing an EU-wide uniform rate on all cross-border transactions between registered traders. Exports would be taxed and importers would be entitled to a tax credit for out-of-state purchases. A Member State's preference for a VAT rate higher than the common rate would be satisfied by permitting it to differentiate its rate for sales not made to registered traders (e.g., at retail). The problem with this scheme is that it substitutes the requirement that a distinction be made between domestic and out-of-state transactions by a perhaps more onerous distinction between retail sales and out-of-state sales.

\section{Improving the Transitional Regime}

A number of points can be made in comparing these alternatives with the current transitional regime.

First, none of the proposals listed above produces any evidence that the zerorating of out-of-state supplies under the transitional regime involves unmanageable fraud. Interestingly, the Member States do not complain about the regime. The Benelux countries have operated the transitional regime (without even requiring identification numbers until 1992) ever since they introduced the VAT. Exemption of sales between related firms, as proposed under home-state taxation and probably also desirable under the clearing house, would similarly move out-of-state supplies outside VAT control.

Secondly, the weight that is attached to the no-break-in-the-VAT-chain criterion seems somewhat exaggerated (the same applies to the criterion of enforcement symmetry). The zero-rating of exports moves the VAT somewhat closer to a retail sales tax, which suspends the tax liability throughout the entire pre-retail production and distribution chain. But that is all. The EU once formulated the requirement that exports should be taxed and the tax on imports not be remitted, in the belief that the destination principle should be replaced by the origin principle. ${ }^{73}$ Later developments showed that the belief was misplaced.

Thirdly, the alternatives focus nearly exclusively on the movement of goods. Reverse charge mechanisms would have to remain in place for the out-of-state provision of services, both from within and from outside the EU. Indeed, it is hard to envisage any watertight no-break-in-the-VAT-chain system of control (that would not have to rely on voluntary compliance), if desired, without some form of international cooperation in addition to EU-wide controls.

Fourthly, and perhaps most importantly, the transitional regime in conjunction with the VIES is equivalent in effect to the CVAT. Under both

provinces). Bird and Gendron $(1998,2000)$ advocate this dual VAT for use in federal countries. For a recent review of various VAT cooperation schemes, see also Bird and Gendron (2001).

${ }^{72}$ Keen and Smith (1996) note that ' $[\mathrm{t}]$ his is not a trivial burden'.

${ }^{73}$ See the preamble to the Second Directive on Value Added Tax. 
systems, out-of-state supplies are monitored: by a central administration under CVAT (with zero revenue) and on a bilateral but centrally prescribed basis under VIES. But a central CVAT would probably be more costly to administer than a well-designed VIES, because it would require a central administration. ${ }^{74}$

In light of these considerations, the transitional regime would seem to deserve a second hearing. ${ }^{75}$ To be sure, the regime requires review, because the compliance costs for VAT and especially Intrastat with respect to out-of-state supplies are exceptionally onerous. Verwaal and Cnossen (2002) have shown that, for Dutch firms, the differential compliance costs of VIES and Intrastat are, on average, 5 percent of the value of intra-EU transactions (and they exceed 12 percent of value if firms have only 12 transactions or fewer per annum). ${ }^{76}$ The trade data required under Intrastat are particularly onerous, accounting for over 80 percent of differential compliance costs. Both the additional VAT requirements and the Intrastat obligations act as border taxes that impede intraEU trade and distort competition.

Verwaal and Cnossen (2002) suggest that the fragmentary Intrastat obligations should be abolished. ${ }^{77}$ The introduction of the euro obviates the need to collect data for trade and exchange rate policy purposes. Beyond that, the obligations do not apply to services, a large and growing proportion of intra-EU trade. Moreover, declared values of intercompany transactions, representing a sizable portion of intra-EU trade in goods, are largely meaningless. To improve compliance control on out-of-state transactions, the authors suggest that individual Member States should be encouraged to perform joint audits of VAT returns (by analogy, bilateral and multilateral agreements already exist to investigate criminal activities). Also, firms with a small volume of intra-EU trade could be compensated for the disproportionately higher differential compliance costs that they incur. Compensation equal to 5 percent of the first 1 million euro of out-of-state sales would reduce average compliance costs to less than 0.5

\footnotetext{
${ }^{74}$ McLure (2001) emphasizes that the CVAT was designed primarily for developing countries and countries in transition, where breaks of credit on internal trade probably would be important. In his view, the CVAT is not needed in the EU, where there is high-quality tax administration and an adequate level of communication and cooperation between tax authorities.

${ }^{75}$ In its Communication of June 2000, the European Commission (2000) gave priority to improving the transitional regime rather than to creating a definitive regime based on the Member State of sale.

${ }^{76}$ As the authors indicate, it is unlikely that the differential compliance costs would be lower in other Member States. The Netherlands has a VAT administration that is exceptionally exporter-friendly on account of the many EU-wide distribution networks in the country. In addition, it has ample experience with the transitional regime.

${ }^{77}$ Intrastat requires data for each category of goods (identified by the corresponding eight-digit code) on the Member State of supply and acquisition, volume, value, nature of the transaction, supply conditions and the probable mode of transportation.
} 
percent of the value of these sales. ${ }^{78}$ As a complementary measure, large firms that form links in complex intra-EU supply chains might be issued licenses permitting them to trade with firms in other Member States on a no-tax basis.

\section{Is Rate Approximation Really Necessary?}

Minimum standard and reduced rates were agreed upon (with the notable exception of the zero rate in Ireland and the UK) at the end of 1992, purportedly to reduce the incentive for cross-border shopping. However, the evidence that was available at that time did not indicate that the agreement was necessary. Table 5 shows that the magnitude of cross-border shopping is minimal. The studies mentioned in the table conclude that the magnitude of cross-border shopping diminishes rapidly with the distance that must be covered to shop more cheaply elsewhere. ${ }^{79}$ Although the magnitude is not irrelevant in the border regions themselves, it is small in the national context. In South-Limburg, twothirds of retail sales lost on account of cross-border shopping was made up by purchases of nonresidents living across the border in Belgium and Germany (this effect is not shown in the table). Furthermore, on a net basis, two-thirds of the value of cross-border shopping had to be attributed to consumer purchases subject to excises. In other words, differences in excises rather than VAT rates are at the root of the cross-border shopping issue.

TABLE 5

Cross-Border Shopping in Some EU Regions

\begin{tabular}{ll|c|lr|cc}
\hline $\begin{array}{l}\text { Member } \\
\text { State }\end{array}$ & \multicolumn{1}{c|}{ Region } & Year & \multicolumn{2}{|c|}{$\begin{array}{c}\text { Difference in } \\
\text { standard rate } \\
\text { (\% points) }\end{array}$} & \multicolumn{2}{|c}{$\begin{array}{c}\text { Percentage of } \\
\text { consumption expenditures } \\
\text { Regional }\end{array}$} \\
\hline Netherlands & South-Limburg & 1991 & Germany & 4.5 & 8.5 & 0.6 \\
Denmark & Sønderjylland & 1991 & Belgium & -0.5 & & \\
Denmark & $<50 \mathrm{~km}$ & 1985 & Germany & 8.0 & 5.7 & 0.9 \\
Ireland & Border counties & 1986 & UK & 10.0 & 10.0 & 1.0 \\
\hline
\end{tabular}

Sources: Netherlands and Denmark - Bode, Krieger-Boden and Lammers (1994); Denmark - Bygrå et al. (1987); Ireland - Fitz Gerald et al. (1988).

Furthermore, Fitz Gerald, Johnston and Williams (1995) did empirical research (based on interviews with 2,000 households) on the distance that Irish buyers are prepared to travel to be able to shop more cheaply in the UK. It

\footnotetext{
${ }^{78}$ Compensation might take the form of a proportional tax credit against the VAT payable as shown on the return. Interestingly, Denmark has a mechanism under its income tax to compensate small firms for the disproportionately higher compliance costs that they incur (Sandford, 1995).

${ }^{79}$ In addition, it is not possible to avoid the VAT on mail-order purchases and certain consumer durables, such as motor vehicles and yachts, because tax must be paid in the Member State of destination or registration.
} 
transpired that Irish consumers appear to be willing to travel more than 50 kilometers only if the VAT-induced price difference is 10 percent or more at an expenditure level of 300 euro or higher. The Irish do not shop across the border for purchases of 100 euro or less. The study therefore concludes that substantial VAT differences are tolerable in a internal market without harming the VAT yield of individual Member States. Again, the study shows that excise differences (high taxes on relatively expensive but small-volume articles) dominate cross-border-shopping behavior.

These findings are corroborated by various Commission reports which have found that the abolition of border controls has resulted in "no significant changes in cross-border purchasing patterns, nor any significant distortions of competition or deflections of trade through disparities in VAT rates' (European Parliament, 2001). They indicate that EU-wide agreements on minimum (or maximum) VAT rates are not necessary and therefore not desirable.

\section{Excises}

Although Article 99 (old) of the Treaty of Rome mentions excises in the same breath as sales taxes as prime candidates for harmonization, so far progress has been excruciatingly slow. Often, excise harmonization has been spontaneous, i.e. as borders came down and mobility increased, excises were reduced to their lowest common rate.

The coordination of the excises in the EU is based on three sets of directives: (i) three directives on the structures of the excises on manufactured tobacco (cigarettes and manufactured tobacco other than cigarettes; Directive 95/59/EC), alcohol and alcoholic beverages (Directive 92/83/EEC) and mineral oils (Directive 92/81/EEC); (ii) four directives on the approximation of the rates of duty applicable to these products (Directives 92/79/EEC, 92/80/EEC, 92/84/EEC and 92/82/EEC); and (iii) a directive on the duty-free movement and monitoring of excisable products (in lieu of previous border controls) between Member States (Directive 92/12/EEC).

\section{(a) Review and Developments}

Table 6 shows excise revenue as percentages of GDP and of total tax revenue, as well as current excise duties on tobacco, alcohol and gasoline in the various Member States. In 1999, total excise revenues averaged 3.8 percent of GDP for the EU as a whole, down from 4.4 percent in 1970. Since the total tax ratio, according to OECD (2001), rose from 31.2 percent to 41.3 percent in the period under review, excise revenue as a percentage of total tax revenue declined by, on average, an eighth. ${ }^{80}$ As indicated by the table, wide differences exist between

\footnotetext{
${ }^{80}$ In evaluating the revenue role of excisable products, the VAT, which is imposed at standard rates on exciseduty-inclusive prices, should also be taken into consideration. Generally, the sales taxes levied prior to the
} 
Sijbren Cnossen

Member States. Denmark collects 5.6 percent of GDP in excise revenue, but Belgium is content with 2.4 percent. Ninety percent of excise revenues derive from three products - tobacco, alcohol and mineral oil.

TABLE 6

Excises in the EU, 2002

\begin{tabular}{|c|c|c|c|c|c|c|c|}
\hline \multirow[t]{2}{*}{$\begin{array}{l}\text { Member } \\
\text { State }^{a}\end{array}$} & \multicolumn{2}{|c|}{$\begin{array}{l}\text { Excise revenue } \\
\text { as percent of: }\end{array}$} & \multirow[t]{2}{*}{$\begin{array}{l}\text { Pack of } 20 \\
\text { cigarettes }^{b}\end{array}$} & \multirow[t]{2}{*}{$\begin{array}{l}1 \text { liter of } \\
\text { beer }^{c}\end{array}$} & \multirow[t]{2}{*}{$\begin{array}{l}1 \text { liter of } \\
\text { wine }^{d}\end{array}$} & \multirow{2}{*}{$\begin{array}{c}0.75 \text { liter } \\
\text { of } 40 \% \\
\text { spirits }^{e}\end{array}$} & \multirow{2}{*}{$\begin{array}{l}1 \text { liter of } \\
\text { unleaded } \\
\text { gasoline }\end{array}$} \\
\hline & $\begin{array}{l}\text { GDP } \\
(\%)\end{array}$ & $\begin{array}{c}\text { Total tax } \\
\text { revenue } \\
(\%)\end{array}$ & & & & & \\
\hline Denmark & 5.6 & 11.0 & 3.29 & 0.62 & 0.95 & 11.09 & 0.54 \\
\hline Luxembourg & 5.0 & 12.0 & 1.41 & 0.01 & 0 & 3.12 & 0.37 \\
\hline Finland & 4.7 & 10.1 & 3.03 & $0.29 *$ & 2.35 & 15.14 & 0.56 \\
\hline Portugal & 4.6 & 13.5 & 1.51 & 0.17 & 0 & 2.51 & 0.48 \\
\hline Ireland & 4.5 & 13.8 & 3.97 & $0.19^{*}$ & 2.73 & 8.29 & 0.51 \\
\hline Greece & 4.4 & 11.9 & 1.70 & 0.01 & 0 & 2.72 & 0.32 \\
\hline UK & 3.6 & 10.0 & 5.64 & $0.19 *$ & 2.50 & 9.50 & 0.79 \\
\hline Sweden & 3.5 & 6.8 & 2.70 & $0.15^{*}$ & 2.26 & 15.45 & 0.48 \\
\hline Netherlands & 3.5 & 8.3 & 2.07 & 0.25 & 0.59 & 4.51 & 0.61 \\
\hline Italy & 3.5 & 8.0 & 1.54 & 0.01 & 0 & 1.94 & 0.52 \\
\hline France & 2.9 & 6.4 & 2.71 & $0.03 *$ & 0.03 & 4.35 & 0.57 \\
\hline Spain & 2.8 & 7.9 & 1.33 & 0.01 & 0 & 2.22 & 0.43 \\
\hline Germany & 2.8 & 7.3 & 2.29 & 0.01 & 0 & 3.91 & 0.62 \\
\hline Austria & 2.7 & 6.2 & 1.96 & 0.02 & 0 & 3.00 & 0.41 \\
\hline Belgium & 2.4 & 5.2 & 2.09 & 0.02 & 0.47 & 4.98 & 0.49 \\
\hline Average & 3.8 & 9.2 & 2.48 & 0.13 & 0.79 & 6.18 & 0.51 \\
\hline
\end{tabular}

${ }^{\mathrm{a}}$ In descending order of excise revenue to GDP ratio.

${ }^{\mathrm{b}}$ Excises and VAT on the most popular price category of cigarettes.

${ }^{\mathrm{c}}$ The agreed minimum excise duty is 748 euro per hectoliter per degree Plato of finished product or, in the case of those countries marked $*, 1.87$ euro per hectoliter per degree of alcohol of finished product.

${ }^{\mathrm{d}}$ On still wine, the agreed minimum excise duty is 0 euro per hectoliter of product.

The agreed minimum excise duty is 550 euro or 1,000 euro per hectoliter of pure alcohol.

${ }^{\mathrm{f}}$ The agreed minimum excise duty is 287 euro per 1,000 liters.

Sources: Revenues (1999) - OECD (2001), headings 5221 (excises) and 5122 (profits of fiscal monopolies); duties - Mogensen (2002).

The harmonization of the excises seems more urgent than the harmonization of the VAT for four reasons. First, excises, particularly on drinking and smoking, probably interfere less with production efficiency than the VAT, let alone taxes

introduction of the VAT did not include excisable products in the base. Since VAT does apply to these products, the excise-plus-VAT ratios probably did not decline. 
on labor and capital. Secondly, harmonization would reduce the incentive for tax-base snatching, i.e. setting low excise duty rates to attract consumers from other Member States. As argued above, cross-border shopping is mainly motivated by differences in excises, not in VAT. Thirdly, harmonization would improve the efficiency of exchange. Fourthly, if fuel and motor vehicles are used in the production process, harmonization of the related excises reduces intercountry distortions from excise-induced differences in cost structures.

\section{(b) Individual Excises}

\section{Tobacco Taxes}

Tobacco taxes in the EU are the highest in the world. The total tax (excises and VAT) on cigarettes (approximately 95 percent of manufactured tobacco consumption) is, on average, 75 percent of the retail price, which equals 300 percent of the tax-exclusive price. ${ }^{81}$ The high taxes on tobacco are mainly rationalized as a charge for the social cost of smoking, although the principle of consumer sovereignty indicates that this argument is not very persuasive if information failures are few ( 90 percent of people are aware of the health risks of smoking) and external costs (damage done to the health of other people) are better taken care of through bans on smoking in public areas. For the US, the gross social costs of smoking have been estimated at 43 cents per pack of cigarettes and the net costs (netting out healthcare expenditures resulting from smokers' premature deaths) at 16 cents (Manning et al., 1989). Similar figures for the EU would imply that tobacco excises (Table 6) far exceed net social costs.

The debate in the EU on the tobacco excise centers on the most appropriate balance between specific and ad valorem taxation. Southern Member States favor the ad valorem rate, which tends to protect their cheap, home-grown tobaccos. Northern Member States, on the other hand, have a preference for specific taxation, which probably better reflects the social costs of smoking, may be more effective in reducing the level of tobacco consumption and involves less trade diversion. ${ }^{82}$

The locked-in positions have led to a compromise under which the specific rate can range from 5 percent to 55 percent of the retail price (inclusive of tax) of the most popular brand of cigarettes. In addition, the total excise - specific and ad valorem - should be at least 57 percent of the retail price. Beyond that, the minimum applicable VAT rate should be 15 percent (the agreed minimum of the VAT rate approximation directive). As a result, the total tax on a pack of 20 cigarettes varies widely in the EU, ranging from 5.64 euro in the UK to 1.33 euro

\footnotetext{
${ }^{81}$ In comparison, the VAT rate of, on average, 19.4 percent in the EU, which is also calculated on the price exclusive of tax, seems very modest.

${ }^{82}$ For a recent review and evaluation of tobacco taxes in the OECD, see Cnossen and Smart (2002).
} 
in Spain (Table 6). Not surprisingly, bootlegging (tax-base snatching) is a major problem. Recently (Directive 2000/10/EC), it has been agreed that the total excise should not be less than 60 euro per thousand cigarettes (or 95 euro if Member States do not comply with the 57-percent rule) ${ }^{83}$ This implies a heavier dose of specific taxation. The increase in total tax also increases the smuggling problem, particularly when the central and eastern European countries are admitted to the EU.

\section{Alcohol Excises}

Harmonization of the alcohol excises is mostly of the spontaneous kind. Over the years, the EU has drifted in the direction of the lowest common excise rate. As Table 6 indicates, in eight Member States the beer excise is 3 euro cents or less per liter. Seven Member States do not levy any excise on still wine and in France the excise is 3 euro cents. Excise duties on a bottle of spirits range from 1.94 euro in Italy to 15.45 euro in Sweden, but in 10 Member States the duty level is 5 euro or less. Perhaps the erosion of the alcohol tax base is not surprising, since the EU is the most important wine-growing region and beerproducing region in the world. ${ }^{84}$ With only one-eighth of the world's population, the EU consumes one-half of all alcohol produced in the world. Although the European Court of Justice has banned the most flagrant forms of discrimination against out-of-state producers (Cnossen, 1987), Member States still protect their national vinicultures by applying excise rate structures that distinguish between still and sparkling wines and between ordinary and fortified wine, instead of basing them on alcohol content.

While two drinks per day are said to be good for you (suggesting that these drinks should not be subject to excise), excessive alcohol consumption entails social costs, such as vandalism, traffic accidents and violent behavior (whose costs should be internalized through the alcohol excise). It is not possible, however, to implement an alcohol excise tax structure that differentiates on the basis of the volume consumed. The European Commission (1989) has suggested that minimum rates should be set, supplemented by target or reference rates for medium-term harmonization. Broadly, as indicated by the verdicts of the European Court of Justice (Case 170/78 ECR (1985)), the relative strength of alcoholic beverages is taken as the criterion in judging whether equality in competitive conditions within Member States is observed. Thus, large differences between Member States are still possible, resulting in substantial

\footnotetext{
${ }^{83}$ In due course, the EU will also have to think about the design of an excise on drugs, such as marijuana and cocaine. Although less addictive than nicotine, so far these drugs are illegal although widely used. As The Economist (July 28, 2001) argues persuasively, legalization has more advantages than disadvantages, even though the consumption of the drugs would rise.

${ }^{84}$ The taxation of alcoholic beverages (and tobacco) is related to the Common Agricultural Policy (CAP), which subsidizes the production of grapes, grains and hops (and tobacco).
} 
bootlegging, e.g. between the UK and France, between Sweden and Denmark and between Denmark and Germany. ${ }^{85}$

\section{Road User Charges and Taxes}

Road (and similar transport) services resemble goods produced in the private sector that are used optimally when their price, commonly referred to as the economic user charge, equals the costs of operating the road network. Road user charges should contain charges for efficient road use, congestion and road damage, as well as charges for other externalities, such as pollution, noise and accidents, the VAT and additional taxes for revenue or equity reasons. Road user charges can be set to cover the total costs of operating the network or the difference between the social marginal cost and the average private cost of road use. Newbery (2002) identifies the conditions under which the two are equal. Charging efficient prices will recover the total costs of the road network if the marginal cost of road expansion is constant.

The major forms of road user charges and taxes that are used in the EU comprise taxes on fuel, taxes on motor vehicle purchases and license fees. Of these charges and taxes, the gasoline excise is the highest in all Member States, averaging 51 euro cents per liter in the EU (Table 6). According to Newbery (2002), this is about the right amount for the pure road charge and green tax element. ${ }^{86}$ On this basis, Belgium, Ireland and Italy are taxing gasoline at about the right rate, but the UK, Germany, the Netherlands, France and Finland are overcharging road users. Furthermore, Newbery estimates that the additional tax (currently, purchase tax and license fee) that might be justified is only a further 30 percent on top of the road charge and green tax element.

In most Member States, then, the pricing function of road user charges and taxes is overshadowed by their role as general revenue-raisers. Often, the fallacious argument is used that the higher tax level is needed to finance healthcare and education. In fact, however, governments are exercising their market power to drive up the scarcity price of the natural monopoly under their control. Much more can be done, moreover, to improve the design of road user charges and taxes. In particular, a system of electronic road pricing is likely to be a more efficient way of dealing with road use than the existing blunt instruments of fuel excises and public transport subsidies.

\section{Green Taxes}

Fossil fuel taxes are also used to arrest global warming caused by the emission of carbon dioxide. Although the European Commission's (1991) proposal for a

\footnotetext{
${ }^{85}$ The problem is particularly acute between Denmark and Sweden, where about a quarter of spirits consumed are bought outside the consumer's own Member State (European Parliament, 2001).

${ }^{86}$ However, most Member States are undertaxing diesel relative to gasoline. Diesel delivers more kilometers to the liter and should therefore be taxed higher instead of lower than gasoline.
} 
carbon tax was never approved (Pearson and Smith, 1991), several Member States have restructured their excise systems in line with environmental objectives. Existing taxes have been redesigned to favor less-polluting products (e.g. unleaded vs. leaded gasoline) and new taxes have been introduced to raise the price of polluting products or processes (e.g. on fertilizers, pesticides, sulfur, disposable containers, basic chemicals and batteries). Taxes on carbon are now on the statute in Denmark, Finland, the Netherlands and Sweden. In all of these Member States, the revenue is used to reduce labor income taxes, particularly employers' social security contributions. ${ }^{87}$

On the basis of a comprehensive survey, Barde and Braathen (2002) conclude that green taxes and other environmentally related levies in EU Member States (and other OECD countries) still exhibit a number of shortcomings. In most cases, the externality-tax linkage is weak, the rates are low, the bases are riddled with exemptions (e.g. for coal, often subsidized), taxes overlap with regulations, and international coordination, required to contain border-crossing externalities, is not forthcoming.

\section{TAXES ON LABOR}

Greater labor market participation is high on the political agenda in most EU Member States. Low participation and high unemployment are a waste of human potential and national product and one of the root causes of most prevailing social and economic inequality in the EU. Long-term unemployment (approximately half of total unemployment, against only 10 percent in the US), creates considerable political tensions. It is heavily concentrated among lowskilled workers. These workers tend to develop a state of 'learned helplessness,' as they lose their working habits and their motivation to work. Greater labor market participation is also important in the face of an aging population in most Member States.

\section{Labor Participation and Effective Tax Rates on Labor}

As Table 7 indicates, the labor force participation rates of 13 Member States are lower than the rate is in the US (in addition, workers in the EU put in fewer hours - totaling some 9 weeks per annum). In 2000, more than three out of four persons of working age were gainfully employed in the US, but less than three out of five in Italy. Particularly, Germany, France, Spain and Italy, jointly accounting for 60 percent of the labor force in the EU, have low participation and high unemployment rates. The Netherlands' unemployment rate of 2.7

\footnotetext{
${ }^{87}$ See Section V. For a wide-ranging review of the theory and practice of environmental taxation, see also Bovenberg and Cnossen (1995).
} 


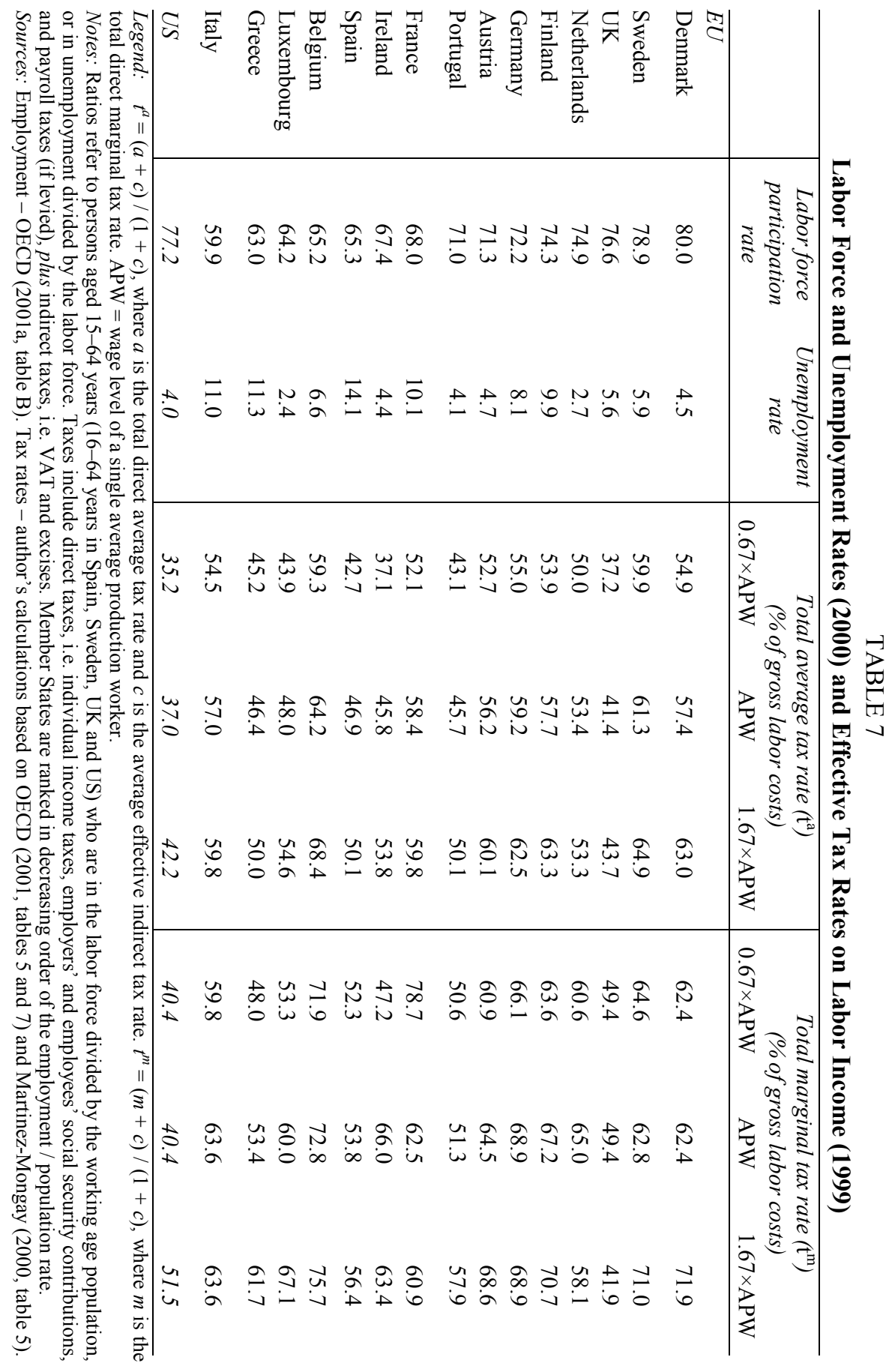


percent is the lowest in the EU, but its participation rate of 74.9 percent is lower than the US rate. Part of unemployment in the Netherlands is disguised in disability schemes. ${ }^{88}$ Denmark and Sweden are the only EU Member States that have higher participation rates than the US rate and relatively low unemployment rates.

In view of these dismal statistics, Make Work Pay (MWP) policies are high on the political agenda in various Member States, such as Belgium, France and Ireland (OECD, 2000). Tax reform - e.g. in the form of earned income tax credits (EITCs) - is considered one of the appropriate instruments to attain the objectives of MWP policies. It is believed that the high effective tax rates on labor, particularly at the lower end of the income distribution, have a detrimental effect on labor supply (by reducing after-tax wages) ${ }^{89}$ and demand (by raising labor costs). Accordingly, it has been proposed that taxes on labor should be lowered. The European Commission (1996), for instance, has proposed switching the tax burden from labor to consumption, capital and/or energy.

Table 7 also shows the level of the total average and marginal tax rates on labor in the various Member States. The total average tax rate measures total taxes relative to the employer's total pre-tax labor cost, while the marginal tax rate is defined as the total tax liability on an additional unit of gross labor income. Total taxes include social security contributions (by employers and employees), individual income taxes and consumption taxes. ${ }^{90}$ All these taxes drive a 'wedge' between the employer's gross labor cost (i.e. gross wages plus employers' social security contributions) and the worker's after-tax disposable income (including child benefits, if any, paid by government); hence, all should influence the demand and supply of labor. The tax wedges are given for single workers ${ }^{91}$ with income levels corresponding to 67 percent, 100 percent and 167 percent of the gross labor cost of an average production worker (APW). The 67 percent APW income level is of interest because it is close to the minimum wage, which tends to be 50 percent of the APW income level in most Member States. ${ }^{92}$ In turn, the minimum wage is close to the acceptable social minimum level of income, to which social benefits are related.

\footnotetext{
${ }^{88}$ Adema (1999) shows that disability spending in the Netherlands, at 4.1 percent of GDP (three times higher than in Germany), is the highest in the EU.

${ }^{89}$ This assumes that the uncompensated wage elasticity is positive. Generally, the elasticity is zero for primary males, but positive elasticities have been recorded for married women and part-time workers.

${ }^{90}$ That taxes should include consumption taxes is argued persuasively by OECD (1995) and Nickell (1997). As argued above, social security contributions should also be included, because there is hardly an actuarial link between contributions and benefits.

${ }^{91}$ OECD (2001b) also gives total average and marginal tax rates at various earnings levels for single workers with two children and married workers without children and with two children.

${ }^{92}$ Below the 67 percent level, the average tax rate is a less reliable indicator of the tax burden, because various income and housing support benefits may be significant sources of income. The same applies to earnings levels higher than the $1.67 \times \mathrm{APW}$ income level, because income from owner-occupied housing and savings then become important.
} 
The most striking feature of the table is how high the effective tax rates on labor are in most Member States. At the average earnings level in Belgium and Sweden, unmarried workers without children pay over 60 percent of their annual wages in taxes. (For every euro of an APW's gross wage in Belgium, only about 36 euro cents is freely disposable.) In eight Member States, the percentage is higher than 55 percent. Two large Member States - Germany and France - have among the highest taxes on labor in the EU. In only one Member State - the UK - does the average tax rate (of 41 percent) at the APW earnings level come close to, albeit still exceeding, the average tax rate of 37 percent in the US. Nevertheless, there is no obvious link between the level of taxation, either overall or on labor, and participation rates (or unemployment) among Member States. ${ }^{93}$

A comparison of the figures in Table 7 with the results in The OECD's Jobs Study (1995) and table 1 in Sørensen (1997), moreover, indicates that, since 1992, the total average tax rates at the APW as well as at the $0.67 \times \mathrm{APW}$ earnings level (just above the minimum wage) have increased in most Member States. ${ }^{94}$ Increases in social security contributions and consumption taxes have been used to finance, among others, old-age benefits and a reduction in individual income tax rates for top-rate earners (above the $1.67 \times \mathrm{APW}$ earnings level).

As expected, Member States with high average tax rates also have high marginal tax rates. In Germany, taxes absorb 69 euro cents of an APW's pay rise of 1 euro, compared with 40 euro cents in the US. In 11 Member States, the after-tax wage of an additional hour of work is 40 percent or less of the beforetax wage. A comparison of the total average and marginal tax rates between levels of APW income shows how little progression the tax system exhibits. ${ }^{95}$ The progressivity of the individual income tax is blunted considerably by the proportionality or regressivity of the social security contributions (generally levied at flat rates without an exempt threshold ${ }^{96}$ ) and the consumption taxes.

\footnotetext{
${ }^{93}$ Interestingly, in general, small Member States tend to have lower levels of unemployment than large Member States. This suggests that institutional structures matter - structures such as coordinated national wage bargaining in small Member States that achieve outcomes closer to competitive markets than strong unions and decentralized wage bargaining in large Member States (Hoel (1991), quoted in Disney (2000)). Furthermore, labor unions in small Member States are more likely to internalize the government's budget constraint.

${ }^{94}$ The OECD's Jobs Study notes that taxes on labor had already started to increase as early as 1978.

${ }^{95} \mathrm{At}$ a given income level, the progressivity of the tax system can also be measured by the coefficient of residual income progression (CRIP), i.e. the percentage increase in after-tax income if gross labor costs rise by 1 percent. In other words, in the notation of Table 7, CRIP $=\left(1-t^{m}\right) /\left(1-t^{a}\right)$. The tax system is proportional if this elasticity equals 1 , and the further the parameter falls below unity, the higher is the degree of tax progressivity. In all EU Member States bar Ireland, this elasticity is 0.75 or higher at the APW earnings level. The CRIP is very high in Sweden, France and Portugal.

${ }^{96}$ In addition, all Member States have income ceilings above which social security contributions are not payable. Generally, however, these ceilings are applicable to income levels higher than $1.67 \times \mathrm{APW}$ earnings.
} 
Against this background, the OECD's understatement in 1995 still appears relevant in 2001 - that it would be surprising to conclude that taxation at such high average and marginal tax rates has little impact on labor markets. Accordingly, it seems worthwhile to revisit the OECD's earlier analysis on taxation and unemployment. ${ }^{97}$

\section{Alternative Forms of Taxation and Employment}

Average and marginal tax rates have quite opposite effects on employment. An increase in the average tax rate reduces consumption possibilities and may therefore induce workers to work more (income effect), whereas an increase in the marginal tax rate may increase the attractiveness of leisure (substitution effect). Average and marginal tax rates, moreover, tend to have opposite effects on wage-setting behavior in noncompetitive labor markets. Generally, an increase in average tax rates will fuel demands for higher wages. Greater tax progressivity, on the other hand, will dampen wage demands (Lockwood and Manning, 1993) and may encourage part-time work and boost the labor participation of second earners if the individual is the tax unit.

The interaction between tax structures and social benefits also affects the supply and demand for labor. High social benefits raise replacement rates (the ratio of income out of work to earnings in work) for the low-skilled as well as for workers eligible for retirement (unemployment trap). In addition, the withdrawal of out-of-work benefits upon entry to the labor market involves very high effective tax rates (poverty trap), which lower the incentives for schooling and job searching. MWP policies, therefore, seek to compensate the loss of out-ofwork benefits with the provision of in-work benefits.

If tax reform is to promote employment by reducing the tax burden on labor, two conditions must be met (Bovenberg, 1995). First, the overall tax burden should not rise. Importantly, this overall tax burden should be defined to include 'implicit' taxes (collected elsewhere in the economy but ultimately borne by labor in the form of lower real after-tax wages) and the excess burden of taxation (the economic cost over and above the tax yield). Secondly, the distribution of the tax burden should be moved away from workers to people outside the labor force, i.e. recipients of income transfers and pensions, and owners of capital and natural resources. ${ }^{98}$

\section{(a) Value Added Taxes}

Since some consumption is financed out of capital income, a revenue-neutral shift from labor taxes to consumption taxes would reduce the tax burden on labor

\footnotetext{
${ }^{97}$ This analysis is found in chapter 4 of The OECD's Jobs Study (1995).

${ }^{98}$ The tax burden can also be shifted to the future by increasing the fiscal deficit, but this has become more difficult in light of the limit imposed by the Maastricht Treaty.
} 
in the short run..$^{99}$ If unanticipated, the increase in the consumption tax would be in the nature of an implicit one-off wealth tax (Auerbach and Kotlikoff, 1987), which would enhance overall efficiency and which would be borne primarily by older generations who own most wealth. ${ }^{100}$ Another advantage of the switch is that the excess burden of consumption taxes tends to be smaller than the excess burden of wage taxes.

In the presence of nominal wage rigidities, furthermore, the increase in consumption taxes would, initially, be borne by workers rather than employers. This would also increase the demand for labor. This increase can be long-lasting if the natural rate of unemployment depends on past employment (hysteresis). ${ }^{101}$ Similarly, the switch would have a favorable effect on the labor supply of people on unemployment benefits, because it would reduce their net disposable income and thus induce them to reenter the labor force (income effect). The success of a switch from taxes on labor to taxes on consumption depends, of course, on the extent to which demands for compensating adjustments in wages and social benefits can be held at bay. ${ }^{102}$ Unemployment would not fall if unemployment benefits are indexed for the effects of the tax switch.

Tax switches may be expected to have different effects on different kinds of workers and patterns of work. Research has shown that the labor supply elasticities of married women and part-time workers are higher than the elasticities of males and full-time workers. ${ }^{103}$ With this in mind, Hutton and Ruocco (1999) have examined the employment effects of the increases in VAT and the reductions in income tax in the last decade in Germany, Italy and the UK, as well as the opposite switch in France. They find that this tax policy has helped offset rising unemployment in Germany and Italy and reinforced the downward movement in unemployment in the UK, through greater participation by women and more part-time work by both men and women. In France, the opposite tax policy and employment outcomes have been experienced. The theoretical underpinning of their findings is that a proportional VAT is less distortive to the leisure-consumption choice than an equal-yield progressive labor income tax. This switch would also alter the tax burden distribution, of course, and might, initially, increase unemployment before the rise in employment sets in.

\footnotetext{
${ }^{99}$ This effect would only be temporary if (e.g. in insider-outsider models) taxes are borne by labor in the long run. However, in structural models, which emphasize the role of asset markets, the effect could be permanent.

${ }^{100}$ An unanticipated tax would be time-inconsistent, of course, and hurt government's reliability.

${ }^{101}$ Hysteresis may occur if the working skills of the unemployed erode rapidly or if unions do not take the interests of the unemployed into account when bargaining about wages.

${ }^{102}$ Furthermore, Bovenberg (1996) has pointed out that, in the short run, a switch from a source- or originbased labor income tax to a destination-based consumption tax would have a beneficial effect on trade, which might stimulate employment in the export sector.

${ }^{103}$ The labor supply elasticity of men working full time has been shown to be zero (Pencavel, 1986).
} 
Rather than focusing on the VAT in general, Sørensen (1997) has examined the effect of the introduction of a low-rate VAT on labor-intensive personal services that compete with services supplied from the informal economy. Emphasizing that this approach is not the solution to the European unemployment problem, his second-best optimal analysis suggests, nevertheless, that some beneficial employment effects would ensue in markets where these services are substitutes for leisure and where labor supply is not very elastic. Various Member States have acted upon this finding by imposing a reduced VAT rate on a specified list of labor-intensive services, such as construction, renovation, cleaning, childcare and hairdressing. ${ }^{104}$

\section{(b) Taxes on Capital}

Whether capital is undertaxed relative to labor is difficult to say. Gordon (2000) argues that capital should not be taxed at all. Efficiency is compromised because (anticipated) capital income taxes reduce capital accumulation, thereby shifting the burden of the tax onto labor. If so, the switch would be detrimental to production efficiency (and equity), because it would be better to tax labor directly. In open economies, moreover, capital can escape the tax burden by moving abroad.

But this discussion assumes that capital is perfectly mobile. This is so with respect to financial capital, but not with respect to physical capital, which tends to be rather immobile internationally. The discussion also assumes that labor is homogeneous, which bypasses the distinction between skilled and unskilled labor. While skilled labor is more likely to be complementary to capital, unskilled labor can be regarded as a substitute for capital. In theory, taxes that increase the relative price of capital can raise the demand for unskilled labor. Finally, an exception should be made for location-specific rents, which can be taxed away without harming efficiency.

The OECD (1995) believes that the optimal level of taxation on capital has little policy relevance to unemployment. In the long run, capital is likely to be mobile and thus able to escape the burden of differentially higher taxes. Taxing capital to increase demand for unskilled labor may be suicidal in a modern economy. Exceptionally, some increase in the tax burden might be achieved through policy coordination, because the EU-wide capital supply elasticity is lower than that for individual Member States. But, on balance, efforts should probably be concentrated on protecting the capital income tax base against erosion, particularly by mobile international financial services.

\footnotetext{
${ }^{104}$ Ebrill et al. (2001) have drawn attention to the negative distributional consequences of such measures if small VAT-exempt firms were to lose business. In addition, the administrative complexities - delineating lower-taxed services from services subject to the standard rate - are substantial. Beyond that, part of the benefit of the incentive is likely to leak away to consumers of the lower-taxed services.
} 


\section{(c) Energy Taxes}

Another possibility would be to shift the tax burden on labor to taxes on fossil fuels, whose use has a detrimental effect on the environment. ${ }^{105}$ In an early, optimistic view, it was thought that this switch might yield a 'double dividend' if the revenue from environment-improving taxes were used to lower labor-marketdistorting income taxes. However, this view has lost much of its appeal (Goulder, 1995). While a better environment is a public good, abatement costs are borne by the private sector. These abatement costs will be higher, the higher is the reduction in energy use. But a high degree of success implies little revenue with which to lower labor income taxes. ${ }^{106}$ Thus, there is a fundamental trade-off between beneficial environmental effects and favorable employment effects.

Apart from the additional substitution effect away from energy-intensive products, the effect on employment of a switch from labor taxes to taxes on energy used for final consumption purposes is broadly the same as the effect of an increase in VAT. The energy content of most final consumption goods does not vary greatly. Household fuels and motor fuels are, obviously, the exceptions (Pearson and Smith, 1991). The success of the switch would depend on the extent to which consumers outside the labor force are not compensated for the increase. The switch is regressive, particularly in northern Member States, which are heavy consumers of household fuels. Nevertheless, the Netherlands and the Scandinavian countries have successfully introduced separate taxes on household fuels, subject to an exemption for a basic volume.

If energy taxes are imposed on producers on an origin basis, the welfare effect would only be beneficial if the excess burden of the new tax is smaller than the excess burden of labor income taxes (Poterba, 1993). Whether this is so is not obvious, but it may be presumed that a broad-based consumption tax, such as the VAT, would have a lower excess burden than a narrow-based energy tax. The trade-off between excess burdens is particularly acute in the EU Member States in view of their high tax levels. At current levels of taxation, governments can ill afford the substitution of distortionary but revenue-productive taxes by less distortionary taxes with lower yields.

Again, only some success can be expected, to the extent that the energy tax is shifted to people outside the labor force, i.e. capital owners or resource owners. Empirical evidence suggests that capital and energy are complementary. Capital is thus likely to bear part of the tax burden on energy inputs, at least in the short term. In response, it may escape the tax burden by moving to countries without energy taxes. As a consequence, a lower capital stock and lower energy demand reduce labor productivity, thereby raising unit labor costs. Tax-exporting to

\footnotetext{
${ }^{105}$ For a rigorous analysis of the trade-offs between reducing pollution and promoting employment, see Bovenberg (1995).

${ }^{106}$ Polluters, moreover, will demand compensation for their loss of property rights in pollution (Bovenberg, 1999).
} 
foreign resource owners would be another option. Generally, however, no single consuming country can depress the supply price below the prevailing market price. Hence, international coordination would be required to shift an energy tax to resource owners.

\section{(d) Social Security Contributions and Income Taxes}

The demand for labor might be favorably affected by a switch from employers' social security contributions (which raise labor costs) to employees' contributions (which reduce take-home pay), as long as it did not lead to an equal rise in after-tax wage demands. Whether or not this happens depends on the relative elasticities of demand and supply for labor, as well as on other factors that impede wage flexibility, such as the minimum wage, ${ }^{107}$ and the way in which unemployment benefits are taxed. If after-tax wages did not change, then labor costs would decline by the full amount of the reduction in employers' contributions. Other things being equal, this should increase the demand for labor and employment. Studies for some Member States (OECD, 1995) provide evidence that changes in employers' contributions do indeed have a greater impact on unemployment than changes in employees' contributions. Accordingly, some Member States have altered the composition of the contributions by employers and employees. ${ }^{108}$

The tax burden on low-skilled workers could be reduced by abolishing the income ceilings in social security contribution schemes ${ }^{109}$ and using the revenue to introduce a threshold below which contributions would not be payable by the employer, the employee or both. In the absence of a link between contributions and social benefits, it might even be possible to finance benefits out of general revenue (Denmark) or, say, through an increase in the VAT. Nickell and Bell (1996) argue that a small positive effect can be expected from a reduction in social security contributions by the low-skilled if their wages are inflexible (in the event, contributions would not be wholly borne by labor). The disadvantage of this tax reduction is that, as the authors point out, the increase in take-home pay of the low-skilled would reduce the incentive to acquire training for the lowskilled as well as for those further up the pay scale whose taxes would have to be increased.

Others (e.g. van der Ploeg, 1998) have advocated an earned income tax credit (EITC) for reducing poverty while maintaining work incentives. Empirical

\footnotetext{
${ }^{107}$ Note the equivalence between a minimum wage and a tax on employers for hiring workers who would otherwise be paid less than the minimum wage, with the proceeds transferred to the workers.

${ }^{108}$ Nevertheless, in the EU as a whole, the pattern of social security contributions has changed little since 1990. Employers' contributions are still twice as high as employees' (OECD, 2001).

${ }^{109}$ Furthermore, contributions could also be levied on social benefits. In the Netherlands, social security contributions for old-age and widow pensions and medical and disability schemes are levied on total taxable income, including social benefits. This is also the case in Denmark, which finances social benefits out of general revenue.
} 
research in the US (Scholz, 1996; Eissa and Liebman, 1996) has found that the EITC (designed as a credit against income tax liability paid to low-income families with children) has a negative effect on hours worked. But, perhaps more importantly, it has unambiguously positive labor market incentives on the decision about whether to work. The UK and Ireland have similar 'family credit schemes', and several EU Member States offer mixtures of deductions for workrelated expenses, childcare costs and other more general forms of in-work tax credits (Whitehouse, 1996). Generally, the phase-out of the EITC is important. An abrupt phase-out produces a disincentive to increase hours conditional on participation (the notorious poverty trap). A gradual phase-out, on the other hand, reduces the positive effect on participation and is more costly to revenue.

\section{(e) Evaluation}

This review and update of The OECD's Jobs Study (1995) indicates that little can be done to increase employment through the tax system. ${ }^{110}$ According to OECD (1995), the scope for shifting the tax burden away from labor to other tax bases is either 'worthwhile but limited (in the case of consumption), possibly undesirable (capital), and probably desirable but with at best modest consequences for employment (energy)'. Tax-shifting within the earnings distribution is also of doubtful efficacy, because it would move the wedge up the pay scale, where it would aggravate distortions at a higher wage level. The OECD's (1995) bottom line is that the tax burden on the working poor can only be mitigated by switching it to the nonworking prosperous old.

This cloud has a few silver linings. First, if labor or product markets are not competitive or labor supply not completely inelastic, some shifting to consumers outside the labor force, capital owners or resource owners may be possible (although the effect is unlikely to be large). Secondly, tax reforms targeted at married women and part-time workers who have positive labor supply elasticities will increase employment. Thirdly, predictable positive effects on labor supply also occur among low-income families, particularly single parents and singleearner couples, if an optimal mix of tax credits (and welfare benefit schemes) is designed (Disney, 2000).

But, on the whole, the effect of the restructuring of tax systems to promote employment is meager. In a closely written assessment, Haveman (1996) concludes that his discussion of six central strategies ${ }^{111}$ for simultaneously reducing the 'poverty trap', providing adequate income support and increasing

\footnotetext{
${ }^{110}$ For a comprehensive review and evaluation of a large number of studies on the impact of tax and welfare policies on employment and unemployment in OECD (including EU) countries, see Disney (2000).

${ }^{111}$ The six central strategies are four income support regimes (a credit income tax, a negative income tax, a basic income guarantee and an EITC) and two labor market strategies (a wage rate subsidy and employer-based marginal employment subsidies). For an evaluation of low-wage job subsidies, a basic income guarantee and a negative income tax, see also Minford (1996).
} 
both labor supply and labor demand carries one clear lesson, which is that ' $[\mathrm{n}] \mathrm{o}$ single policy is capable of both assuring adequate income support to those without sufficient earnings (i.e. poverty reduction) and stimulating an increase in the employment of low-skilled workers'. Furthermore, he notes that ' $[\mathrm{t}] \mathrm{he}$ "iron law" of income support needs to be again emphasized: an income guarantee assuring all citizens of an "adequate" level of living financed via an individual income tax requires a structure of marginal tax rates implying substantial work disincentives. And, the higher the guarantee, the more severe are the work disincentives'.

The message is that the tax system cannot be used to compensate for the failures of the social security system. If a dent is to be made in the high unemployment rates, the trade-off between in-work benefits (poverty trap) and out-of-work replacement rates (unemployment trap) has to be reviewed. This trade-off is acute among low-income earners, but it is also inherent to many disability and early-retirement schemes. High replacement rates of incomes in and out of work and high effective marginal tax rates (including welfare benefit withdrawals) faced by (potential) workers reduce the incentives to enter the labor market, improve skills, increase effort and work longer hours.

Finally, as emphasized by Bovenberg (1995), an essential element to success in reducing unemployment lies in greater real wage and relative wage flexibility. Job security, seniority systems, regulated pay scales and minimum wages all amount to implicit taxes on labor. Furthermore, '[t]raining and acquiring skills constitute the keys for breaking the vicious circle of poverty and unemployment and hence improve the trade-off between equity and efficiency by reducing the need to use distortionary instruments to redistribute income' (Bovenberg, 1995).

The interaction between the labor market and each Member State's specific economic and social institutions underscores the need for country-specific measures to combat unemployment. This suggests that there is little or no role at the central EU level for solving the unemployment problems of the Member States. On the contrary, EU-wide coordination of taxes on labor, benefit schemes and labor market regulations would most likely exacerbate the impact of existing distortions and structural rigidities in the labor market.

\section{TAXES ON CAPITAL}

In contrast to taxes on consumption, the EU Treaty provides little guidance on the harmonization of taxes on capital in the internal market, ${ }^{112}$ despite the equivalency with consumption taxes (Section II) and the continuing integration of capital markets. Nevertheless, in the course of the years, the European

\footnotetext{
${ }^{112}$ According to Articles 100 and 101 (old), laws, including income tax laws, should be approximated if required for the functioning of the single market. This mandate is not as strong as the obligation in Article 99 (old) to harmonize sales taxes and excises.
} 
Commission has made various proposals to bring the capital income tax systems closer together. ${ }^{113}$ The proposals have regard to (corporation) tax structures, bases and rates, the promotion of cross-border cooperation between (related) enterprises, tax competition and tax administration.

Early on, in 1975, a proposal was made for the EU-wide introduction of an imputation system, followed, in 1989, by a draft proposal for the harmonization of profit determination rules. However, both measures failed to receive the support of the Member States. The same fate befell a minimum 15 percent source tax on interest proposed first in 1989 and again in 1998 in combination with the alternative of a notification procedure.

A number of less ambitious measures were adopted, however, to promote cross-border cooperation between enterprises. These measures include the parent-subsidiary directive (no withholding taxes on intercompany dividend payments - Directive 90/435/EEC), the merger directive (suspension of the taxation of capital gains arising on the cross-border transfer of assets - Directive 90/434/EEC) and the arbitration convention (solution of double taxation issues in connection with adjustments to transfer prices - Directive 90/436/EEC). Proposals for an interest/royalty directive (no withholding taxes on intercompany payments - (COM(1998) 67 final) and a directive on intragroup losses (COM(90) 595 final) still await approval.

Furthermore, a mutual assistance directive (Directive 77/799/EEC) was adopted in 1997, providing for the exchange of information between Member States. In the same year, a nonbinding Code of Conduct on Business Taxation, purporting to curtail 'harmful tax practices' by Member States, ${ }^{114}$ was subscribed to by the Member States, followed by a shame list issued by the Primarolo Group which identified 66 malpractices (connected to the tax-favored provision of financial services to third parties, intra-group financing and the provision or licensing of intangible property in return for royalty payments).

The most far-reaching proposals for the harmonization of the corporation income taxes, in three phases, dealing with structural, base and rate issues, were made by the Ruding Committee (1992), but they did not leave the drawing board. ${ }^{115}$ Recently, picking up from the Ruding Committee, the European Commission (2001) issued a voluminous report on corporate taxation. The report, referred to as the Bolkestein Report, lists a large number of (alternative) options for tax coordination in the form of targeted measures and comprehensive solutions to reduce cross-border investment distortions and taxpayer compliance costs.

\footnotetext{
${ }^{113}$ For useful reviews with references to the various European Council and Commission proposals, see Easson (1992) and European Parliament (2001).

${ }^{114}$ For an in-depth legal analysis, see Bratton and McCahery (2001), who also pay attention to economic and political aspects.

${ }^{115}$ For reviews and evaluations of the Ruding Committee Report, see Vanistendael (1992), McLure (1992), Devereux (1992), Gammie (1992) and Cnossen and Bovenberg (1997).
} 
Broadly, most of the above-mentioned proposals fall into two categories: proposals that address tax structure issues and proposals that deal with barriers to cross-border cooperation. As background to the discussion of the various proposals, this section starts with a review and analysis of the capital income tax systems of the Member States. Next, the comprehensive proposals of the Bolkestein Report are evaluated. It is concluded that the proposals ignore the distortions of capital income tax systems within Member States, which must be solved if distortions between Member States are to be mitigated. Accordingly, an alternative reform agenda is sketched.

\section{Review and Analysis of Capital Income Tax Systems}

This review of capital income tax systems in the Member States falls into three parts: a survey of corporation tax regimes, an analysis of the (divergent) treatment of equity and debt income, and a discussion of effective tax rates.

\section{(a) Survey of Corporation Taxes}

Corporation taxes (CTs) in the EU (and elsewhere) are commonly distinguished depending on whether and to what extent they reduce the double tax - CT and individual income tax $(\mathrm{PT})$ - on distributed profits, i.e. provide dividend relief. No relief is provided under the so-called classical system of CT. By contrast, imputation systems provide full or partial relief by permitting shareholders a tax credit against their PT for the CT that can be imputed to the dividends (grossed up by the tax credit) received by them. ${ }^{116}$ The double tax can also be mitigated by subjecting dividend income to a separate or schedular PT rate lower than the top PT rate.

Table 8 shows the CT systems that are found in the EU Member States. Nominal tax rates range from 16 percent in Ireland to 41.1 percent in Germany. Furthermore, Member States have the following CT systems:

- Six Member States employ the imputation system. Usually, the gross-up and tax credit are expressed as a fraction of the net dividend. ${ }^{117}$ Finland and Italy are the only Member States that permit a full tax credit against the PT for the $\mathrm{CT}$ attributable to shareholder dividends. In the UK, the relief is so small merely one-ninth of the net dividend - that the system approximates the classical system.

\footnotetext{
${ }^{116}$ Equivalent relief can be provided under a split-rate or dividend-deduction system. For the classical analysis of dividend-relief systems, see McLure (1979). For a more recent discussion, see also US Department of the Treasury (1992), and for a survey of OECD countries, see Cnossen (1997).

${ }^{117}$ Alternatively, the relief can be expressed as a percentage of the CT (indicating the extent to which the double tax is mitigated) or as a percentage of the grossed-up dividend (representing the comparable tax-inclusive PT rate).
} 
- Six Member States provide dividend relief at the shareholder level by taxing distributed profits at a schedular, usually flat, PT rate separate from the PT on other income. Germany and Luxembourg tax dividends at half of the PT rate applicable to other income (simply by exempting half of dividends received).

- Two Member States exempt dividend income in the hands of individual shareholders. The Netherlands levies a net wealth tax instead, called presumptive capital income tax. ${ }^{118}$ A net wealth tax is also found in five other Member States (see Table 8), although these states tax dividend income (and capital gains) under their PTs too.

- One Member State - Ireland - subjects dividend income fully to the twin yoke of the CT and the PT (classical system), although rates are so low that the total tax on current distributions is less than the total tax in many other Member States.

The imputation system is the most structured form of relief in light of the normative implication of the comprehensive income tax that the taxation of corporate profits should be fully integrated with the PT of shareholders. ${ }^{119}$ Imputation reduces the excess $\mathrm{CT}+\mathrm{PT}$ burden on profit distributions in proportion to the marginal PT rates of shareholders. ${ }^{120}$ In contrast, under the schedular PT rate schemes, the relief is proportionately greater for high-incomebracket PT-payers than for low-income-bracket PT-payers. ${ }^{121}$ Of interest is that the full imputation system in Finland is equivalent to the dividend-exemption systems in Greece and the Netherlands. In these countries, retained and distributed profits bear the same $\mathrm{CT}(+\mathrm{PT})$ burden (if capital gains taxes are

\footnotetext{
${ }^{118}$ To preserve some semblance to the income tax, the presumptive return on shares is set at 4 percent of their market value; this return is taxed at 30 percent. The tax base of the presumptive capital income tax also includes debt instruments, real estate (except if owner-occupied) and bank deposits. Like dividends, interest and rental income are not taxed at the individual level. Exceptionally, the returns on the equity of the selfemployed or held in closely-held corporations are taxed on an actual, not a presumptive basis. For a review and evaluation of this new tax, see Cnossen and Bovenberg (2001).

${ }^{119}$ See Musgrave and Musgrave (1984). Note that full integration under the comprehensive income tax implies that corporate profits should be taxed as they accrue. The CT could then be abolished. If retained, it would function as a withholding tax for the PT as well as a schedular income tax on the equity income of nonresidents. Full integration has been proposed by the Carter Commission (1966) and the US Department of the Treasury (1979), but it has never left the drawing board. Its practicality is in doubt.

${ }^{120}$ More than full relief is possible under the CTs in Member States (Portugal, Spain, the UK) that permit the payment of dividends out of exempt profits without imposing a compensatory tax at the corporate level. Whether or not preferences at corporate level should be passed through to shareholders is a difficult policy issue that is not discussed here (but see McLure (1979, ch. 4)).

${ }^{121}$ This regressive effect can be mitigated (as is done in Austria and Belgium) but not eliminated, by permitting low-income-bracket PT-payers, whose marginal ordinary PT rate is lower than the special PT rate, to opt for classical double taxation of their dividend income (with credit for the special PT imposed at source). Again, more than full relief can be provided under the special PT rate schemes if dividends are paid out of exempt profits.
} 


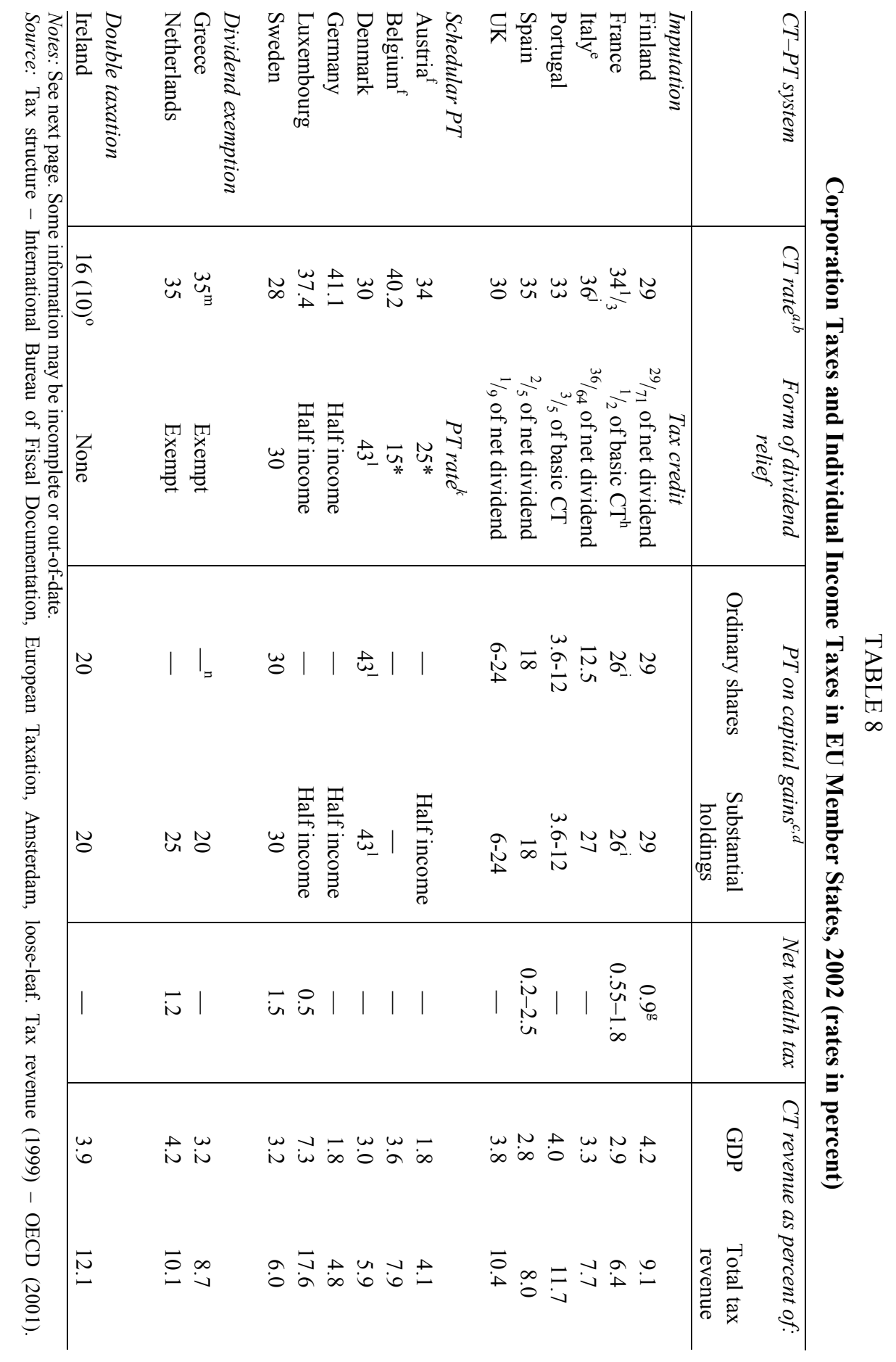


Notes to Table 8:

${ }^{\mathrm{a}} \mathrm{CT}$ rates include the following:

- surcharges in Belgium (3\%), France (3\%), Germany (5.5\%), Luxembourg (4\%), Portugal (10\%) and Spain $(0.75 \%-0.01 \%)$; and

- local taxes (deductible from corporate profits) in Germany (18\% ) and Luxembourg (10\%). Spain levies a local tax based on the type of business activity and the surface area of the premises.

${ }^{b}$ Flat minimum taxes, creditable against the final CT, are levied in Austria, France and Luxembourg (in the form of a net wealth tax). Lower or graduated CT rates apply to lower amounts of profits or to small businesses in Belgium, France, Ireland, Luxembourg, the Netherlands, Portugal, Spain and the UK.

${ }^{c}$ Usually, capital gains realized by companies are subject to CT at the normal rate; generally, the gains can be rolled over.

${ }^{\mathrm{d} C a p i t a l}$ gains are adjusted for inflation in Ireland and Luxembourg. Alternatively, short-term and long-term gains are taxed at different (effective) rates in Denmark, Portugal, Spain and the UK. PT rates shown are for long-term capital gains. Various Member States exempt small amounts of capital gains. Italy levies the tax on accrued gains.

${ }^{\mathrm{e}}$ Italy levies a regional tax on productive activities (IRAP), in fact an income-type VAT at $4.25 \%$.

${ }^{\mathrm{f}}$ Austria and Belgium permit a limited deduction from individual income of expenditures on the purchase of newly issued shares.

${ }^{g}$ In addition, nonresident companies and domestic legal entities other than corporations are subject to a $1 \%$ net wealth tax.

${ }^{h}$ France provides a $25 \%$ tax credit for the subscription to shares in specified companies.

${ }^{\mathrm{i}}$ French PT on capital gains of $16 \%$ plus full social taxes.

${ }^{\mathrm{j}}$ Italy levies a reduced rate of $19 \%$ on profits attributable to increases in equity capital (retained profits and newly issued shares).

${ }^{\mathrm{k}}$ An asterisk $(*)$ indicates that the special PT rate is a final withholding tax on option.

${ }^{1}$ In Denmark, share income not exceeding DKr 39,700 is taxed at $28 \%$.

${ }^{\mathrm{m}}$ The CT rate is $37.5 \%$ for Greek companies with bearer shares not quoted on the Athens Stock Exchange and on nonresident companies.

${ }^{n}$ In Greece, shares in unquoted corporations are taxed at $5 \%$ of the sale price.

${ }^{\circ}$ The rate given in parentheses applies to profits of qualifying manufacturing and processing companies.

ignored). Consequently, the choice between profit retention and distribution is not affected.

The recent trend in the EU has been to abolish imputation systems in favor of schedular taxes on dividend distributions as well as other capital income. The cross-border implications of imputation are found to be discriminatory and complicated. Germany and Ireland have substituted imputation by separate taxation of corporate profits and distributions, schedular or full. The UK has greatly reduced the tax credit and confined it to domestic shareholders. From 2001, the Netherlands simply exempts dividend income in the hands of shareholders (although it increased the net wealth tax rate on shares and other assets).

The tax treatment of realized capital gains, ${ }^{122}$ also shown in Table 8 , determines the $\mathrm{CT}+\mathrm{PT}$ on retained profits. Generally, a distinction is made between capital gains on ordinary (widely-held) shares and capital gains on substantial holdings, i.e. controlling interests in (closely-held) corporations. (Capital gains on substantial holdings often represent labor income sheltered in

${ }^{122}$ Exceptionally, Italy levies the tax on accrued gains in the case of ordinary shares. 
the corporate form at a CT rate that is lower than the marginal PT rate.) Table 8 indicates that six Member States do not tax capital gains on ordinary shares, but that all Member States bar Belgium tax capital gains on substantial holdings. The rates shown in the table are nominal rates. Deferral and numerous tax base preferences result in low effective capital gains tax rates.

The last two columns of Table 8 show that, in 1999, the CTs in the Member States accounted for, on average, 8.7 percent of total tax revenue or 3.5 percent of GDP. By comparison, the CT share for the US is 9.5 percent and the CT ratio 3.2 percent (OECD, 2001). Leaving Luxembourg out of consideration, ${ }^{123}$ the CT ratios of the Member States range from 1.8 percent in Germany, where only some 15 percent of all firms conduct their business in corporate form, to 4.2 percent in the Netherlands, where most businesses use the corporate form and which derives substantial CT revenue from natural gas. A comparison with earlier revenue figures indicates that tax competition - the 'race to the bottom' is not (yet) a serious issue. Although statutory tax rates have been lowered in the past 20 years, ${ }^{124}$ generally CT-revenue/GDP ratios have broadly stayed the same due to various tax base-broadening measures (Gorter and de Mooij, 2001). However, this does not account for the effects of rising profits (see Table 3) and the decline in the noncorporate form of doing business.

\section{(b) Treatment of Equity and Debt Income $e^{125}$}

Clearly, nominal tax rates on retained and distributed profits (the return on equity) diverge widely within and between Member States. Table 9 lists these rates along with the tax rate on interest (the return on debt). ${ }^{126}$ In addition, the top PT rate on other income is shown and the withholding taxes on dividend and interest remittances to nonresidents in other Member States.

\section{Discrimination of Profit Distributions}

Finland, Greece and the Netherlands are the only Member States that tax profit distributions and retentions at the same marginal CT/PT rates. As Table 9

\footnotetext{
${ }^{123}$ The high CT yields in Luxembourg are attributable to its favorable treatment of holding companies which have chosen the state for their headquarters.

${ }^{124}$ For a comparison of the decreases in CT (and top PT) rates, see Cnossen (1984, 1993 and 1997).

${ }^{125}$ This subsection draws heavily on Cnossen and Bovenberg (1997).

${ }^{126}$ Furthermore, taxes on net wealth and immovable property should be taken into account, but generally their yields are small. For a theoretical analysis of the impact of the taxes on the three forms of capital income in a dynamic general equilibrium framework, see Sinn (1985).
} 
TABLE 9

\section{Corporation Taxes and Individual Income Taxes on Capital Income} in EU Member States, 2002

\begin{tabular}{|c|c|c|c|c|c|c|}
\hline \multirow[t]{2}{*}{$\overline{C T-P T}$ system } & \multirow{2}{*}{$\begin{array}{c}\text { CT on } \\
\text { retained } \\
\text { profits }^{a}\end{array}$} & \multirow{2}{*}{$\begin{array}{c}\text { CT+ top- } \\
\text { PTon } \\
\text { distributed }^{\text {profits }}{ }^{b, c}\end{array}$} & \multirow[t]{2}{*}{$\begin{array}{c}\text { PT on } \\
\text { interest }^{d}\end{array}$} & \multirow{2}{*}{$\begin{array}{l}\text { Top PT } \\
\text { rate on } \\
\text { other } \\
\text { income }^{e}\end{array}$} & \multicolumn{2}{|c|}{$\begin{array}{c}\text { Withholding taxes on } \\
\text { nonresidents }\end{array}$} \\
\hline & & & & & Dividends & Interest \\
\hline \multicolumn{7}{|l|}{ Imputation } \\
\hline Finland & 29 & 29 & $29 * *$ & 52.5 & $0-15$ & 0 \\
\hline France & $34^{1 / 3}$ & 65.2 & $26 * * \mathrm{f}$ & 57.4 & $0-15$ & $0-15$ \\
\hline Italy & 36 & 44 & $27 * *$ & 45.6 & 15 & $0-15$ \\
\hline Portugal & 33 & 49 & $20 * *$ & 40 & $10-15$ & $10-15$ \\
\hline Spain & 35 & 52.7 & $48 *$ & 48 & 15 & $0-15$ \\
\hline UK & 30 & 53.3 & $40 *$ & 40 & 0 & $0-15$ \\
\hline \multicolumn{7}{|l|}{ Schedular PT } \\
\hline Austria & 34 & 50.5 & $25 * *$ & 50 & $0-15$ & 0 \\
\hline Belgium & 40.2 & 49.1 & $15^{* *}$ & 60.6 & 15 & $10-15$ \\
\hline Denmark & 30 & 60.1 & 47.6 & 47.6 & 15 & 0 \\
\hline Germany & 41.1 & 56.2 & $36.9 * *$ & 51.2 & 15 & 0 \\
\hline Luxembourg & 37.4 & 50.9 & 43 & 43 & 15 & $0-10$ \\
\hline Sweden & 28 & 49.6 & 30 & 56 & $0-15$ & 0 \\
\hline \multicolumn{7}{|c|}{ Dividend exemption } \\
\hline Greece & 35 & 35 & $10 * *$ & 42.5 & 0 & $0-10$ \\
\hline Netherlands & 35 & 35 & None & 52 & 15 & 0 \\
\hline \multicolumn{7}{|l|}{ Double taxation } \\
\hline Ireland & $16(10)$ & $51.3(47.8)$ & $20 * *$ & 42 & 0 & $0-15$ \\
\hline
\end{tabular}

${ }^{\mathrm{a}}$ See Table 8. Rates do not include capital gains taxes, if levied. Some information may be incomplete or outof-date.

${ }^{\mathrm{b}}$ Calculated as CT $+[(1-\mathrm{CT}) \mathrm{PT}]$ minus any tax credit if available.

${ }^{c}$ Withholding taxes on dividends paid to residents are imposed in Austria (25\%), Belgium (15\%), Denmark (28\%), Germany (21.1\%), Luxembourg (25\%), Italy (12.5\%), the Netherlands (25\%), Portugal (20\%), Spain $(18 \%)$ and Sweden $(30 \%)$. Taxpayers can choose whether or not to consider the withholding tax as final in Austria, Belgium, Denmark and Italy.

${ }^{\mathrm{d}}$ An asterisk (*) means that interest payments are subject to a withholding tax; a double asterisk (**) means that the withholding tax is final on option. Generally, royalty payments to residents are not subject to withholding tax, except in France (26\% - final), Spain (18\%) and the UK $(22 \%)$.

${ }^{\mathrm{e}} \mathrm{PT}$ rates include the following:

- surcharges in Belgium (3\%), Germany (5.5\%) and Luxembourg (2.5\%);

- surtaxes in France (CSG - 7.5\%; CRDS - 0.5\%; prélevement social - 2\%); and

- local taxes in Belgium (7.25\%), Denmark (32.6\%), Finland (16.5\%), Italy (1.4\% - surcharge) and Sweden $(31 \%)$.

fIncluding social taxes.

Source: Computed from International Bureau of Fiscal Documentation, European Taxation, Amsterdam, looseleaf. 
indicates, in all other Member States, the CT+PT on current distributions ${ }^{127}$ appears to be higher than the CT (plus capital gains tax, if any) on retained profits. ${ }^{128}$ The distortionary effects of this tax bias against profit distributions depends on the marginal source of finance (i.e. either retained profits or new equity). If firms finance their marginal investments through profit retention rather than new shares, they have to reduce dividends that would otherwise be available for distribution. Accordingly, the role of dividends is crucial. In this connection, the literature has developed two hypotheses, which are known as the 'traditional view' and the 'new view.' ${ }^{129}$

The traditional view argues that dividends offer nonfiscal benefits. Dividends provide a signal to shareholders, for instance, that all is well with the corporation, or they may limit financial discretion and hence potential misuse of funds by management. At the margin, corporations equalize the tax disadvantages and nontax advantages of profits distributions. A new investment will in part be financed by issuing new shares, therefore, because dividends cannot be lowered without cost. This implies that the higher (total) tax on dividend income compared with retained profits discourages new investment and distorts the dividend-payout decision.

The new view denies the existence of nontax advantages associated with profit distributions. Accordingly, the higher tax on dividend income should cause corporations to prefer profit retentions over new share issues as the marginal source of finance. Profit retention enables shareholders to enjoy the return on the new investment in the form of tax-preferred capital gains. Moreover, they save on the PT on dividend income that they would have to pay if profits had been distributed rather than retained. The capitalized value of this tax saving is exactly equal to the discounted value of the tax on distributed profits that must be paid in the future. Therefore, the tax on dividends does not distort investment decisions - at least if the corporation generates sufficient profits to finance marginal investments through retained profits, and the tax rate on dividends is expected to remain constant in the future.

The policy implications of the two views are quite different, as Head (1996) points out. Under the new view, in contrast to the traditional view, any CT reform aimed at greater integration with the PT is of doubtful relevance from an

\footnotetext{
${ }^{127}$ Note that the following simplifying assumptions have been made in calculating the effective CT+PT rates on distributed profits: (a) CTs are borne by profits; (b) after-CT profits are fully distributed; (c) dividends are received by resident PT-liable individuals; (d) individuals and corporations face the maximum CT and PT rates, inclusive of taxes levied by subordinate levels of government; (e) CT and PT rates remain unchanged; and (f) the amount of pre-tax corporate profits available for distribution remains the same, regardless of the level of the tax rates or the degree of mitigation. See OECD (1991).

${ }^{128}$ The CT + PT rate on distributed profits is also clearly higher than the top PT rate on other income in Germany, Luxembourg, Portugal, Spain and the UK.

${ }^{129}$ For reviews and analyses of the two views on dividend taxation, see Poterba and Summers (1985), Sinn (1985 and 1991), Zodrow (1991) and Sørensen (1994a and 1995).
} 
efficiency point of view, but must clearly be rejected on equity grounds because it results in windfall gains to existing shareholders. Most empirical studies support the traditional view. ${ }^{130}$ Whatever view is adopted, taxing dividends twice always harms investment by new businesses, which have to rely on new share issues to provide for their equity needs. The discrimination of new equity under less than full imputation systems, therefore, contributes to the concentration of market power by discouraging the entry of new firms. It is especially detrimental to small, growing firms that provide an important impetus to technological innovation.

\section{Preferential Treatment of Debt}

The combined PT/CT on debt equals the PT-rate on interest income, while the combined burden on retained earnings is the sum of the CT-rate and the capital gains tax rate. Table 9 indicates that interest appears to be taxed at lower rates than the CT+PT on profit distributions. This is obviously the case in seven Member States which tax interest at a lower nominal rate than retained profits. In the other Member States, the favorable treatment of interest is somewhat difficult to gauge, because the effective tax rate on capital gains is not known. ${ }^{131}$

However, the growing liberalization of capital markets implies that the tax system increasingly favors debt over retentions, because it increases opportunities for avoiding the PT on interest. Continued financial innovation makes debt and equity increasingly close substitutes. In particular, the taxexempt status of institutional investors, such as pension funds, facilitates the preferential treatment of the return on debt. Typically, interest income accruing to pension funds is not taxed (neither is dividend income, but such income is taxed at source under the CT) ${ }^{132}$ Indeed, capital income may possibly be subsidized if lightly taxed assets are financed with loans, the interest of which is deductible against the taxable income of the payer but not taxed at the level of the payee.

The tax-favored status of debt also discriminates against corporations that face difficulties in attracting debt, because they do not yet enjoy a high credit rating, own mainly nonliquid assets (such as firm-specific machinery), against which it is difficult to borrow, or generate insufficient taxable profits to be able to deduct interest. Consequently, these corporations, which tend to be fledgling

\footnotetext{
${ }^{130} \mathrm{An}$ important implication of the new view is that the market value of corporate assets exceeds existing share values. This does not seem to be the case.

${ }^{131}$ The new Dutch tax exacerbates the debt-equity distinction since debt income is taxed once but equity income twice (this double tax was previously mitigated by not taxing capital gains at individual shareholder level) (Bovenberg and ter Rele, 1998).

${ }^{132}$ In addition, the tax-exempt status of institutional investors affects their portfolio choice and thereby the ownership structure of firms. In particular, institutional investors tend to prefer bonds over shares, as the prices of shares, which yield a large part of their return in the form of untaxed capital gains, are bid up by taxable investors.
} 
enterprises, have to incur higher capital costs on account of taxation than older, established corporations with either easier access to debt financing or sufficient retained profits to finance new investments. In short, the equality of competitive conditions is violated.

\section{Cross-Border Effects}

The in-state distortions described above yield important EU-wide implications for the taxation of equity and debt income. As regards equity income, the higher tax on dividends, which stimulates profit retention, reduces the amount of capital becoming available on European capital markets and thus hampers the development of European share markets. Furthermore, investments by old firms financed through retained earnings tend to yield a lower (before-tax) return. Beyond that, the tax bias in favor of old firms inhibits the entry of new firms. Accordingly, the tax system infringes on competitive conditions, thereby jeopardizing the dynamics of the internal market. Moreover, taxing profit distributions twice discriminates in favor of Member States with many mature firms (which do not need new equity). Furthermore, it confers an artificial advantage on Member States with corporations that conform to the 'conduit' model of the firm (with shareholders managing the company) and, therefore, do not need to distribute a large portion of their profits to satisfy shareholders.

As regards debt income, the ongoing internationalization and liberalization of capital markets suggests that interest is hardly taxed, because these developments increase opportunities for evading or avoiding the PT or CT on interest income. Whereas retained earnings are taxed at source through the CT, the tax authorities cannot be sure that cross-border interest payments are reported and taxed. ${ }^{133}$ Moreover, withholding rates on cross-border interest payments (which vary by class of payer and payee, and by type of financial instrument - by itself a source of wasteful tax arbitrage) are very low (Table 9). ${ }^{134}$ The result, as Huizinga (1994) concludes, is that international interest income to a large extent escapes taxation. This favors international debt finance, skews investors' portfolios and results in an arbitrary division of the interest tax base between lending and borrowing Member States. ${ }^{135}$

\footnotetext{
${ }^{133}$ Early on, Bird and McLure (1990) drew attention to the erosion of the capital income base through the combination of interest deductibility, financial innovation, international tax arbitrage and evasion. For a general treatment, see also Owens (1993). The European Commission (1996) has also expressed its concern with the situation.

${ }^{134}$ In spite of various early efforts (European Commission, 1989a) to stem the tide, the general level of interest withholding taxes has declined in the past two decades.

${ }^{135}$ Furthermore, at the EU level, the preferential treatment of debt favors Member States with institutions (banks and large firms with liquid assets) that allow substantial debt finance. German banks, for example, often resemble holding companies that are closely involved in the activities of German businesses. In this situation, the high CT rate does not discourage domestic investment, but mainly acts as a protective device against
} 


\section{Conclusions}

The most important conclusions of this brief review are the following.

First, dividend and interest received by in-state share- and debtholders is increasingly being taxed at schedular PT rates in the form of final withholding taxes. Apparently, the taxation of capital income jointly with labor income on the basis of ability-to-pay is not viewed as important as it used to be.

Secondly, in nearly every Member State, effective $\mathrm{CT}+\mathrm{PT}$ rates on investment returns vary depending on the choice of financing (equity or debt), the corporation's dividend policy (distribution or retention), the maturity of the corporation (new or old), the form in which the investment is undertaken (the corporate form or the noncorporate form), the tax status of the recipient of the return (liable to PT and/or CT, or exempt) and the place of residence of the recipient of the return (at home or abroad). Broadly, debt finance is favored and individual investors are discriminated against (also, see OECD, 1991).

Thirdly, the symbiosis between interest deductibility and capital-rich taxexempt domestic and foreign sectors (and other opportunities for tax arbitrage) erodes the corporate (and capital) income tax base. This effect is reinforced by the substitution of hard-to-reach international debt (interest being taxed on the residence principle) for easier-to-tax equity (profits being taxed on the source principle). ${ }^{36}$

\section{(c) Effective Tax Rates}

The analysis in the previous paragraphs is corroborated by micro forwardlooking studies which calculate average and marginal effective tax rates with respect to different sources of finance, assets and recipients of investment income. Based on the methodology pioneered by King and Fullerton (1984), these studies draw on the statutory features of the tax system to compute implicit tax rates for hypothetical investment projects (in other words, new capital), given the rate of inflation and industry-specific financing and investment patterns. The advantage of micro forward-looking studies is that they provide an indication of the potential incentive effects of the $\mathrm{CT}$ system and enable a comparison between CT systems in different Member States. By contrast, micro backwardlooking studies measure effective average tax rates on old capital by expressing

\footnotetext{
foreign takeovers and foreign ownership of domestic firms, because foreigners do not have the same easy access to bank finance.

${ }^{136}$ This implies that the $\mathrm{CT}$ is importantly a tax on rents and returns to risk-bearing (business cash flow), not a tax on the normal return to capital (see Section II). It is surprising that this view, first voiced by Stiglitz (1976), has so little influence on policy-makers. If it had more, explicit cash-flow taxation and, by extension, individual consumption taxes (in fact, the regime for most labor income) might be higher on the political agenda. Apparently, the body politic does want to tax the normal return to capital. This treatise proceeds on that premiss.
} 
CT collections or liabilities as a percentage of actual corporate profits shown in financial statements. ${ }^{137}$

TABLE 10

EU Member States: Effective Average Corporation Tax Rates (EATRs) ${ }^{\mathrm{a}}$

\begin{tabular}{|c|c|c|c|c|c|}
\hline & \multirow{2}{*}{$\begin{array}{c}\text { Statutory } \\
\text { tax }^{b} \\
\text { rates }^{b} \\
2002\end{array}$} & \multicolumn{3}{|c|}{ Micro forward EATRs, 2001} & \multirow{2}{*}{$\begin{array}{c}\text { Micro backward } \\
\text { EATRs, }{ }^{c} 1999\end{array}$} \\
\hline & & Overall & $\begin{array}{l}\text { Retained } \\
\text { earnings }\end{array}$ & Debt & \\
\hline Germany & 41.1 & 34.9 & 38.7 & 27.7 & 21.8 \\
\hline Belgium & 40.2 & 34.5 & 39.1 & 25.8 & 13.6 \\
\hline Luxembourg & 37.4 & 32.2 & 36.6 & 24.0 &.. \\
\hline Italy & 36 & 27.6 & 28.7 & 25.5 & 26.4 \\
\hline Netherlands & 35 & 31.0 & 35.2 & 23.3 & 17.9 \\
\hline Spain & 35 & 31.0 & 35.2 & 23.3 & 16.2 \\
\hline Greece & 35 & 28.0 & 32.4 & 19.7 &.. \\
\hline France & $34 \frac{1}{3}$ & 34.7 & 39.0 & 26.8 & 17.6 \\
\hline Austria & 34 & 27.9 & 30.7 & 22.6 & 13.5 \\
\hline Portugal & 33 & 30.7 & 34.8 & 23.0 & 15.5 \\
\hline UK & 30 & 28.3 & 31.8 & 21.7 &.. \\
\hline Denmark & 30 & 27.3 & 30.7 & 21.0 & 20.9 \\
\hline Finland & 29 & 26.6 & 30.0 & 20.2 & 20.9 \\
\hline Sweden & 28 & 22.9 & 26.0 & 17.1 & 13.0 \\
\hline Ireland & $16(10)$ & 10.5 & 11.7 & 8.2 & .. \\
\hline \multicolumn{6}{|l|}{ European Union } \\
\hline Mean & 32.9 & 28.5 & 32.0 & 22.0 & 17.9 \\
\hline Standard deviation & 6.0 & 6.0 & 6.9 & 4.7 & 4.2 \\
\hline Pearson coefficient & & 0.92 & 0.91 & 0.93 & 0.12 \\
\hline
\end{tabular}

${ }^{\mathrm{a}}$ All effective tax rates pertain to CTs only. PTs on dividends, interest, royalites and other capital income have not been taken into account.

${ }^{\mathrm{b}}$ Ranked in order of highest statutory rate.

${ }^{\mathrm{c} C a l c u l a t e d}$ on actual corporate profits inclusive of depreciation.

Sources: Statutory tax rates - Table 5; effective tax rates (Sweden, 1998) - Nicodème (2001); EATRs Devereux and Griffith (2001).

The results of an important micro forward-looking study by Devereux and Griffith $(1998,2001)$ for the European Commission are shown in Table 10. Broadly, the ranking of the overall effective average tax rates, calculated at a

\footnotetext{
${ }^{137}$ Similarly, macro backward-looking studies - e.g. Mendoza, Razin and Tesar (1994) - relate CT revenues to the net or gross operating surplus of corporations shown in national accounts. Nicodème (2001) rightly emphasizes that micro forward- and micro (or macro) backward-looking studies are not measuring the same thing. Hence, their results are difficult to compare.
} 
given post-tax rate of return, ${ }^{138}$ is in line with the statutory tax rates (the Spearman ranking coefficient is 0.78). Although high tax rates tend to be correlated to narrow tax bases, generally tax rate differentials outweigh the differences in tax bases (European Commission, 2001). Among Member States, Germany, France and Belgium have the highest effective tax rates, while Finland, Sweden and Ireland tend to be in the lower range of the ranking. As regards sources of finance, the effective tax rate on retained profits is, on average, 10 percentage points higher than the effective tax rate on interest. ${ }^{139}$ Since the rates do not reflect behavioral responses, it is not known to what extent the potential distortions affect real investment (and saving) decisions (Fullerton, 1986). A shortcoming is also that country-specific tax enforcement features are not captured.

Micro backward-looking studies, based on data of corporate profits culled from financial statements, do not have these shortcomings. A recent study by Nicodème (2001) uses these data to calculate the effective tax rates of the manufacturing sector for 11 EU Member States. ${ }^{140}$ As shown in Table 10, Sweden has the lowest effective corporate tax rate (13 percent -15 percentage points lower than the statutory tax rate of 28 percent) and Italy the highest (26.4 percent - some 10 percentage points lower than the statutory tax rate). It should be noted, however, that the rates have been calculated on corporate profits including depreciation, which eliminates intercountry differences in depreciation schedules. Nicodème concludes that there are large differences between statutory and effective tax rates within as well as between Member States for different sectors and sizes of companies. ${ }^{141}$ As the Pearsons (correlation) coefficient of 0.12 indicates, there is hardly any correspondence between the statutory tax rates and the effective tax rates of Nicodème's study. Apparently, this cannot be attributed to differences in tax bases (European Commission, 2001). Accordingly, it suggests that the ability to use tax-planning techniques (transfer

\footnotetext{
${ }^{138}$ This post-tax rate of return includes infra-marginal profits. In contrast, under marginal effective tax rates, the post-tax rate of return just equals the alternative market interest rate. Other studies, e.g. Baker and McKenzie (2001), compute the effective tax rates at a given pre-tax rate of return.

${ }^{139}$ In addition, Devereux and Griffith (2001) calculate effective tax rates on various types of assets. It appears that the tax systems of the Member States tend to favor investments in intangibles and machinery over buildings and inventories. The spread between the effective tax rates on these assets, however, is not as great as the spread between retained earnings and debt.

${ }^{140}$ This study draws on the methodology developed by Buijink, Jansen and Schols (1999). Nicodème (2001) makes a useful comparison of the pros and cons of the various approaches to computing effective corporate tax rates. See also OECD (2000a).

${ }^{141}$ Within Member States, 'energy and water' and 'transport and communications' appear to be favored, while 'trade' is taxed more highly. Furthermore, small companies appear to be favored in Austria, Portugal and Denmark, while the opposite is true for small companies in Sweden, Finland, Belgium and France.
} 
pricing, thin capitalization) to reduce tax liabilities differs between Member States.

Differences in effective tax rates between Member States should induce a relocation of real activities across the EU. ${ }^{143}$ A recent study by Gorter and Parikh (2000) confirms this. The authors find a (high) semi-elasticity of out-of-state investment within the EU of, on average, -4.3. This means that for every 1 percentage point reduction in a Member State's effective CT, investors from other Member States will, on average, increase their investment by 4.3 percent in that state. A comparison of this study with work on US foreign direct investment in the EU suggests that intra-EU investments are more sensitive to taxes than EU-wide inbound or outbound investments are. This testifies to the increasing capital mobility within the EU and accordingly the increased sensitivity of investments to interstate tax differentials.

\section{European Commission Proposals (Bolkestein Report)}

\section{(a) Summary}

The differences in the effective levels of taxation between the Member States (computed on the basis of the Devereux/Griffith model) are one of the three central themes in a recent report issued by the European Commission (2001). Three-quarters of these differences, according to the Commission, can be attributed to differences in statutory tax rates. ${ }^{144}$ The differences would imply that investment decisions in the EU are driven, to an important extent, by tax considerations instead of gross (social) returns. Also, one finding is that inbound and outbound investments are taxed more heavily than identical domestic investment projects, although EU-wide corporations tend to be taxed less heavily than otherwise identical in-state businesses (including tax-favored small and medium-sized firms).

Secondly, the Commission identifies the main provisions that hamper crossborder economic activity and impede the creation of pan-European business structures. Primarily, these provisions have regard to the requirement that corporate profits have to be calculated (often arbitrarily) on an arm's-length basis (separate accounting). This may involve double taxation if the arm's-length price in one Member State is not accepted by the tax authorities in another Member State. Perhaps most importantly, separate accounting means that tax losses in one Member State cannot be offset against taxable profits of affiliated

\footnotetext{
${ }^{142}$ There are few empirical studies on the extent of transfer pricing manipulation and thin capitalization in the EU, but see Bartelsman and Beetsma (2000) on transfer pricing. On the other hand, there is a wealth of empirical studies for the US (Hines, 1999), nearly all of which indicate that the phenomenon is important.

${ }^{143}$ For a useful review of various empirical studies, also with respect to the US, see Gorter and de Mooij (2001).

${ }^{144}$ As indicated by Table 10 , there is a close correlation between the ranking of statutory and effective average tax rates.
} 
corporations in other Member States. ${ }^{145}$ Furthermore, separate accounting implies the taxation of capital gains on assets transferred to other Member States. This means that the tax costs of cross-border mergers, acquisitions and internal reorganizations can be high. This jeopardizes the functioning of the internal market.

Thirdly, the Commission calls attention to the high costs that businesses with EU-wide operations have to incur in complying with possibly 15 different CT regimes and to the high administrative costs that governments face in having to monitor the compliance.

The Commission explores two approaches that it believes would mitigate the distortions, facilitate cross-border economic activity and reduce the high compliance and administrative costs. First, it proposes a wide range of targeted measures, such as an extension of the coverage of the parent-subsidiary directive, the merger directive and the arbitration convention, as well as the adoption of the interest/royalty directive and the directive on loss compensation. Furthermore, Member States could be encouraged to expand the programs for bilateral or multilateral Advance Pricing Agreements (in lieu of the ex-post determination of transfer prices) and improve the network of double taxation conventions (or perhaps negotiate a multilateral treaty conferring interpretive jurisdiction on the European Court of Justice).

Secondly, the Commission examines a number of general remedial measures that remove obstacles to cross-border investment and consolidation of businesses by establishing a common tax base for EU activities. The main proposals in this field are Common Base Taxation (CBT) and Home State Taxation (HST) ${ }^{146}$ Under CBT, two or more Member States would harmonize their rules for computing taxable profits in respect of firms with cross-border operations (national rules would be maintained for firms with purely domestic operations). Under HST, participating Member States would maintain their own profit determination rules, but businesses with cross-border operations would be taxed in the Member State in which their headquarters are located (exemplifying the principle of mutual recognition). ${ }^{147}$

Under CBT as well as HST, taxable profits would be determined on the basis of consolidated accounts. Separate accounting by reference to arm's-length pricing rules would become redundant for the participating Member States (not

\footnotetext{
${ }^{145}$ Offset is possible for losses of permanent establishments whose operations are consolidated with those of the parent.

${ }^{146}$ Other rather far-reaching proposals are a European CT (operating alongside national rules, revenues to be paid into the EU budget) and an EU-wide CT base replacing national tax bases (but to be allocated to Member States, which could apply their own rates). The unanimity rule, however, would make the adoption of these proposals unlikely. Accordingly, the Commission pays less attention to these options. For a useful summary and evaluation, see Weiner (2002).

${ }^{147}$ Thus, HST resembles the Commission's proposal for a definitive VAT regime (European Commission, 1996a).
} 
other Member States or third countries). Consolidated profits would be shared by the participating Member States on the basis of the weighted share in various economic activities of the corporation, represented by such factors as its sales, payroll and property (formula apportionment). ${ }^{148}$ Subsequently, Member States would apply their own tax rates.

\section{(b) Evaluation ${ }^{149}$}

No doubt, the European Commission's report is an impressive inventory of options to remove obstacles to cross-border economic activity. Unfortunately, however, the Commission does not analyze the sensitivity of investments to taxinduced differences in returns. ${ }^{150}$ Hence, it cannot provide an indication of the size of the tax-induced distortions in the internal market and thus the urgency of tax coordination. While various targeted remedial measures (e.g. on loss compensation) deserve to be implemented without delay (provided adequate safeguards against abuse can be found), the comprehensive measures require further discussion.

Although CBT and HST would probably contribute to a reduction of crossborder obstacles, they would also increase tax competition. Under both proposals, Member States will have an incentive to use rate setting more intensively, because the tax base cannot be used anymore to attract real investment. Tax competition would also increase on account of the greater transparency of the tax base, which cannot mask differences in effective tax rates anymore. Furthermore, HST would increase tax competition for headquarter locations, because Member States would be induced to narrow their tax bases. As a result, new externalities would arise, because individual Member States would not take into account the effect of a smaller tax base on the tax revenues of other Member States. ${ }^{151}$

A second problem is that the proposals do not address the distortions of the various CTs within Member States on financing structures (equity vs. debt) and various types of investment (buildings, machinery, inventories, intangibles). The report notes that the variations in effective tax rates are significant and that they are much greater if PTs are taken into account. Distortions within Member States cause distortions between Member States (a point that the Commission chooses to ignore). Hence, the removal of formal cross-border obstacles to economic activity is insufficient to level the CT playing field. Indeed, as the VAT

\footnotetext{
${ }^{148}$ Tax base sharing on the basis of formula apportionment is widely practiced by US states and Canadian provinces.

${ }^{149}$ This subsection draws on Bovenberg, Cnossen and de Mooij (2002).

${ }^{150}$ For an analysis of the sensitivity of foreign investments to tax differentials, see de Mooij and Ederveen (2001).

${ }^{151}$ Simulations by the Commission show that HST would increase the variation in effective tax rates by more than 30 percent. By contrast, simulations of CBT show almost no effect on the variation in effective tax rates.
} 
experience indicates, the elimination of in-state distortions is a prerequisite to the elimination of interstate distortions. ${ }^{152}$

HST would even exacerbate the distortions within Member States, because corporations owned by shareholders from different Member States but doing business within the same Member State face different CT regimes. This jeopardizes the competitive playing field between different EU firms and between small nationally operating businesses and multinationals. Apart from hampering the functioning of the internal market, it would also undermine the legitimacy of the Member State's own tax system. In addition, HST and CBT might increase the distortions attributable to differences in effective tax rates, because Member States with relatively high nominal tax rates tend to have relatively narrow tax bases.

Thirdly, the coexistence of two different CT systems - national and European - should invite tax arbitrage. Different business firms could cooperate, for instance, to compensate each other's losses or to make use of more favorable tax rules in another Member State (under HST) or the EU regime (under CBT). Also, cross-border takeovers and mergers would become more attractive. Hence, ownership patterns would tend to be determined by tax considerations instead of economic costs and benefits. The tax-induced concentration of market power would jeopardize the functioning of the internal market and increase the pressure on the EU's competition authorities.

A fourth problem under CBT and HST concerns formula apportionment. If tax base sharing is based on payroll, sales and property, then the CT becomes a tax on these factors. This creates new distortions in the allocation of resources within the EU. Firms would have an incentive to shift part of their payrolls or business assets to Member States with low statutory tax rates, and governments could manipulate the relative weights of payroll and property to stimulate employment and investment (Goolsbee and Maydew, 2000). Furthermore, if tax rates continued to differ within the EU so that profit shifting remained attractive, a system of formula apportionment would have to be supplemented by unitary combination rules under which legally separate but economically integrated corporations were treated as a single group for tax purposes (unitary taxation).

According to Mintz (2002) the proposals are fraught with problems, and a serious question arises as to whether HST or CBT is worth the effort. Most likely, rules will grow to limit opportunities for tax arbitrage. In some instances, corporations will have to deal with more than 15 tax systems. Loss compensation will be easier, but the dark side of the approach is that trading in losses will be encouraged. The treatment of foreign income earned by consolidated corporations will be a thorny issue, and transfer pricing and cost allocation

\footnotetext{
${ }^{152}$ In this context, the removal of cross-border obstacles can be compared with the removal of border controls under the pre-VAT turnover taxes. The abolition of these controls was rightly seen as a necessary, yet insufficient, condition for free trade and free competition in product markets.
} 
problems with third countries will continue to exist. Overall, Mintz believes that the options will result in minimal economic gains, if any at all.

Nevertheless, harmonization of the CTs within the EU appears attractive, because it would eliminate tax arbitrage, reduce obstacles to doing business on an EU-wide basis and eliminate tax-induced distortions of the intra-EU allocation of capital. A basic issue in this context is whether full harmonization should be achieved through tax competition or tax coordination. ${ }^{153}$ The introduction of HST, for instance, represents harmonization through tax rate and tax base competition. This would jeopardize the effective taxation of capital income in the EU. Perhaps, therefore, the search should be for measures that effectively tax capital income as well as eliminate distortions of capital income tax systems within Member States (as a prerequisite for an efficient allocation of capital between Member States). ${ }^{154}$ Accordingly, an alternative scenario for capital income tax coordination and harmonization is sketched below.

\section{A Pragmatic Alternative}

An alternative scenario for capital income tax coordination and harmonization would comprise five sequential steps: (a) the introduction of dual income taxes (DITs) under which all capital income would be taxed once at a single rate to mitigate the distorting effects of current differential-rate CT $+\mathrm{PT}$ systems on corporate financial and investment policies, (b) the introduction of interest withholding taxes throughout the EU (or, alternatively, the treatment of interest on a par with dividends) to effectively tax the normal return to capital and mitigate incentives for thin capitalization, and (c) the approximation of CT rates to eliminate incentives for transfer pricing manipulation (and thin capitalization). Following these steps, a fresh review should be made of (d) the introduction of EU-wide Common Base Taxation with formula apportionment and, subsequently, (e) the adoption of a European CT after the EU obtains the legitimacy and the power to tax.

\section{(a) Dual Income Tax (DIT) $)^{155}$}

The dual income tax (DIT) is a pragmatic approach to the uniform taxation of capital income within Member States. In the early 1990s, DITs were introduced in the Nordic countries, especially Norway, Finland and Sweden (Sørensen,

\footnotetext{
${ }^{153}$ Tax competition is often recommended to promote efficiency in the government sector, but for a skeptical view, see Sørensen (forthcoming).

${ }^{154}$ In addition, where appropriate, it would be important to remove various obstacles to cross-border economic activity through targeted measures, as indicated by the European Commission (2001).

${ }^{155}$ For a review and evaluation of the economic and technical aspects of the DIT on which this subsection draws, see Cnossen (1999b). For a study on the effects of the capital income tax in the Nordic countries on investment before the reform, see Dufwenberg, Koskenkylä and Södersten (1994).
} 
1994). ${ }^{156}$ Generally, the introduction of the DIT caused few

TABLE 11

Dual Income Taxes in Norway, Finland and Sweden, 2002

\begin{tabular}{|c|c|c|c|}
\hline & Norway & Finland & Sweden \\
\hline Year of introduction & 1992 & 1993 & 1991 \\
\hline Income tax rates $(\%)^{a}$ & & & \\
\hline Corporate profits & 28 & 29 & 28 \\
\hline Other capital income & 28 & 29 & 30 \\
\hline Labor income $^{\mathrm{b}}$ & $28-47.5$ & $30.5-52.5$ & $28-56$ \\
\hline $\begin{array}{l}\text { Costs of earning income } \\
\text { and basic allowances }\end{array}$ & $\begin{array}{l}\text { Deductible } \\
\text { at basic rate }\end{array}$ & $\begin{array}{l}\text { Deductible } \\
\text { at basic rate }\end{array}$ & $\begin{array}{l}\text { Deductible } \\
\text { at basic rate }\end{array}$ \\
\hline $\begin{array}{l}\text { Basic allowance } \\
\text { for capital income }\end{array}$ & Yes & No & No \\
\hline $\begin{array}{l}\text { Offset of capital income } \\
\text { against labor income }\end{array}$ & In first bracket & $\begin{array}{c}\text { Through tax credit } \\
\text { at basic rate }\end{array}$ & $\begin{array}{c}\text { Through tax credit } \\
\text { at basic rate }\end{array}$ \\
\hline $\begin{array}{l}\text { Method of } C T-P T \\
\text { integration }\end{array}$ & Full imputation & Full imputation & No integration \\
\hline \multicolumn{4}{|l|}{ Corporation tax rates $(\%)$} \\
\hline Distributed profits & 28 & 29 & $28+30 \% \mathrm{PT}$ \\
\hline Retained profits & $\begin{array}{l}28 \text { plus } \\
28 \% \text { PT on capital } \\
\text { gains minus net } \\
\text { retained profits }\end{array}$ & $\begin{array}{c}29 \text { plus } \\
28 \% \text { PT on } \\
\text { capital gains }\end{array}$ & $\begin{array}{c}28 \text { plus } \\
30 \% \text { PT on } \\
\text { capital gains }\end{array}$ \\
\hline \multicolumn{4}{|l|}{ Withholding taxes $(\%)^{c}$} \\
\hline Dividends & & & \\
\hline Portfolio & 15 & 15 & 15 \\
\hline Direct investment & $0 ; 10 ; 15$ & $0 ; 10 ; 15$ & $0 ; 10 ; 15$ \\
\hline Interest & - & - & - \\
\hline Royalties & - & 0 & - \\
\hline Net wealth tax rates (\%) & $0.9-1.1$ & 0.9 & 1.5 \\
\hline
\end{tabular}

${ }^{a}$ Including local taxes.

${ }^{b}$ Not including nondeductible social security contributions, which increase effective marginal tax rates.

${ }^{\mathrm{c}}$ Treaty countries.

Source: International Bureau of Fiscal Documentation, European Taxation, Amsterdam, loose-leaf.

${ }^{156}$ Over the years, Norway and Finland have adhered closely to the requirements of a pure DIT. In 1995, however, Sweden deviated from the original model, mainly by taxing corporate profit distributions and, along with Finland, retentions twice. 
economic, political or administrative problems. ${ }^{157}$ The Austrian and Belgian capital income tax systems also exhibit features of the DIT.

The main features of the Nordic dual income tax are shown in Table 11. These features can be summarized as follows.

\section{Separation of Capital and Labor Income}

All income is separated into either capital income or labor income, also called earned income or individual income. Capital income includes business profits (representing the return on equity), dividends, capital gains, interest, rents and rental values. Labor income consists of wages and salaries (including the value of labor services performed by the owner in his or her business), fringe benefits, pension income and social security benefits. Royalties are taxed as labor income or as capital income (if know-how is acquired or capitalized).

\section{Tax Rates}

Basically, all capital income is taxed at the proportional CT rate -28 percent in Norway and 29 percent in Finland (Sweden taxes individual capital income somewhat higher than corporate profits) - while labor income is subject to additional, progressive PT rates. To minimize tax arbitrage, the tax rate on labor income applicable to the first income bracket is set at (approximately) the same level as the proportional CT rate.

\section{Costs of Earning Income and Allowances}

All costs of earning income and all allowances are deductible only from income subject to the basic or proportional tax rate. This limitation means that the tax benefit of mixed costs (which incorporate an element of individual consumption) incurred in earning income does not rise with income. But the limitation discriminates against wage-earners, since the self-employed can deduct their business costs against the top marginal tax rate on labor income.

\footnotetext{
${ }^{157}$ In Sweden, however, the adoption of the DIT coincided with a deep recession (unrelated to the DIT per se). Agell, Englund and Södersten (1996) conclude that the limitation of interest deductibility for homeowners - the after-tax interest rate for an average employee increased from minus 7 percent in 1980 to plus 7 percent in 1991 - and especially the increase in value added tax on new housing and housing maintenance of at least 10 percentage points squeezed short-term effective demand, causing a decline in gross national product of 1 percentage point. As these authors point out, however, over time, the Swedish reform should improve the efficient allocation of resources (away from durable consumer goods towards investment goods) and strengthen the incentives to invest in human capital.
} 


\section{Offset of Capital Income against Labor Income}

Finland and Sweden tax capital and labor income entirely separately. Alternatively, in Norway, the two forms of income are taxed jointly at the CT rate, while net labor income is subsequently taxed at additional progressive PT rates. Joint taxation permits the offset of negative capital income against positive labor income. But the same effect is achieved in Finland and Sweden by permitting a tax credit for capital income losses (calculated at the basic rate) against the tax on labor income. Furthermore, joint taxation, as in Norway, permits the application of joint basic allowances. Separate taxation, on the other hand, enables the imposition of flat source taxes, if desired, on various forms of capital income, as is done in Finland. ${ }^{158}$

\section{Avoidance of Double Taxation}

In Finland and Norway, double taxation of distributed profits at the corporate level and the shareholder level is avoided through a full imputation system. ${ }^{159}$ Compensatory taxes guarantee that no dividends are paid out of exempt profits without having borne $\mathrm{CT}$, which would subsequently be creditable against the shareholder's PT. Alternatively but equivalently, double taxation can be avoided by exempting dividend income at the shareholder level, as Sweden used to do in 1994. ${ }^{160}$

Double taxation of retained profits at the corporate level in conjunction with the taxation of realized capital gains at the shareholder level is avoided in Norway by permitting shareholders to write up the basis of their shares by retained profits net of CT. The system is called the RISK method. ${ }^{161}$ Similarly, the basis is written down if losses occur or profits are distributed out of previously accumulated earnings. Appropriate adjustments are also made if capital is paid in or paid out. The first-in/first-out principle applies if part of the same shareholding is sold. The RISK method deals both with the danger of excessive distributions of retained profits and with the unwarranted exemption of

\footnotetext{
${ }^{158}$ Unfortunately, separate taxation also facilitated the introduction of diverging basic labor and capital income tax rates in Finland and Sweden after 1995.

${ }^{159}$ The equal treatment of retained and distributed profits was breached in Norway in 2000 when the imputation tax credit for dividends in excess of NOK 10,000 was reduced to 17 percent of the dividend income.

${ }^{160}$ In the elections, however, it transpired that voters could not appreciate the equivalency between exemption and imputation (both with a compensatory tax at the corporate level to prevent the payment of dividends from untaxed profits). Hence, Sweden reverted to the double tax on distributed profits. Also, exemption would have made it problematic to maintain withholding taxes on dividends paid out to foreign shareholders (as a proxy for the domestic capital gains tax, which cannot be levied), who might invoke the nondiscrimination clause included in most tax treaties. Finally, exemption made it more difficult to establish eligibility for income-tested transfer payments.

${ }^{161}$ RISK stands for Regulering av aksjenes Inngangsverdi med endring i Skattlagt Kapital: adjustment of basis by changes in capital subject to tax.
} 
realized gains at shareholder level due to unrealized gains at corporate level. ${ }^{162}$ The double tax on retained profits is mitigated in Finland (only 70 percent of capital gains are taxed), but fully maintained in Sweden.

\section{Withholding Taxes}

Single taxation of capital income can be ensured through withholding or source taxes at the corporate level or at the level of other entities paying interest, royalties or other capital income. In principle, withholding or source rates should be set at the level of the CT rate. Consequently, these rates could represent the final tax liability if capital income is taxed separately from labor income and no basic allowance applies. This is the case in Finland and Sweden with respect to interest income. However, no country imposes a withholding tax on interest or royalties paid to nonresidents in treaty countries. Withholding taxes are only imposed on dividends paid to nonresident (portfolio) shareholders. ${ }^{163}$

\section{Proprietorships and Closely-Held Corporations ${ }^{164}$}

In Finland and Norway, taxable profits of proprietorships and closely-held corporations, conventionally computed, are split into a capital income component and a labor income component, and these are taxed on a current basis. ${ }^{165}$ The capital income component is calculated by applying a presumptive return (the sum of the nominal interest rate plus an entrepreneurial risk premium) to the value of the gross assets of the business (Norway) or to equity (Finland). ${ }^{166}$

\footnotetext{
${ }^{162}$ As Andersson et al. (1998) point out, the RISK method is not easy to implement.

${ }^{163}$ It is worth noting that the net return on capital is exogenously determined in small open economies. Hence, these taxes (as well as the CT) influence the before-tax return on the marginal investment project that is necessary to provide nonresident investors their fixed after-tax return (unless the marginal investment is financed by debt).

${ }^{164}$ For a detailed description and evaluation of the profit-splitting scheme, see Hagen and Sørensen (1996). This approach avoids most of the deferral and lock-in effects of the tax that other Member States impose on capital gains on substantial holdings. Also, the profit-splitting rules of the source model seem easier to administer than some of the tortuous and arbitrary provisions for the prevention of undertaxation of the self-employed currently on the statute books in countries without a DIT. For a different view, see Sørensen (1994) who has labeled the compulsory profit-splitting rules the Achilles heel of the DIT.

${ }^{165}$ This is referred to as the 'source' model of income-splitting. Under the 'fence' model, in Sweden, labor income retained in the business is taxed at the capital income tax rate. Profits are split, however, upon subsequent withdrawal or when a capital gain is realized on the shares of an active shareholder. The fence model tends to favor the self-employed over wage-earners and produces the familiar lock-in effect.

${ }^{166}$ Basically, the gross method minimizes tax arbitrage and hence complexity, because the presumptive return is applied to a base - i.e. the business's total assets - that is not influenced by the financing structure of the business. The net (equity) method, on the other hand, is more conducive to investment neutrality, because it does not encourage debt-financed investments if the government sets the presumptive rate of return above the going interest rate.
} 
Residual profits are considered as labor income. ${ }^{167}$ The reason for determining capital income first is that the appropriate return on labor is difficult to estimate, because diligence, effort and ingenuity may diverge widely, as may the hourly wage rate relating to various kinds of labor and the number of hours worked. Moreover, if labor income were to be determined first, the marginal PT rate on the profits of the self-employed and active shareholders would exhibit a regressive incidence. Additional earnings would then be taxed at the proportional CT rate instead of the progressive PT rate.

\section{Net Wealth Tax}

Optionally, the progressivity of the burden distribution of the capital income tax can be increased through the net wealth tax, which is levied in Norway, Finland and Sweden. This tax also implies that residents are taxed differentially higher than nonresidents.

\section{(b) Interest Withholding Taxes}

The goal of ensuring single taxation under current DITs, however, is mostly honored in the breach with respect to interest (and royalty) payments to exempt entities, such as pension funds, and foreign debtholders (or suppliers of knowhow). The absence of a withholding tax on interest paid to foreign debtholders leaves opportunities intact for evading or avoiding the CT or DIT on interest income by foreign as well as domestic debtholders. ${ }^{168}$ This hole in the CT bucket can only be plugged by imposing a withholding tax at the CT rate on all interest - in effect, treating interest on a par with dividend income, which is taxed only at

\footnotetext{
${ }^{167}$ Both Finland and Norway mitigate the tax burden on labor-intensive firms, basically by allocating a specified percentage of labor income - 10 percent of the payroll in Finland, 11 percent in Norway - to the capital income component of the DIT.

${ }^{168}$ The following discussion assumes that policy-makers wish to tax interest or, more generally, the normal return to capital. Accordingly, proposals for a cash-flow tax or an allowance for corporate equity (ACE) are not reviewed. Under a cash-flow tax, corporations would be denied a deduction for interest as well as dividends paid (if not already denied), but they would be allowed an immediate write-off of the cost of business assets. As a result, the return on marginal investments, just making a viable economic return, would be exempted. See McLure and Zodrow (1996) for arguments why taxation on cash flow has economic and administrative advantages over a conventional income tax. Under the ACE system, conceived by Boadway and Bruce (1984) but given hands and feet by the IFS Capital Taxes Group (1991), an allowance for corporate equity, equal to the risk-free rate of interest (Bond and Devereux, 1995), in computing taxable profits would be provided. Until recently, a form of ACE was in use in Croatia, where it was called the interest-adjusted income tax (IAIT) (Rose and Wiswesser, 1998). For a discussion of the system and of criticisms leveled against it, see Keen and King (2002). The taxation of new corporate equity in Italy at the lower rate of 19 percent may be said to resemble an ACE-type system. Under the Italian approach, however, debt is still subsidized through the tax system and corporations have a strong incentive to convert old equity into 'new' equity. For a review and evaluation, see Bordignon, Gianninni and Panteghini (2001). Whatever the merits of cash-flow taxation or ACE systems, it should be pointed out that taxes on non-country-specific economic rents would still require tax policy coordination in the EU if location decisions are not to be affected.
} 
the corporate level. Arrangements could then be made under which tax withheld at business level would be creditable in residence Member States (hence, capital income could be taxed at different rates by those Member States). Alternatively, the tax withheld would not be creditable but constitute the final liability in the source state (which would require approximation of tax rates if investment location decisions were not to be distorted).

Final, source-based, withholding taxes on interest would make the DIT equivalent to a comprehensive business income tax (CBIT). This tax, proposed by the US Department of the Treasury (1992), proceeds from the fundamental equivalence between a CT levied at source and an equal-rate PT on corporate earnings with full credit for the underlying CT. Accordingly, no deductions are allowed, at corporate level, for dividends and interest paid to shareholders and debtholders, while these income items are not taxed at the level of the recipients, be they individuals or corporations, exempt entities or nonresidents. This makes the debt-equity distinction irrelevant and greatly reduces the distinction between retained and distributed earnings (depending on the treatment of capital gains). ${ }^{169}$

The CBIT can be introduced while largely maintaining the present rules for determining taxable profits, including those applicable to depreciation and inventory accounting. Exempt entities and nonresidents would be treated the same as resident individuals or corporations. They would not be eligible for a refund of the CBIT, nor would they have to pay any additional CBIT in the form of a withholding tax or otherwise. Corporations receiving CBIT income as dividends or interest would also not be taxed on such income. To ensure that dividends and interest are not paid out of exempt earnings, a compensatory tax (already in place under various imputation systems in the EU) should be levied on exempt income (made available for distribution as dividends or interest). ${ }^{170}$ Capital gains on shares would only be taxed to the extent that they exceed the acquisition cost stepped up by the corporation's retained profits net of the CT. As a point of immediate policy relevance, the introduction of a single sourcebased tax on dividends and interest under CBIT or DIT implies that the parentsubsidiary directive should be welcomed, because it eliminates an undesirable extra layer of tax, but that the draft interest/royalty directive should not be adopted, because it prohibits a desired single layer of tax.

The main problem of the DIT (final) withholding tax on interest and the CBIT is that they would raise capital costs, because the normal return on capital, even if received by exempt entities and nonresidents, would be implicitly taxed. Although this would seem a goal worth pursuing, gradual and concerted action is called for. Caution is advisable because the current tax-induced changes in

\footnotetext{
${ }^{169}$ The CBIT differs from a cash-flow tax in that assets are depreciated over their lifetime, as they would be under a conventional income tax. Hence, the normal return on capital is taxed.

${ }^{170}$ The US Department of the Treasury (1992) advocates imposing the compensatory tax on foreign-source income too, while retaining current foreign tax credit rules. To avoid double taxation, this should not, of course, be done in the EU, where the exemption method would apply to foreign-source income.
} 
corporate financing patterns may, to a large extent, serve to reduce the distortions of real investment and saving decisions. Higher before-tax rates, moreover, would dampen (debt-financed) investment demand. Coordination with the US and Japan would be essential in order to prevent tax-induced capital outflows due to the higher cost of capital in the EU.

\section{(c) Approximation of CT Rates}

The exemption of dividend income at the personal level and the taxation of interest income at source should reduce the need for concerted tax harmonization at the central EU level. The problem of thin capitalization and the lack of external neutrality of the imputation system would be solved. In fact, the schemes for CT-PT integration would become redundant. Manipulation of transfer prices, however, could still affect the allocation of the corporate tax base across Member States. To limit this form of tax arbitrage, a minimum rate, as proposed by the Ruding Committee, would have to be agreed to. Presumably, rate approximation would be easier to achieve following the introduction of DITs and interest withholding taxes.

\section{(d) Common Base Taxation?}

DIT and CBIT would still proceed from the separate-accounting approach in determining the taxable profits of affiliated corporations in different Member States. Provisions for the removal of cross-border obstacles to economic activity and business restructuring, therefore, would still be needed. As pointed out by the European Commission (2001), a comprehensive solution to these problems, if desired, can only be achieved through Common Base Taxation. The advantages of Common Base Taxation with formula apportionment (and its logical conclusion, unitary taxation) are fewer distortions, less tax arbitrage and lower compliance costs. But the path to Common Base Taxation would not be easy. Its introduction would give rise to serious policy-sequencing and transition problems for EU Member States. Accounting conventions and institutional structures would have to be harmonized. All of these problems would be exacerbated by complex technical questions, such as defining a unitary business, choosing the apportionment formula and measuring the factors in the formula. Last but not least, tax autonomy would suffer, although some room for independent policy-making would remain by permitting Member States to choose their own tax rate within an agreed range.

In a recent contribution, McLure and Weiner (2000) make clear that formula apportionment is conceptually inferior to separate accounting if separate accounting can be applied. In contrast with reality, formula apportionment assumes, for instance, that profitability is uniform across related corporations operating in different Member States. Furthermore, the application of uniform 
formulas to all industries, although very different in terms of production technology and financial structures, could create inequities and distortions. Beyond that, the adoption of unitary taxation may complicate relations with nonEU countries.

Furthermore, according to McLure and Weiner (2000), formula apportionment must face the demonstrated reluctance of Member States to cede corporate tax issues to the central level. They believe that substantial variation is likely to remain a permanent feature of CT systems in the EU. In light of this, it is not surprising that these authors stop short of giving a definitive answer to the question of whether it makes policy sense to adopt formula apportionment. Instead, they conclude with what the EU should not do if it decides to adopt formula apportionment. First, if wide variations in tax rates continue to exist, formula apportionment should not be introduced without unitary combination. Secondly, formula apportionment should be limited to the water's edge of the EU and not be applied on a worldwide basis. Thirdly, there should be substantial conformity in definitions of tax bases, apportionment rules, measures of apportionment factors and definitions of a unitary business. Fourthly, the only way to make a move to unitary taxation, if one is to be made, is multilaterally, by all Member States.

\section{(e) A European CT?}

EU-wide unitary taxation will only fully reduce distortions and compliance costs if applied by a joint administration under a common code uniformly interpreted by the European Court of Justice. ${ }^{171}$ Indeed, Common Base Taxation would probably not be possible without these conditions. Accordingly, the logical conclusion of the tax coordination and tax harmonization steps outlined above would be a European CT whose revenue would either be shared by the Member States on the basis of some formula or flow into the EU's budget. A truly European CT, however, would require fundamental changes in the EU's constitution moving it in the direction of a federal (tax) system. For the time being, this seems a bridge too far.

\section{HOW MUCH TAX COORDINATION?}

This section summarizes the main findings of this review and dwells briefly on the question of how much tax coordination is required.

\footnotetext{
${ }^{171}$ Of course, even then it would be important to heed the rule that all capital income should be taxed only once and at a uniform rate.
} 


\section{Summary}

As economic integration within the EU progresses, the interactions between the tax systems of the Member States are of growing importance. In all Member States, tax (and expenditure) systems persuasively influence economic activities. In the EU, the combined tax burden of the Member States is 42.5 percent of the EU's GDP compared with a US tax burden of 29.4 percent. In particular, taxes on labor (including taxes on consumption) are very high - 36 percent of GDP (against 20 percent in the US).

The political tax setting in the EU contains elements of both the 'independent nation state' and the 'federal system.' The three main criteria that may be applied to the design of tax policy in this setting are jurisdiction, distortion and enforcement. Jurisdiction or 'subsidiarity' is central to the Treaty of Maastricht; generally it means that the power to tax rests with the Member States. Distortion, the leitmotif of the Treaty of Rome, implies that taxes should be levied without unduly interfering with trade and investment. The taxes under review can be broadly categorized in taxes on consumption, labor and capital.

\section{(a) Taxes on Consumption}

Generally, the VAT, is very suitable for Member State use. Consumers, and hence the consumption tax base, tend to be rather immobile. Sensitivity to interMember-State rate differences is low. Cross-border shopping diminishes rapidly with the distance that has to be traveled and rate differences are unlikely to affect interstate resource allocation. Furthermore, the VAT is relatively difficult to avoid or evade on account of the interlocking audit trail (for in-state transactions) and reporting checks (for out-of-state transactions) it provides. Administrative duplication arises because firms with EU-wide sales must deal with 15 different VAT administrations.

There are few serious jurisdictional problems under VAT. The tax is levied in the Member State of final sale (a close proxy for consumption). Cross-border shopping attracts a great deal of attention, but in terms of overall impact - on local merchants, manufacturing location decisions and revenue - the phenomenon is not significant. The incentive for cross-border shopping diminishes rapidly with the distance that has to be traveled to buy goods in other Member States. Consequently, rate approximation between Member States seems quite unnecessary. Services - including digitized content transmitted over the Internet, which, not being goods, are classified as services - present a problem, however, because modern technology makes many services both mobile and location-free.

Distortion under the VAT comes mainly from the exemption of healthcare and education, cultural services, immovable property, finance, insurance, and not to forget public sector activities. A strong case can be made, therefore, for taxing these services - at a zero rate perhaps if externalities arise. This would eliminate 
input distortions, put exports on a more neutral footing and induce exempt institutions to keep an eye on cost minimization - the corollary of profit maximization in the marketplace. Contracting-out (privatization) of various inhouse services, such as laundry, cleaning, food preparation and administration, would become more attractive. In eliminating unwarranted exemptions, the EU Member States can learn much from newcomers to the VAT - New Zealand, Canada and Australia. These countries follow best practice by taxing all of the services that are exempt in the EU except residential rents and rental values, finance, insurance and primary education.

Enforcement is made quite an issue by the European Commission which believes in the no-break-in-the-VAT-chain doctrine. Allegedly, the current transitional regime under which cross-border supplies within the EU are zerorated creates a no man's land outside VAT control. Various alternatives, all destination-based, that would not break the VAT chain have been proposed by the European Commission and in the tax literature. The problem with the proposals, however, is that they do not make clear the shortcomings of the deferred payment scheme (called the transitional regime) that is currently in place. By all accounts, the regime works satisfactorily. What should be abolished, however, are the statistical obligations for cross-border supplies within the EU. Following the introduction of the euro, these obligations (not applicable to services, anyway, and meaningless for intercompany transactions) have lost much of their relevance.

Enforcement considerations loom large with respect to the 'sin' taxes: excises on drinking, smoking, driving, polluting and gambling. Cigarettes and alcohol are taxed at widely differing effective rates. Consequently, bootlegging (tax-base snatching) is a serious problem. Further policy and administrative coordination would raise additional excise revenue which could be used to reduce other more distortionary taxes. This does not apply to motor vehicle taxes, which can be tied to taxpayers' residences.

\section{(b) Taxes on Labor}

Distortion, not jurisdiction or enforcement, is the main problem with taxes on labor. Of all markets, the labor market is probably the most distorted in the EU. Low participation and high unemployment are a waste of human potential and national product. Total average and marginal tax rates on labor, represented by the OECD's average production worker (APW), are extremely high. Economic models indicate that switches in the tax burden away from labor to consumption, capital and energy - advocated by the European Commission - hardly affect participation rates, because, in the main, these taxes are also borne by labor. Rather, it is the interaction between taxes, social benefits and labor market regulations that depresses labor supply and demand. There is an 'iron law' that labor market incentives cannot be reconciled with 'adequate' income support 
systems. This suggests that the trade-off between in-work benefits (which creates the poverty trap) and out-of-work replacement rates (which creates the unemployment trap) should be reviewed. This trade-off is acute among lowincome earners, but it is also inherent in many disability and early-retirement schemes.

The main lesson, not new, from this review is that Member States should solve their own labor market problems, including those that arise from the interaction of taxes, social benefits and regulations (another form of taxation). Involvement of the central EU level would most likely exacerbate existing distortions. Another lesson is that the tax system cannot solve and should not be used to cover up the failures of the social security system.

\section{(c) Taxes on Capital}

Jurisdiction (and enforcement) are problematic issues under corporation taxes (CTs). Because tax entitlement is based on the source or territoriality principle, profits must be accounted for separately per Member State. This means that transactions between related firms must be valued on the basis of the arm'slength principle - comparable prices determined in open markets. But the arm'slength principle is not much of a principle if prices cannot be determined at arm's length even if all the facts are known. In theory, there is no answer to the question of where the profits of a pharmaceutical company accrue if a drug is invented in France, produced in Italy and consumed in Spain. Per force, the division of the company's profits must be made arbitrarily. Furthermore, distortions arise because nearly all Member States tax different forms of capital income at widely varying rates. Within Member States, these differences interfere with financing and investment decisions. Debt is favored over equity and institutional investors over individual investors. Between Member States, the differences create production distortions. In addition, various cross-border obstacles to investment and business restructuring exist.

The European Commission (2001) has reviewed a large number of targeted and comprehensive measures to eliminate cross-border obstacles. Targeted remedial measures would extend the scope of the (draft) directives on crossborder dividend, interest and royalty payments, mergers and provisions for loss compensation. Comprehensive measures are designed to remove cross-border obstacles by introducing a single tax base for corporations with cross-border operations (Home State Taxation) or a common tax base for two or more Member States (Common Base Taxation). It is doubtful, however, whether the comprehensive measures would reduce tax distortion, arbitrage and complexity. According to one astute observer (Mintz, 2002), the proposals are fraught with problems, and a serious question arises as to whether Home State Taxation or Common Base Taxation are worth the effort. 
Sijbren Cnossen

Accordingly, an alternative approach to coordinating capital income taxes in the EU is sketched. The centerpiece of this approach is a dual income tax (DIT) as found in the Nordic countries which taxes all capital income at a single, uniform rate, i.e. the CT rate. The DIT seems an appropriate model for the EU Member States for three reasons. First, the DIT eliminates the distortions and arbitrage problems that attend the current differential taxation of capital income across sectors, assets and modes of finance. Generally, double taxation of distributed and retained profits is (or can be) avoided. Secondly, the DIT does not raise capital costs outright, because interest paid to tax-exempts and nonresidents is not taxed. Yet the DIT leaves the door open to taxing the normal return to capital more fully through EU-wide and international tax policy coordination. Thirdly, by separating capital income from labor income, the capital income tax rate under the DIT is not made hostage to the (higher) tax rate on labor income. Hence, the capital income tax rate becomes an additional tax policy instrument for governments, because the rate can be lowered (or raised) more easily in response to growing tax mobility and tax competition (or tax coordination).

Under the DIT, full neutrality will not be achieved unless a withholding tax is imposed on interest (and royalties) at source. This would convert the DIT into a comprehensive business income tax (CBIT) if the withholding tax were not creditable in residence countries. This source-based tax would require tax rate approximation if investment location decisions were not to be distorted. ${ }^{172}$ Agreement on a (minimum) CT rate would reduce the incentive for profitshifting to low-tax jurisdictions. However, such a tax would leave separate accounting and the attendant cross-border obstacles to economic activity intact. The tax costs of separate accounting can only be reduced through the introduction of Common Base Taxation on an EU-wide basis accompanied by a system of formula apportionment (with unitary combination). The adoption of a truly European CT whose revenue would flow into the EU's budget will have to wait until the EU acquires the legitimacy and the power to tax.

\section{How Much Tax Coordination?}

This summary has highlighted various issues regarding jurisdiction, distortion and enforcement but has not indicated the extent to which Member States should coordinate their tax systems. This is because there are important trade-offs between efficiency and subsidiarity. The economist can highlight these trade-offs and estimate the costs of alternative courses of action, but the body politic has to decide on the exact nature and extent of the trade-offs. The following prominent strands of thought illuminate the debate.

\footnotetext{
${ }^{172}$ Paraphrasing Slemrod (1995), an EU featuring equal-rate source-based capital income taxes would be more efficient than an EU featuring fully enforced residence-based taxes (if feasible of implementation) only, because the cost of enforcement is lower for the system of source-based taxes.
} 
To begin with, the choice of the trade-offs depends on the route to tax integration that is followed. As Kay (1993) has pointed out, there is integration through harmonization and integration through competition. In the first of these approaches - which he calls the Bismarckian approach - the creation of the internal market requires prior alignment of the tax policies and practices of the Member States. Under the second - the Jeffersonian approach - the mechanism of choice is to promote integration at all deliberate speed and to let the consequences for the tax rules follow from that. In essence, the choice is between prescription and adaptation, a choice that has deep historic roots in Europe.

In the spirit of the Jeffersonian approach, Bird (1989) has noted that there are two related but quite separate dimensions of integration, the economic and the political (as expressed by, among others, tax integration). His review of the actual situation in six federations and the [EU] common market shows that there is no single continuum between the economic and the political or tax dimension. In practice, economic union can exist quite separately without much political or tax integration. As he states provocatively, 'economic union is not a degenerate case of federalism'. Further, he continues: '[j]ust as in federations, identical tax systems may be neither necessary nor desirable in a common market in which member states have different policy objectives and different economic conditions'. In his view, the 'differential' approach instead of the 'equalization' approach seems most appropriate in principle.

Based upon a careful examination of the fiscal history of five confederations, Mihajek (1998) argues, furthermore, that political integration is not a necessary consequence of monetary integration. Confederations have the advantage that they enable Member States to reap most of the benefits of economic integration, while still allowing them to exercise independent powers in key areas of policymaking. Applied to the EU, there would be little role for an allocation function of the center in an economic union. ${ }^{173}$ Furthermore, the redistribution function would be limited to regional aid made necessary on account of the limited effective mobility of labor. The stabilization function, finally, can be exercised through a cooperative approach that establishes rules limiting the size of Member States' budget deficits and government debt. ${ }^{174}$

The contrast between tax harmonization, which may reduce economic distortions, and tax competition, which may reduce political distortions, is explored by Frey and Eichenberger (1996). The authors argue that the strong bias in favor of tax harmonization weakens resistance against increases in taxation because 'exit does not help and protest (voice) is less attractive because

\footnotetext{
${ }^{173}$ Mention should be made, however, of the wide range of regulatory powers of the European Union concerning technical, environmental, safety and health standards which, exercised by the Member States themselves, could all be used to interfere with free trade and competition.

${ }^{174}$ Implicitly, this assumes that economic integration limits the occurrence and size of asymmetric economic shocks.
} 


\section{Sijbren Cnossen}

everyone is affected equally ...'. To combat the tax harmonization cartel, the 'rules of the game' should be changed, in their view, through the wider use of popular referendums and the introduction of functional, overlapping, competing jurisdictions. An incidental, if welcome, side effect of these new rules would be that economic distortions would also be reduced. Or, in McLure's (1986) words, what's good for the private goose should also be good for the public gander.

A common thread in these findings and analyses is that a gradualist approach should be preferred over an holistic approach. As the earlier US political experience indicated, blueprints are divisive, primarily because they are not the outcome of a process in which all parties have participated in an open and wellinformed manner. Accordingly, great weight should be attached to devising processes in which participants have an equal chance of influencing the results, rather than to the results themselves. Tax-policy-makers should be advised to grapple for incremental changes in existing fiscal institutions that are acceptable, workable and an improvement. This means that tax coordination will continue to be a slow, arduous process - two steps forward, one step back. But this is no reason for despair (in fact, it is the way we dance). The EU has often been compared to a tortoise that never seems to move but that has covered a remarkable amount of ground since its birth in the late 1950s.

\section{REFERENCES}

Adema, W., 1999, Labour Market and Social Policy, Net Social Expenditure, OECD Occasional Papers no. 39, Paris: Organization for Economic Cooperation and Development.

Agell, J., P. Englund and J. Södersten, 1996, Tax Reform of the Century: The Swedish Experiment, National Tax Journal, 49.

Agha, A. and J. Haughton, 1996, Designing VAT Systems: Some Efficiency Considerations, Review of Economics and Statistics, 78.

Andersson, K., V. Kanniainen, J. Södersten and P.B. Sørensen, 1998, Corporate Tax Policy in the Nordic Countries, in P.B. Sørensen, ed., Tax Policy in the Nordic Countries, New York, NY: MacMillan.

Auerbach, A., J.A. Frenkel and A. Razin, 1996, Equivalence Relations in International Taxation, in M.I. Blejer and T. Ter-Minassian, eds, Macroeconomic Dimensions of Public Finance: Essays in Honour of Vito Tanzi, London: Routledge.

Auerbach, A. and L.J. Kotlikoff, 1987, Dynamic Fiscal Policy, Cambridge: Cambridge University Press.

Aujean, M., P. Jenkins and S. Poddar, 1999, A New Approach to Public Sector Bodies, International VAT Monitor, 10/4.

Australian Society of CPAs, 1998, Tax Reform in New Zealand - The Shape of Things to Come in Australia?, Discussion Paper (May).

Baker and McKenzie, 2001, Survey of the Effective Tax Burden in the European Union, Amsterdam: International Bureau of Fiscal Documentation.

Barde, J-P. and N-A. Braathen, 2002, Environmentally Related Levies, paper presented at a conference on Excise Tax Policy and Administration, The Hague. 
Bartelsman, E.L. and R.M.W.J. Beetsma, 2000, Why Pay More? Corporate Income Tax Avoidance through Transfer Pricing in OECD Countries, CESifo Working Paper no. 324, Munich.

Bird, R.M., 1989, Tax Harmonization in Federations and Common Markets, in M. Neumann and K.W. Roskamp, eds, Public Finance and Performance of Enterprises, Detroit, MI: Wayne State University Press.

Bird, R.M. and P-P. Gendron, 1998, Dual VATs and Cross-Border Trade: Two Problems, One Solution?, International Tax and Public Finance, 5.

Bird, R.M. and P-P. Gendron, 2000, CVAT, VIVAT, Dual VAT: Vertical 'Sharing' and Interstate Trade, International Tax and Public Finance, 7.

Bird, R.M. and P-P. Gendron, 2001, VATs in Federal Countries: International Experience and Emerging Possibilities, Bulletin for International Fiscal Documentation (July).

Bird, R.M. and C.E. McLure, Jr., 1990, The Personal Income Taxes in an Interdependent World, in S. Cnossen and R.M. Bird, eds, The Personal Income Tax: Phoenix from the Ashes?, Amsterdam: North-Holland.

Boadway, R., 2001, Tax Systems in Federations and Economic Unions, paper prepared for the Research Centre for Economic Policy (OCFEB) conference on Tax Policy in the European Union, The Hague.

Boadway, R. and N. Bruce, 1984, A General Proposition on the Design of a Neutral Business Tax, Journal of Public Economics, 24.

Bode, E., C. Krieger-Boden and K. Lammers, 1994, Cross-Border Activities, Taxation and the European Single Market, Kiel: Institut für Weltwirtschaft.

Bond, S.R. and M.P. Devereux, 1995, On the Design of a Neutral Business Tax under Uncertainty, Journal of Public Economics, 58.

Bordignon, M., S. Gianninni and P. Panteghini, 2001, Reforming Business Taxation: Lessons from Italy?, International Tax and Public Finance, 8.

Bovenberg, A.L., 1994, Destination- and Origin-Based Taxation under International Capital Mobility, International Tax and Public Finance, 1.

Bovenberg, A.L., 1995, Environmental Taxation and Employment, De Economist, 143/2.

Bovenberg, A.L., 1996, Comment on the Paper by Bernd Genser and Andreas Haufler, in R. Holzmann, ed., Maastricht: Monetary Constitution without a Fiscal Constitution?, Saarbrücken: Europa Institut.

Bovenberg, A.L., 1999, Green Tax Reforms and the Double Dividend: An Updated Reader's Guide, International Tax and Public Finance, 6/3.

Bovenberg, A.L. and S. Cnossen, eds, 1995, Public Economics and the Environment in an Imperfect World, Boston, MA: Kluwer Academic Publishers.

Bovenberg, A.L., S. Cnossen and R.A. de Mooij, 2002, Hoe harmoniseren we de vennootschapsbelasting: rechtsom of linksom?, Weekblad Fiscaal Recht, 131/6465 (January 24).

Bovenberg, A.L. and J.P. Horne, 1992, Taxes on Commodities: A Survey, in G. Kopits, ed., Tax Harmonization in the European Community: Policy Issues and Analysis, Washington, DC: International Monetary Fund.

Bovenberg, A.L. and H. ter Rele, 1998, Reforming Dutch Capital Taxation: An Analysis of Incentives to Save and Invest, CPB Research Memorandum no. 142, The Hague.

Bradford, D.F., 1986, Untangling the Income Tax, Cambridge, MA: Harvard University Press for the Committee for Economic Development. 
Sijbren Cnossen

Bradford, D.F., 1996, Treatment of Financial Services under Income and Consumption Taxes, in H.J. Aaron and W.G. Gale, eds, Economic Effects of Fundamental Tax Reform, Washington, DC: Brookings Institution Press.

Bratton, W. and J. McCahery, 2001, Tax Coordination and Tax Competition in the European Union: Evaluating the Code of Conduct on Business Taxation, Common Market Law Review, 38.

Buijink, W., B. Jansen and Y. Schols, 1999, Corporate Effective Tax Rates in the European Union, Report Commissioned by the Ministry of Finance in the Netherlands, Maastricht Accounting and Auditing Research and Education Center (April).

Bygrå, S., C.Y. Hansen, K. Rystad and S. Søltoft, 1987, Danish-German Border Shopping and Its Price Sensitivity, Aabenraa: Institut for Graenseregionsforskning.

Carter Commission, 1966, Royal Commission on Taxation, Report, Ottawa: Queen's Printer.

Cnossen, S., 1981, Specific Issues in Excise Taxation: The Alcohol Problem, in K.W. Roskamp and F. Forte, eds, Reforms of Tax Systems, Detroit, MI: Wayne State University Press.

Cnossen, S., 1983, Harmonization of Indirect Taxes in the EEC, in C.E. McLure, Jr., ed., Tax Assignment in Federal Countries, Canberra: ANU Press.

Cnossen, S., 1984, Corporation Taxes in OECD Member Countries, Bulletin for International Fiscal Documentation (November).

Cnossen, S., 1987, Tax Structure Developments, in S. Cnossen, ed., Tax Coordination in the European Community, Deventer: Kluwer.

Cnossen, S., 1990, The Case for Tax Diversity in the European Community, European Economic Review, 4.

Cnossen, S., 1993, What Kind of Corporation Tax?, Bulletin for International Fiscal Documentation (January).

Cnossen, S., 1994, Administrative and Compliance Costs of the VAT: A Review of the Evidence, Tax Notes, 63.

Cnossen, S., 1996, The Treatment of Immovable Property, in V. Thuronyi, ed., Tax Law Design and Drafting, Washington, DC: International Monetary Fund.

Cnossen, S., 1996a, Company Taxes in the European Union: Criteria and Options for Reform, Fiscal Studies, 17/4.

Cnossen, S., 1997, The Role of the Corporation Tax in OECD Member Countries, in J. Head and R. Krever, eds, Company Tax Systems, Melbourne: Fiscal Publications.

Cnossen, S., 1998, Global Trends and Issues in Value-Added Taxation, International Tax and Public Finance, 5.

Cnossen, S., 1999, What Rate Structure for Australia's VAT? The OECD Experience, Tax Notes International (May 24).

Cnossen, S., 1999a, VAT Treatment of Financial Services, in G. Lindencrona, S-O. Lodin and B. Wiman, eds, International Studies in Taxation: Law and Economics - Liber Amicorum Leif Mutén, Deventer: Kluwer.

Cnossen, S., 1999b, Taxing Capital Income in the Nordic Countries: A Model for the European Union?, Finanzarchiv, 56/1. Also published in S. Cnossen, ed., 2000, Capital Income Taxation in the European Union: Issues and Options for Reform, Oxford: Oxford University Press.

Cnossen, S. and A.L. Bovenberg, 1997, Company Tax Harmonization in the European Union: Some Further Thoughts on the Ruding Committee Report, in M.I. Blejer and T. Ter-Minassian, eds, Macroeconomic Dimensions of Public Finance: Essays in Honour of Vito Tanzi, London: Routledge. 
Cnossen, S. and A.L. Bovenberg, 2001, Fundamental Tax Reform in the Netherlands, International Tax and Public Finance, 8/4.

Cnossen, S. and M. Smart, 2002, Taxation of Tobacco, paper presented at a conference on Excise Tax Policy and Administration, The Hague.

Devereux, M.P., 1992, The Ruding Committee: An Economic Assessment, Fiscal Studies, 13/2.

Devereux, M.P. and H. Freeman, 1991, A General Neutral Profits Tax, Fiscal Studies, 12/3.

Devereux, M.P. and R. Griffith, 1998, Taxes and the Location of Production: Evidence from a Panel of US Multinationals, Journal of Public Economics, 68.

Devereux, M.P. and R. Griffith, 2001, Summary of the 'Devereux and Griffith' Economic Model and Measures of Effective Tax Rates, Annex A of European Commission, Company Taxation in the Internal Market, $\mathrm{COM}(2001) 582$ final, Brussels.

Diamond, P. and J. Mirrlees, 1971, Optimal Taxation and Public Production I: Production Efficiency, American Economic Review, 61.

Disney, R., 2000, The Impact of Tax and Welfare Policies on Employment and Unemployment in OECD Countries, IMF Working Paper no. 00/164, International Monetary Fund, Washington, DC.

Dufwenberg, M., H. Koskenkylä and J. Södersten, 1994, Manufacturing Investment and Taxation in the Nordic Countries, Scandinavian Journal of Economics, 96.

Easson, A., 1992, Harmonization of Direct Taxation in the European Community: From Neumark to Ruding, Canadian Tax Journal, 40.

Ebrill, L., M. Keen, J-P. Bodin and V. Summers, 2001, The Modern VAT, Washington, DC: International Monetary Fund.

Edwards, J.S.S. and M.J. Keen, 1996, Tax Competition and Leviathan, European Economic Review, 40.

Eissa, N. and J.B. Liebman, 1996, Labor Supply Responses to the Earned Income Tax Credit, Quarterly Journal of Economics, 111 (May).

European Commission, 1985, Completing the Internal Market, White Paper from the Commission to the European Council, Brussels.

European Commission, 1986, Elimination of Distortions of Competition of a Fiscal Nature in the Transport of Goods by Road: Study of Vehicle Taxes, Fuel Taxes, and Road Tolls, COM(86) 750 final, Brussels.

European Commission, 1989, Completion of the Internal Market and Approximation of Indirect Taxes, COM(89) 260 final, Brussels.

European Commission, 1989a, Proposal for a Council Directive on a Common System of Withholding Tax on Interest Income, COM(89) 60/3/Revision final, Brussels.

European Commission, 1991, A Community Strategy to Limit Carbon Dioxide Emissions and Improve Energy Efficiency, SEC(91) 1744 final, Brussels.

European Commission, 1996, Taxation in the European Union: Report on the Development of Tax Systems, COM(96) 546 final (October 22), Brussels.

European Commission, 1996a, A Common System of VAT: A Programme for the Single Market, COM 328(96) final, Brussels.

European Commission, 1997, Supplementary Pensions in the European Union, Green Paper, D-G $\mathrm{XV}$, June 5.

European Commission, 1998, Electronic Commerce and Indirect Taxation, COM 374, Brussels.

European Commission, 2000, Strategy to Improve the Operation of the VAT System within the Context of the Internal Market, COM 324, Brussels. 
Sijbren Cnossen

European Commission, 2001, Company Taxation in the Internal Market, COM(2001) 582 final, Brussels.

European Commission, undated, Value-Added Tax: A Study of the Methods of Taxing Financial Institutions, Brussels.

European Parliament, 2001, Tax Co-Ordination in the EU - The Latest Position, Working Paper, Directorate-General for Research, ECON 128 EN.

Feldstein, M. and P. Krugman, 1990, International Trade Effects of Value-Added Taxation, in A. Razin and J. Slemrod, eds, Taxation in the Global Economy, Chicago, IL: Chicago University Press.

Fitz Gerald, J., J. Johnston and J. Williams, 1995, Indirect Tax Distortions in a Europe of Shopkeepers, Working Paper no. 56, Economic and Social Research Institute, Dublin.

Fitz Gerald, J.D., T. Quinn, B. Whelan and J. Williams, 1988, An Analysis of Cross-Border Shopping, Paper no. 137, Economic and Social Research Institute, Dublin.

Frey, B. and R. Eichenberger, 1996, To Harmonize or to Compete? That's Not the Question, Journal of Public Economics, 60.

Fullerton, D., 1986, The Use of Effective Tax Rates in Tax Policy, National Tax Journal, 39.

Gammie, M., 1992, The Harmonisation of Corporate Income Taxes in Europe: The Ruding Committee Report, Fiscal Studies, 13/2.

Gammie, M., 1992a, Corporate Tax Harmonization: An 'ACE' Proposal, European Taxation, 31.

Genser, B., 1996, A Generalized Equivalence Property of Mixed International VAT Regimes, Scandinavian Journal of Economics, 98.

Goolsbee, A. and E.L. Maydew, 2000, Coveting Thy Neighbor's Manufacturing: The Dilemma of State Income Apportionment, Journal of Public Economics, 75/1.

Gordon, R., 2000, Taxation of Capital Income vs. Labour Income: An Overview, in S. Cnossen, ed., Taxing Capital Income in the European Union: Issues and Options for Reform, Oxford: Oxford University Press.

Gorter, J. and R. de Mooij, 2001, Capital Income Taxation in Europe: Trends and Trade-Offs, The Hague: SDU Uitgevers.

Gorter, J. and A. Parikh, 2000, How Mobile Is Capital within the EU?, CPB Research Memorandum no. 172, The Hague.

Goulder, L.H., 1995, Environmental Taxation and the Double Dividend: A Reader's Guide, International Tax and Public Finance, $2 / 2$.

Gravelle, J., 1994, The Economic Effects of Taxing Capital Income, Cambridge, MA: MIT Press.

Hagen, K.P. and P.B. Sørensen, 1996, Taxation of the Self-Employed: Taxation Principles and Tax Reforms in the Nordic Countries, in S. Cnossen, ed., Towards a Dual Income Tax? Scandinavian and Austrian Experiences, Rotterdam: Kluwer. A revised version is included in P.B. Sørensen, ed., 1998, Tax Policy in the Nordic Countries, New York, NY: MacMillan.

Hall, R.E. and A. Rabushka, 1995, The Flat Tax, $2^{\text {nd }}$ edn, Stanford, CA: Hoover Institution Press.

Harberger, A., 1990, The Uniform-Tax Controversy, in V. Tanzi, ed., Public Finance, Trade, and Development, Detroit, MI: Wayne State University Press.

Haveman, R., 1996, Reducing Poverty while Increasing Employment: A Primer on Alternative Strategies and a Blueprint, OECD Economic Studies no. 26, Paris: Organization for Economic Cooperation and Development.

Head, J.J., 1996, Company Tax Structure and Company Tax Incidence, International Tax and Public Finance, 3.

Hemming, R. and J.A. Kay, 1981, The United Kingdom, in H.J. Aaron, ed., The Value-Added Tax: Lessons from Europe, Washington, DC: Brookings Institution. 
Hines, J.R., 1999, Lessons from Behavioural Responses to International Taxation, National Tax Journal, 42.

Hoel, M., 1991, Union Wage Policy: The Importance of Labour Mobility and the Degree of Centralization, Economica, 58 (May).

Horst, T., 1980, A Note on the International Taxation of Interest Income, Quarterly Journal of Economics, 94 (June).

Huizinga, H., 1994, International Interest Withholding Taxation: Prospects for a Common European Policy, International Tax and Public Finance, 1.

Hutton, J.P. and A. Ruocco, 1999, Tax Reform and Employment in Europe, International Tax and Public Finance, 6/3.

IFS Capital Taxes Group, 1989, Neutrality in the Taxation of Savings: An Extended Role for PEPs, IFS Commentary no. 17, London: Institute for Fiscal Studies.

IFS Capital Taxes Group, 1991, Equity for Companies: A Corporation Tax for the 1990s, IFS Commentary no. 26, London: Institute for Fiscal Studies.

International Bureau of Fiscal Documentation, European Taxation, Amsterdam, loose-leaf.

International Bureau of Fiscal Documentation, Value Added Taxes in Europe, Amsterdam, looseleaf.

Irish Commission on Taxation, 1984, Third Report: Indirect Taxation, Dublin: Stationery Office.

Jansen Committee, 1963, General Report of the Sub-Groups A, B and C, in The EEC Reports on Tax Harmonization, Amsterdam: International Bureau of Fiscal Documentation.

Kanbur, R. and M. Keen, 1993, Jeux sans Frontières: Tax Competition and Tax Coordination when Countries Differ in Size, American Economic Review, 63.

Kay, J., 1993, Taxation Policy and Economic Integration, in A. Knoester, ed., Taxation in the United States and Europe: Theory and Practice, New York, NY: St Martin's Press.

Keen, M., 1993, The Welfare Economics of Tax Coordination in the European Community: A Survey, Fiscal Studies, 14/2.

Keen, M. and J. King, 2002, The Croatian Profit Tax: An ACE in Practice, Fiscal Studies, 23(3).

Keen, M. and S. Smith, 1996, The Future of Value Added Tax in the European Union, Economic Policy, 23 (October).

Keen, M. and S. Smith, 1999, Viva VIVAT!, International Tax and Public Finance, 6.

Kehoe, P.J., 1989, Policy Cooperation among Benevolent Governments May Be Undesirable, Review of Economic Studies, 56.

King, M.A. and D. Fullerton, 1984, The Taxation of Income from Capital, Chicago, IL: University of Chicago Press.

Lee, C., M. Pearson and S. Smith, 1988, Fiscal Harmonisation: An Analysis of the European Commission's Proposals, IFS Report Series no. 28, London: Institute for Fiscal Studies.

Lockwood, B. and A. Manning, 1993, Wage Setting and the Tax System: Theory and Evidence from the United Kingdom, Journal of Public Economics, 52.

Lockwood, B., D. de Meza and G. Myles, 1994, When Are Destination and Origin Regimes Equivalent?, International Tax and Public Finance, 1.

Manning, W.G., E.B. Keller, J.P. Newhouse, E.M. Sloss and J. Wasserman, 1989, The Taxes of Sin: Do Smokers and Drinkers Pay Their Way?, Journal of the American Medical Association, 261

Martinez-Mongay, C., 2000, ECFIN's Effective Tax Rates, Properties and Comparisons with Other Tax Indicators, Economic Paper no. 146, Brussels: European Commission, Directorate for Economic and Financial Affairs. 
Sijbren Cnossen

McLure, C.E., Jr., 1979, Must Corporate Income Be Taxed Twice?, Washington, DC: Brookings Institution.

McLure, C.E., Jr., 1986, Tax Competition: Is What's Good for the Private Goose Also Good for the Public Gander?, National Tax Journal, 39.

McLure, C.E., Jr., 1992, Coordinating Business Taxation in the Single European Market: The Ruding Committee Report, EC Tax Review, 1.

McLure, C.E., Jr., 1992a, Substituting Consumption-Based Direct Taxation for Income Taxes as the International Norm, National Tax Journal, 45.

McLure, C.E., Jr., 2000, Implementing Subnational Value Added Taxes on Internal Trade: The Compensating VAT (CVAT), International Tax and Public Finance, 7.

McLure, C.E., Jr., 2001, Tax Assignment and Subnational Fiscal Autonomy, Bulletin for International Fiscal Documentation (December).

McLure, C.E., Jr. and J.M. Weiner, 2000, Deciding Whether the European Union Should Adopt Formula Apportionment of Company Income, in S. Cnossen, ed., Taxing Capital Income in the European Union: Issues and Options for Reform, Oxford: Oxford University Press.

McLure, C.E., Jr. and G.R. Zodrow, 1996, A Hybrid Consumption-Based Direct Tax for Bolivia, International Tax and Public Finance, 3.

Meade, J.E., 1978, The Structure and Reform of Direct Taxation, London: George Allen \& Unwin for The Institute for Fiscal Studies.

Mendoza, E.G., A. Razin and L.L. Tesar, 1994, Effective Tax Rates in Macroeconomics, CrossCountry Estimates of Tax Rates on Factor Incomes and Consumption, Journal of Monetary Economics, 34/3.

Messere, K., 1993, Tax Policy in OECD Countries: Choices and Conflicts, Amsterdam: IBFD Publications.

Messere, K., ed., 1998, The Tax System in Industrialized Countries, Oxford: Oxford University Press.

Mieszkowski, P. and R.A. Musgrave, 1999, Federalism, Grants, and Fiscal Equalization, National Tax Journal, 52.

Mihajek, D., 1998, Theory and Practice of Confederate Finances, in P.B. Sørensen, ed., Public Finance in a Changing World, London: Macmillan Press.

Minford, P., 1996, Unemployment in the OECD and Its Remedies, in D.J. Snower and G. de la Dehesa, eds, Unemployment Policy: Government Options for the Labour Market, Cambridge: Cambridge University Press.

Mintz, J.M., 2002, European Company Tax Reform: Prospects for the Future, CESifo Forum, 3/1.

Mogensen, T., 2002, Excise Duty Tables, Brussels: European Commission.

Mooij, de, R.A. and S. Ederveen, 2001, Taxation and Foreign Direct Investment: A Synthesis of Empirical Research, CPB Discussion Paper no. 3, The Hague.

Mueller, D.C., ed., 1997, Perspectives on Public Choice: A Handbook, New York, NY: Cambridge University Press.

Musgrave, R.A., 1969, Fiscal Systems, New Haven, CT: Yale University Press.

Musgrave, R.A., 1983, Who Should Tax, Where, and What?, in C.E. McLure, Jr., ed., Tax Assignment in Federal Countries, Canberra: ANU Press.

Musgrave, R.A. and P.B. Musgrave, 1984, Public Finance in Theory and Practice, $4^{\text {th }}$ edn, New York, NY: McGraw-Hill.

Neumark Committee, 1963, Report of the Fiscal and Financial Committee, in EEC Reports on Tax Harmonization, Amsterdam: International Bureau of Fiscal Documentation. 
Newbery, D.M., 2002, Road User and Congestion Charges, paper presented at a conference on Excise Tax Policy and Administration, The Hague.

Nickell, S.J., 1997, Unemployment and Labor Market Rigidities: Europe versus North America, Journal of Economic Perspectives, 11 (Summer).

Nickell, S.J. and B. Bell, 1996, Would Cutting Payroll Taxes on the Unskilled Have a Significant Impact on Unemployment?, in D.J. Snower and G. de la Dehesa, eds, Unemployment Policy: Government Options for the Labour Market, Cambridge: Cambridge University Press.

Nicodème, G., 2001, Computing Effective Corporate Tax Rates: Comparisons and Results, Economic Paper no. 153, Brussels: European Commission, Directorate General for Economic and Financial Affairs.

OECD, 1988, Taxing Consumption, Paris.

OECD, 1991, Taxing Profits in a Global Economy: Domestic and International Issues, Paris.

OECD, 1995, The OECD's Jobs Study, Taxation, Employment and Unemployment, Paris.

OECD, 2000, The OECD Employment Outlook, Paris.

OECD, 2000a, Average Effective Tax Rates on Capital, Labour, and Consumption, Working Paper no. 258, Economics Department, OECD, Paris.

OECD, 2001, Revenue Statistics 1965-2000, Paris.

OECD, 2001a, The OECD Employment Outlook, Paris.

OECD, 2001b, Taxing Wages 1999-2000, Paris.

Owens, J., 1993, Globalisation: The Implications for Tax Policies, Fiscal Studies, 14/3.

Pearson, M. and S. Smith, 1991, The European Carbon Tax: An Assessment of the European Commission's Proposal, London: Institute for Fiscal Studies.

Pencavel, J., 1986, Labor Supply of Men: A Survey, in O. Ashenfelter and R. Layard, eds, Handbook of Labor Economics, vol. 1, Amsterdam: North-Holland.

Ploeg, van der, F., 1998, Unemployment and Public Finance in Europe, in P.B. Sørensen, ed., Public Finance in a Changing World, London: Macmillan Press.

Poddar, S. and M. English, 1997, Taxation of Financial Services under a Value-Added Tax: Applying the Cash-Flow Method, National Tax Journal, 50.

Poterba, J.M., 1993, Global Warming: A Public Finance Perspective, Journal of Economic Perspectives, 7.

Poterba, J.M. and L.H. Summers, 1985, The Economic Effects of Dividend Taxation, in E. Altman and M. Subrahmanyam, eds, Recent Advances in Corporate Finance, Homewood, IL: Irwin.

Robson, P., 1998, The Economics of International Integration, $4^{\text {th }}$ edn, London: Routledge.

Rose, M. and R. Wiswesser, 1998, Tax Reform in Transition Economies: Experiences from the Croatian Tax Reform Process of the 1990s, in P.B. Sørensen, ed., Public Finance in a Changing World, London: Macmillan Press.

Ruding Committee, 1992, Conclusions and Recommendations of the Committee of Independent Experts on Company Taxation, Luxembourg: Commission of the European Communities.

Sandford, C.T., ed., 1995, Tax Compliance Costs: Measurement and Policy, Bath: Fiscal Publications.

Sandford, C.T., M.T. Godwin and P.J. Hardwick, 1989, Administrative and Compliance Costs, Bath: Fiscal Publications.

Scholz, J.K., 1996, In-Work Benefits in the United States: The Earned Income Tax Credit, Economic Journal, 106 (January).

Shibata, H., 1967, The Theory of Economic Unions, in C.S. Shoup, ed., Fiscal Harmonization in Common Markets, vol. 1-2, New York, NY: Columbia University Press.

Sinn, H-W., 1985, Capital Income Taxation and Resource Allocation, Amsterdam: North-Holland. 
Sijbren Cnossen

Sinn, H-W., 1991, Taxation and the Cost of Capital: The 'Old' View, the 'New' View and Another 'View', in D.F. Bradford, ed., Tax Policy and the Economy, 5, Cambridge, MA: MIT Press.

Skall Matmomsen Slopas?, 1983, Stockholm, SOU 54.

Slemrod, J.B., 1995, Free Trade Taxation and Protectionist Taxation, International Tax and Public Finance, 2.

Slemrod, J.B., 1995a, Comment on V. Tanzi, Taxation in an Integrating World, in V. Tanzi, Taxation in an Integrating World, Washington, DC: Brookings Institution.

Smith, A., 1776, The Wealth of Nations, ed. by E. Cannan, London: Methuen.

Smith, R.S., 1987, Motor Vehicle Tax Harmonization, in S. Cnossen, ed., Tax Coordination in the European Community, Deventer: Kluwer.

Smith, S., 1993, 'Subsidiarity' and the Co-Ordination of Indirect Taxes in the European Community, Oxford Review of Economic Policy, 9.

Smith, S., 1997, The Definitive Regime for VAT, IFS Commentary no. 63, London: Institute for Fiscal Studies.

Sørensen, P.B., 1994, From the Global Income Tax to the Dual Income Tax: Recent Tax Reforms in the Nordic Countries, International Tax and Public Finance, 1.

Sørensen, P.B., 1994a, Some Old and New Issues in the Theory of Corporate Income Taxation, Finanzarchiv, N.F. 51.

Sørensen, P.B., 1995, Changing Views on the Corporate Income Tax, National Tax Journal, 48.

Sørensen, P.B., 1997, Public Finance Solutions to the European Unemployment Problem?, Economic Policy (October).

Sørensen, P.B., ed., 1998, Tax Policy in the Nordic Countries, New York, NY: Macmillan.

Sørensen, P.B., 2001, The Case for International Tax Co-Ordination Reconsidered, Economic Policy, 31.

Sørensen, P.B., forthcoming, Tax Coordination in the European Union: What Are the Issues?, Swedish Economic Policy Review.

Stiglitz, J.E., 1976, The Corporation Tax, Journal of Public Economics, 5.

Tait, A.A., 1991, Value Added Taxation: Administrative and Policy Issues, IMF Occasional Paper no. 88, Washington, DC: International Monetary Fund.

Tanzi, V., 1995, Taxation in an Integrating World, Washington, DC: Brookings Institution.

Tinbergen Committee, 1953, Report on Problems Raised by the Different Turnover Tax Systems Applied within the Common Market, High Authority of the European Coal and Steel Community.

US Congressional Budget Office, 1992, Effects of Adopting a Value-Added Tax, Washington, DC.

US Department of the Treasury, 1979, Blueprints for Basic Tax Reform, Washington, DC: US Government Printing Office.

US Department of the Treasury, 1992, Integration of the Individual and Corporate Tax Systems: Taxing Business Income Once, Washington, DC: US Government Printing Office.

US Department of the Treasury, 2001, The Deferral of Income Earned through U.S. Controlled Foreign Corporations: A Policy Study, Washington, DC: Office of Tax Policy.

Vanistendael, F., 1992, Comments on the Ruding Committee Report, EC Tax Review, 1.

Versano, R., 2000, Subnational Taxation and the Treatment of Interstate Trade in Brazil: Problems and a Proposed Solution, in S.J. Burki and G. Peary, eds, Decentralization and Accountability of the Public Sector, Washington, DC: World Bank.

Verwaal, E. and S. Cnossen, 2002, Europe's New Border Taxes, Journal of Common Market Studies, 40/2. 
Tax Policy in the European Union

Volkerink, B., 2001, Deficits and Taxes: Essays on the Political Economy of Fiscal Policy, Ridderkerk: Labyrint Publication.

Webber, C. and A. Wildavsky, 1986, A History of Taxation and Expenditure in the Western World, New York, NY: Simon and Schuster.

Weiner, J.M., 2002, Formulary Apportionment and the Future of Company Taxation in the European Union, CESifo Forum, 3/1.

Wheare, K.C., 1963, Federal Government, $4^{\text {th }}$ edn, London: Royal Institute of International Affairs.

Whitehouse, E., 1996, Designing and Implementing In-Work Benefits, Economic Journal, 106 (January).

Zodrow, G.R., 1991, On the 'Traditional' and 'New' Views of Dividend Taxation, National Tax Journal, 44. 